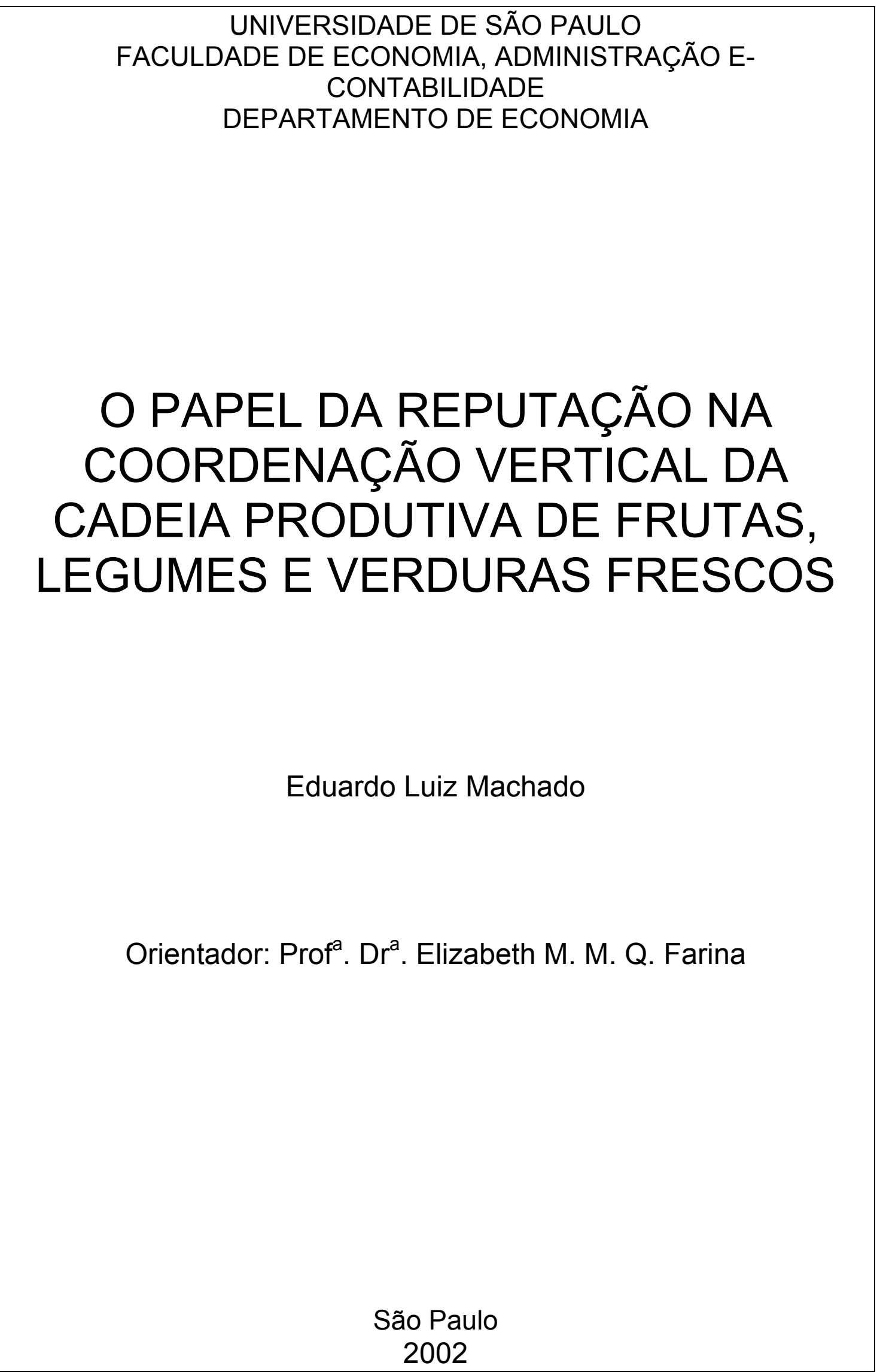


Reitor da Universidade de São Paulo

Prof. Dr. Adolpho José Melfi

Diretor da Faculdade de Economia, Administração e Contabilidade

Prof $^{a}$. Dr ${ }^{a}$. Maria Tereza Leme Fleury

Chefe do Departamento de Economia

Prof $^{\mathrm{a}}$. Dr ${ }^{\mathrm{a}}$. Elizabeth Maria Mercier Querido Farina 


\section{O PAPEL DA REPUTAÇÃO NA COORDENAÇÃO VERTICAL DA CADEIA PRODUTIVA DE FRUTAS, LEGUMES E VERDURAS FRESCOS}

Eduardo Luiz Machado

Orientador: Prof ${ }^{a}$. Dr ${ }^{a}$. Elizabeth M. M. Q. Farina

Tese apresentada junto ao Departamento de Economia da Faculdade de Economia, Administração e Contabilidade da Universidade de São Paulo para obtenção do título de Doutor em Economia. 


\section{FICHA CATALOGRÁFICA}

Machado, Eduardo Luiz

O papel da reputação na coordenação vertical da cadeia produtiva de frutas, legumes e verduras frescos/ Eduardo Luiz Machado - São Paulo: FEA/USP, 2002.

$182 p$.

Tese-Doutorado

Bibliografia

1. Agricultura - Aspectos Econômicos 2. Custo de Transação

3. Produtos Perecíveis.

Faculdade de Economia, Administração e Contabilidade da USP

CDD-338.1 
Put it before them briefly so they will read it, clearly so they will appreciate it, picturesquely so they will remember it and, above all, accurately so they will be guided by its light

Joseph Pulitzer

Aos meus queridos pais (in memoriam) e à minha esposa Flávia 


\section{AGRADECIMENTOS}

Durante a realização deste trabalho tive contato com diversas pessoas que sempre me acolheram e ajudaram nos momentos mais difíceis do programa. Agradeço a todos!

A Prof ${ }^{a}$. Elizabeth Farina pela paciência, dedicação e confiança. A realização desta tese seria uma tarefa impossível sem seus comentários precisos e objetivos.

Aos professores Decio Zylbersztajn e Paulo Picchetti, agradeço os comentários e sugestões durante o exame de qualificação.

Aos colegas de doutorado Luis Eduardo Afonso e Mário Antônio Margarido agradeço a companhia e a paciência nos momentos de desânimo.

Aos meus familiares Ida, Albertina, Gérson, Sizue e Regina que sempre me apoiaram nesta difícil jornada.

Aos amigos da FEA-USP, Fábio, Pedro, Flávia e Roger, e aos excolegas da Escola Politécnica por criarem momentos de descontração e amizade.

Aos professores Peter Zuurbier e Onno Omta pela orientação e atenção prestada durante o período de bolsa sanduíche na Universidade de Wageningen (Holanda).

A minha querida esposa Flávia pela ajuda, companhia e apoio durante os momentos difíceis que vivi durante todo o período.

Por último, ao CNPq, FEA/USP e FIPE pelo auxílio financeiro durante a realização da tese. 


\section{RESUMO}

O objetivo da presente tese consiste na determinação de novas estruturas de governança capazes de fornecer os incentivos e controles necessários para a sustentação de estratégias de diferenciação de produto na cadeia produtiva de frutas, legumes e verduras frescos (FLV), focalizando o papel do varejo moderno na definição e adoção de padrões e classificações privados que visam aumentar a coordenação vertical da cadeia.

A tese mostrará que as novas estratégias adotadas pelo varejo moderno utilizam como mecanismo de coordenação das transações com produtores e consumidores a criação de padrões privados próprios, que têm como objetivo principal informar a qualidade desejada dos produtos comercializados aos produtores e, ao mesmo tempo, atender às exigências de qualidade do consumidor. Novas estruturas de governança surgem buscando sustentar tais transações. A conjunção de mecanismos de sinalização, credibilidade e o efeito reputação constituem o fator chave para a efetividade do padrão privado como mecanismo de coordenação ao longo da cadeia. 


\begin{abstract}
The thesis' objective consists in the determination of new governance structures capable of providing the necessary incentives and controls to the maintenance of product's differentiation strategies in the fresh fruits and vegetables (FFV) productive chain, focusing the role of the modern retailers in the definition and adoption of private standards and classifications that intend to increase the chain's vertical coordination.

The thesis will show that the new strategies adopted by the modern retailers use the creation of private standards as a coordination mechanism of the transactions with producers and consumers, under the main objective of providing information to the producers about the commercialized products' desirable quality and, simultaneously, fill up the consumer's quality demands. New governance structures arise in the search of sustain to these transactions. The conjunction of signalizing mechanisms, credibility and reputation effect is the key factor to the effectiveness of the private standards as a coordination mechanism along the chain.
\end{abstract}




\section{ÍNDICE}

1 INTRODUÇÃO

1

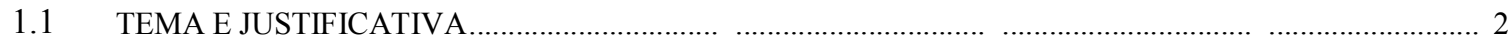

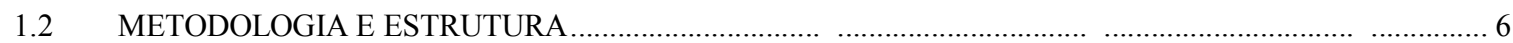

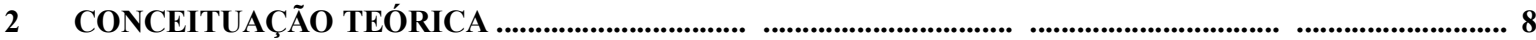

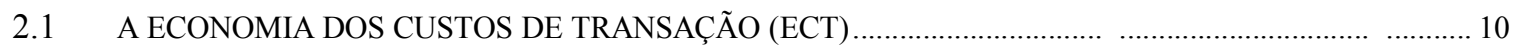

2.1.1 PRESSUPOSTOS COMPORTAMENTAIS DOS AGENTES …................................................ 12

2.1.1.1 OPORTUNISMO E INFORMAÇÃO ASSIMÉTRICA …....................................................... 14

2.1.1.1.1 O OPORTUNISMO PRÉ-CONTRATUAL: SELEÇÃO ADVERSA ................................ 15

2.1.1.1.2 O OPORTUNISMO PÓS-CONTRATUAL: RISCO MORAL E INFORMAÇÃO OCULTA16

2.1.1.2 RACIONALIDADE LIMITADA E INCOMPLETUDE CONTRATUAL ...................................... 19

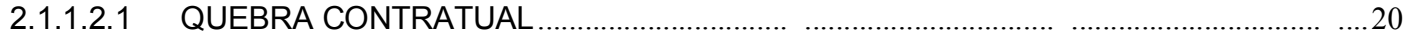

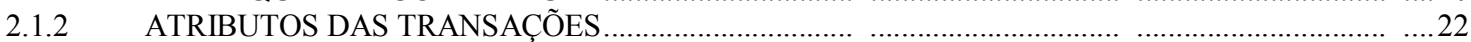

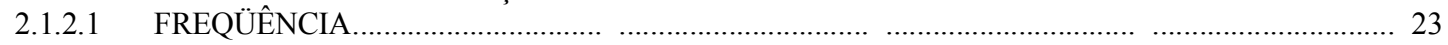

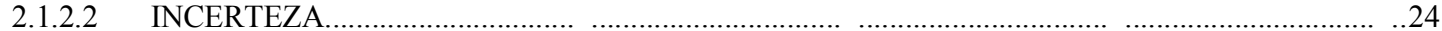

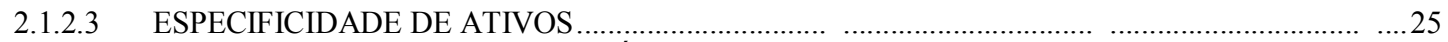

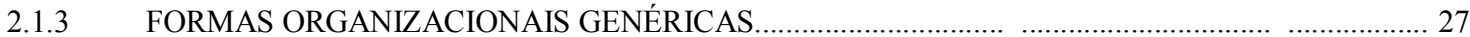

2.1.3.1 ANÁLISE ESTRUTURAL DISCRETA

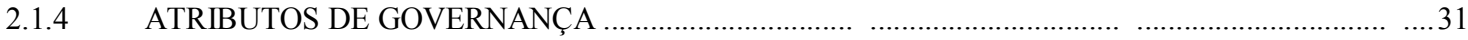

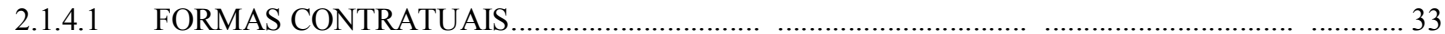

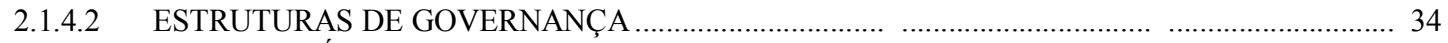

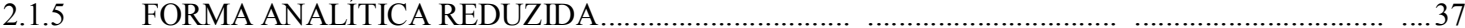

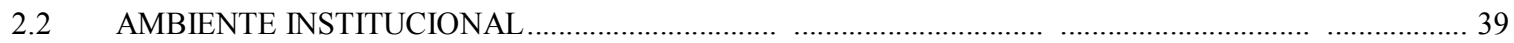

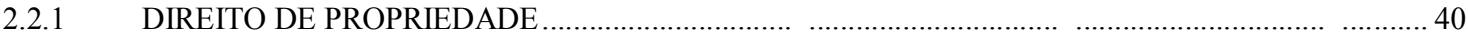

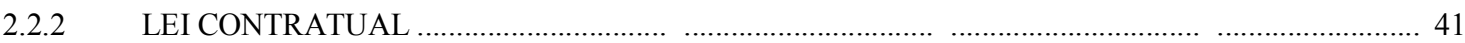

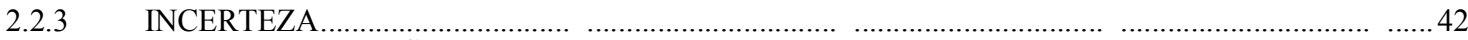

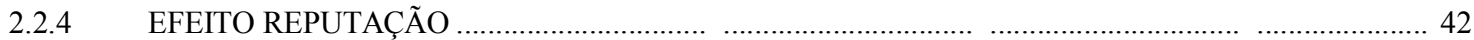

2.2.4.1 RELAÇÃO ENTRE REPUTAÇÃO E FORMAS GENÉRICAS ……......................................... 43

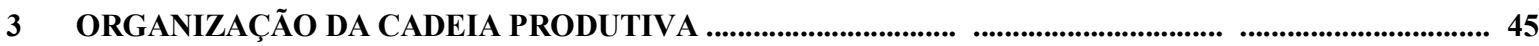

3.1 COORDENAÇÃO DE SISTEMAS AGROINDUSTRIAIS …….......................................................... 47

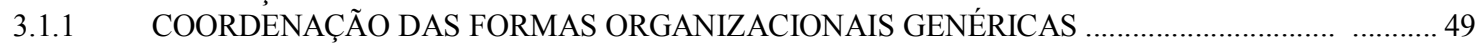

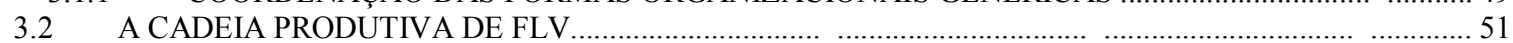

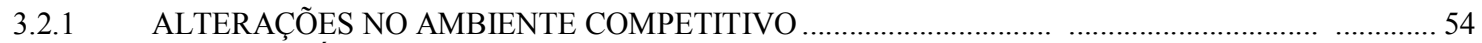

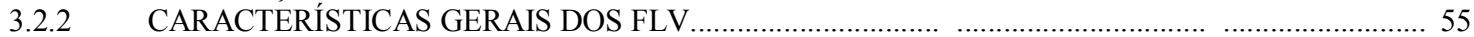

3.2.3 DESCRIÇÃO DAS TRANSAÇÕES ENVOLVENDO FLV …….................................................... .57

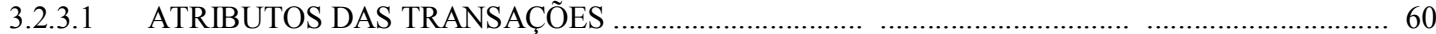

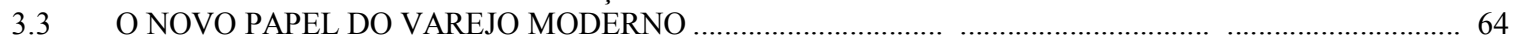

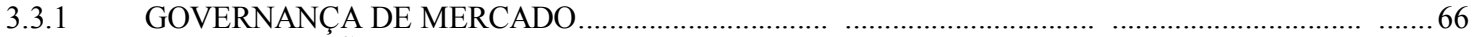

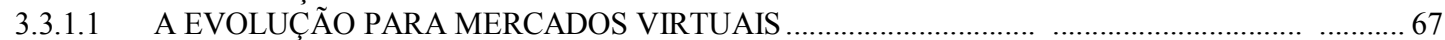

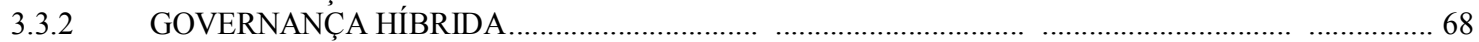

3.3.3 COMPLEMENTARIDADE DAS FORMAS ORGANIZACIONAIS ….......................................... 70

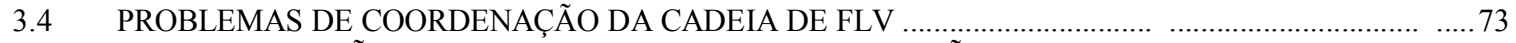

3.5 A PADRONIZAÇÃO COMO MECANISMO DE COORDENAÇÃO .................................................... 75

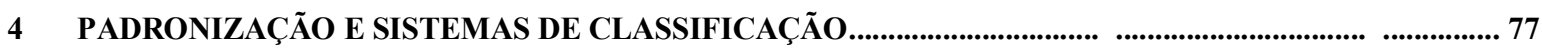

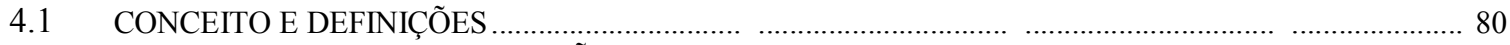

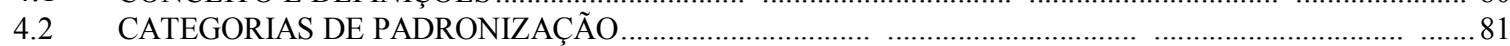

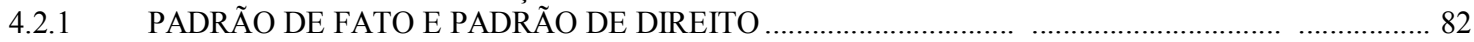

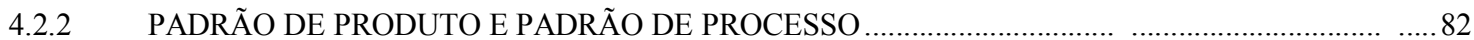

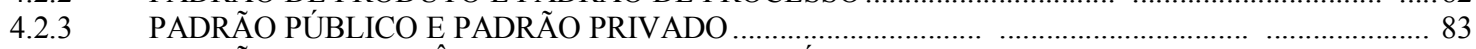

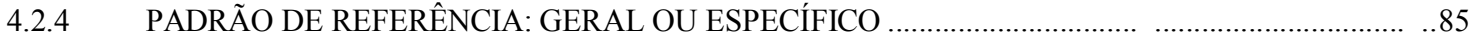

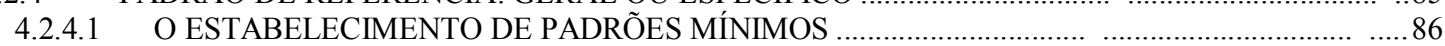

4.3 ASPECTOS GERAIS DA PADRONIZAÇÃO NA CADEIA DE FLV …............................................... 87

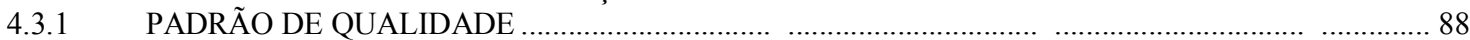

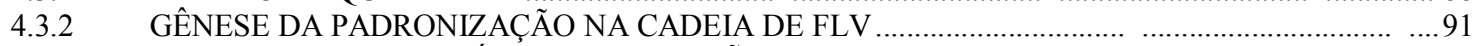

4.3.2.1 O SURGIMENTO EXÓGENO DO PADRÃO …................................................................. 92

4.3.2.2 O SURGIMENTO ENDÓGENO DO PADRÃO 


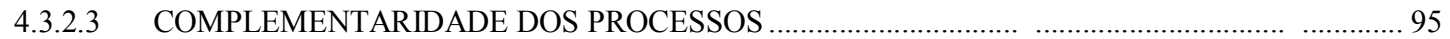

4.3.3 IMPACTOS DISTRIBUTIVOS DA ADOÇÃO DE PADRÕES ……........................................... 96

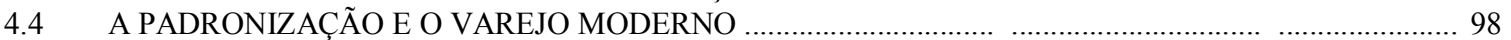

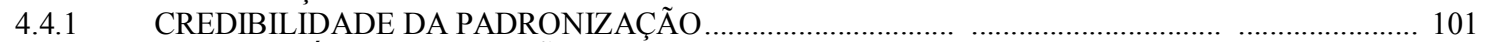

4.4.1.1 ESTRATÉGIA DE CRIAÇÃO DE MARCA COMERCIAL …............................................... 102

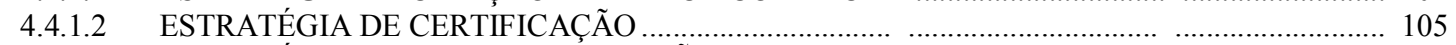

4.4.1.3 ESTRATÉGIA BASEADA EM RELAÇÕES DE LONGO PRAZO ............................................. 108

4.4.1.4 A ADOÇÃO DE UM MIX DE ESTRATÉGIAS...................................................................... 109

4.4.2 SINALIZAÇÃO DA PADRONIZAÇÃO................................................................................... 111

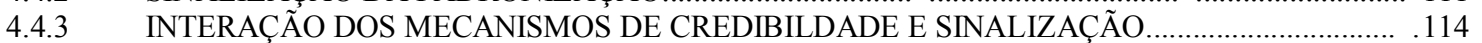

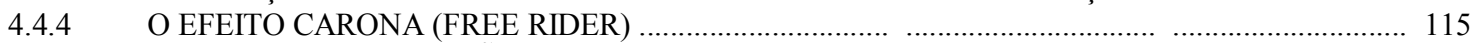

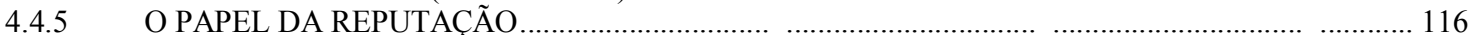

4.4.6 VISÃO GERAL DO PROCESSO DE MUDANÇA INSTITUCIONAL ................................................ 119

5 AS CADEIAS PRODUTIVAS DE FLV HOLANDESA E BRASILEIRA................................................ 122

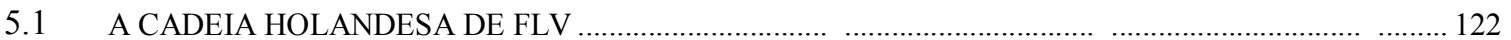

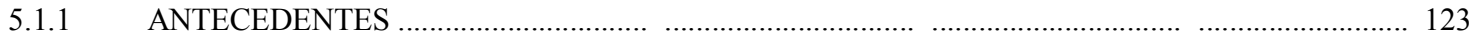

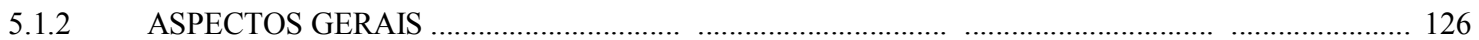

ORGANIZAÇÃO DA CADEIA DE FLV ............................................................................. 129

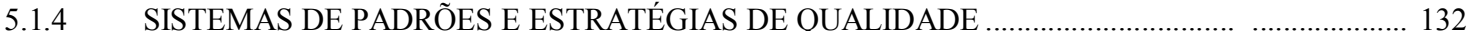

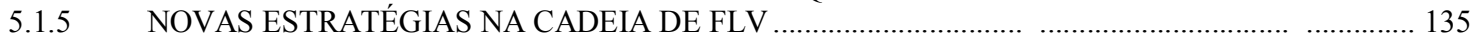

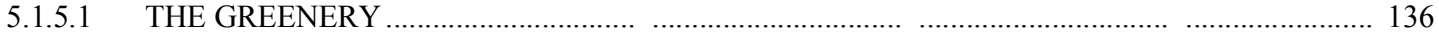

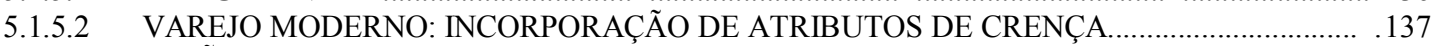

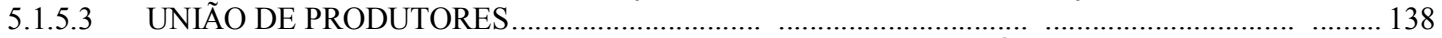

5.1.5.4 VAREJO MODERNO: DESENVOLVIMENTO DE MARCAS PRÓPRIAS..................................138

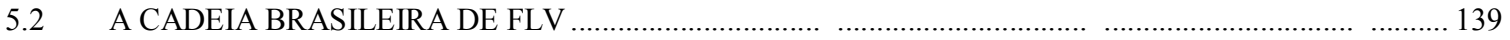

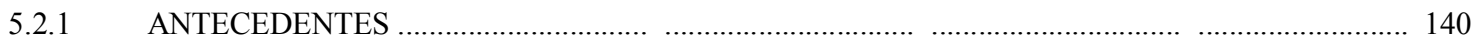

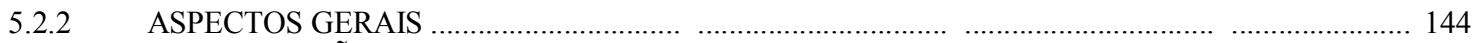

5.2.3 ORGANIZAÇÃO DO MERCADO BRASILEIRO DE FLV ...................................................... 147

5.2.4 SISTEMAS DE PADRÕES E ESTRATÉGIAS DE QUALIDADE ............................................... 151

5.2.5 NOVAS ESTRATÉGIAS DE COORDENAÇÃO ................................................................... 153

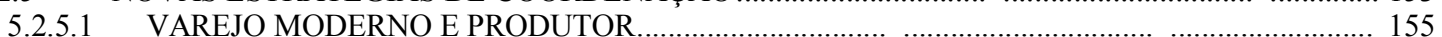

5.2.5.2 VAREJO MODERNO E ATACADISTA …........................................................................ 156

5.2.5.3 INDÚSTRIA DE PROCESSAMENTO E PRODUTORES $\ldots$

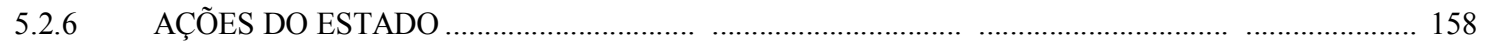

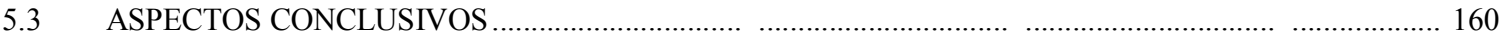

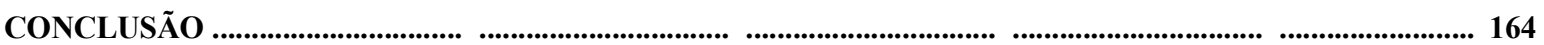

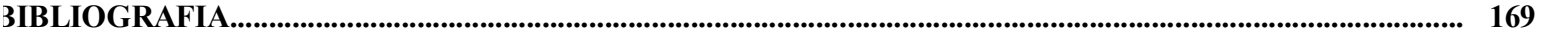




\section{LISTA DE FIGURAS}

Figura 1: Esquema de Três Níveis 009

Figura 2: Estrutura Analítica da ECT 028

Figura 3: Cadeia Produtiva de FLV 052

Figura 4: Descrição das Transações 057

Figura 5: Formação da Reputação 118

Figura 6: Estrutura da Cadeia Holandesa de FLV 129 


\section{LISTA DE QUADROS}

Quadro 1: Distinção das Formas de Governança 032

Quadro 2: Estruturas de Governança e Contratos 035

Quadro 3: Atributos das Transações 061

Quadro 4: Comparação entre Certificado e Marca 107 


\section{LISTA DE TABELAS}

Tabela 1: Composição das Exportações (\%) 127

Tabela 2: Participação de Mercado 131

Tabela 3: Despesa com FLV na Despesa Familiar (\%) 145

Tabela 4: Despesa com Alimentação Fora do Domicílio 146

Tabela 5: Variação do Local de Aquisição de FLV 148

Tabela 6: Setor Supermercadista $\quad 150$

Tabela 7: Participação do Setor (2000) 150 


\section{LISTA DE GRÁFICOS}

Gráfico 1: Custo de Governança e Especificidade de Ativos

038

Gráfico 2: Distribuição Geográfica do Consumo de FLV (\%)

Gráfico 3: Índice de Preços ao Consumidor Deflacionado 


\section{INTRODUÇÃO}

O objetivo da presente tese consiste na identificação de novas estruturas de governança capazes de fornecer os incentivos e controles necessários para a sustentação de estratégias de diferenciação de produto na cadeia produtiva de frutas, legumes e verduras frescos (FLV), focalizando o papel do varejo moderno ${ }^{1}$ na definição e adoção de padrões e classificações privados que visam aumentar a coordenação vertical da cadeia.

A importância de sistemas de classificação e padronização na organização dos mercados agroalimentares aumentou significativamente em decorrência da redução das barreiras comerciais e do aumento da preocupação com questões associadas à qualidade dos alimentos. Uma importante tendência observada indica uma crescente elevação da participação de sistemas privados de classificação e padronização em substituição aos antigos sistemas públicos. A falta do padrão público efetivo incentiva firmas e associações a criarem e impingirem padrões privados para comunicar qualidade, segurança e diferenciação do produto aos demais agentes da cadeia. A tese analisa a estratégia adotada pelo varejo moderno para superar o problema enfrentado pelo sistema público na definição e adoção de padrões de qualidade.

A tese foi inspirada pelo recente desenvolvimento da cadeia produtiva brasileira de FLV, onde, ao mesmo tempo em que surgem padrões privados para sustentar estratégias de diferenciação, existem padrões públicos que não conseguem garantir a segurança dos alimentos e o funcionamento eficiente do mercado. A existência de fortes grupos de interesse no interior da cadeia dificulta a implementação de novos padrões para os produtos. O processo de mudança institucional envolve a criação de novas estruturas de governança capazes de fornecer o suporte necessário às ações geradoras e controladoras dos novos padrões, visando melhorar a coordenação vertical ao longo da cadeia de FLV.

\footnotetext{
${ }^{1} \mathrm{O}$ varejo moderno inclui supermercados, hipermercados e lojas de desconto.
} 


\subsection{TEMA E JUSTIFICATIVA}

Nas sociedades modernas, a oferta de alimentos envolve várias organizações, todas fortemente conectadas dentro de uma cadeia lógica de funcionamento, que podem ser vistas como um conjunto de relações verticais estabelecidas por contratos formais ou informais, representativos de uma estrutura de governança própria.

O sistema de abastecimento mundial de alimentos encontra-se em fase de transformação decorrente da rápida internacionalização dos mercados, do desenvolvimento de novas tecnologias de informação e da otimização da logística de transporte. A estratégia de diferenciação pela qualidade e a incorporação de valor adicionado aos produtos alimentares tornaram-se uma tendência mundial.

O processo caracteriza-se por alterações significativas na base produtiva, que vêm aumentando a interdependência entre os segmentos produtivos e elevando a competitividade do setor. $O$ aprofundamento da interdependência entre os diversos setores produtivos torna a dinâmica individual de cada agente um fator de forte influência direta sobre todos os outros agentes da cadeia produtiva (Dosi, 1984:284).

Ao mesmo tempo, o rápido avanço da biotecnologia agrícola tem gerado uma crescente demanda pela obtenção e distribuição de informação a respeito da segurança dos alimentos e das características qualitativas dos produtos no interior das cadeias produtivas. A existência de características não detectáveis facilmente pelos agentes (atributos de crença), mesmo após o consumo do bem, afeta negativamente a capacidade de comercialização dos produtos. A criação de instrumentos capazes de fornecer informação crível a respeito dos atributos de crença com baixo custo torna-se parte essencial das novas estratégias dos agentes.

Em particular, tais modificações vêm gerando um rápido processo de transformação organizacional e estrutural ao longo da cadeia produtiva de FLV. O caminho percorrido pelo produto da fazenda ao consumidor tornou-se diferente, 
diminuindo a importância dos terminais atacadistas e aumentando o número de transações diretas entre produtores e varejistas.

Existe a percepção de que as relações entre os agentes ao longo da cadeia de FLV vêm se modificando rapidamente na tentativa de acompanhar as mudanças estruturais, afetando o lucro, a qualidade dos produtos e o bem-estar dos consumidores. Trata-se de um processo dinâmico que envolve redistribuição da renda entre os agentes da cadeia. Assim, é natural a expectativa ligada ao surgimento de grupos contrários às mudanças no sistema atual, tornando o processo de reestruturação uma questão também dependente de pressões políticas.

A rápida modificação da distribuição do poder de mercado entre os agentes da cadeia exige que eles possuam dinamismo suficiente para se adaptar com agilidade às transformações do ambiente institucional. A constante busca por novas formas de organização é um fator de sobrevivência em uma estrutura de mercado competitiva em transformação.

Simultaneamente, novos hábitos comportamentais dos consumidores vêm aumentando a importância do varejo moderno nas vendas de FLV. Segundo McLaughin e Perosio (1994), a importância do departamento de FLV aumentou significativamente no interior da cadeia varejista moderna. A estratégia adotada associa a credibilidade da loja junto aos consumidores por vender produtos de boa qualidade aos atributos dos produtos frescos que oferece, cujas características qualitativas não são facilmente perceptíveis (Lima Filho, 1999).

Em trabalho empírico realizado para o mercado de pêssegos frescos nos EUA, Bagnara (1996) constatou que as características dos produtos interagem com as características da loja, afetando diretamente a percepção da qualidade pelo consumidor. Assim, ao ser mais exigente que o setor varejista tradicional em termos de qualidade, grau de maturidade, data de entrega e embalagem dos produtos, o varejo moderno transmite credibilidade a respeito da qualidade dos produtos frescos oferecidos ao consumidor em suas lojas, conquistando os clientes insatisfeitos com produtos vendidos em outros equipamentos varejistas, e provocando um progressivo aumento de sua participação na comercialização de 
FLV. Entretanto, o varejo moderno tem enfrentado enormes dificuldades para conseguir o suprimento regular e de alta qualidade de produtos frescos.

O mercado de FLV é um dos menos desenvolvidos no Brasil, sendo o crescimento limitado pela dificuldade, tanto do setor público quanto do setor privado, de estabelecer padrões mínimos sobre as características dos produtos comercializados e pela falta de políticas que incentivem o desenvolvimento de tais padrões. Recentemente, foram feitas algumas tentativas infrutíferas para a definição e disseminação de padrões públicos na cadeia brasileira de FLV (Sousa et al., 2000). Paralelamente, após o início do processo de estabilização econômica em 1994 ocorreu o ingresso de um grande número de cadeias varejistas internacionais no país, criando um novo padrão de competição entre os equipamentos varejistas ${ }^{2}$.

Como se encontram mais próximos do consumidor final, o varejo moderno e empresas processadoras de alimentos estão mais aptos a captar movimentos relativos às mudanças sócio-econômicas e de estilo de vida da população. Por outro lado, estão mais sujeitos a prejuízos decorrentes da incerteza com relação à quantidade e qualidade dos produtos comercializados em virtude da falta de padronização.

A dificuldade de crescimento do setor está diretamente associada à inexistência de padrões efetivos para os FLV. A falta de padronização não permite a coordenação eficiente dos agentes ao longo da cadeia produtiva, impedindo que os ganhos potenciais de eficiência ocorram, atrapalhando o crescimento do varejo moderno. A falta do padrão público efetivo tem incentivado firmas e associações a criarem e impingirem padrões privados para comunicar a qualidade, a segurança e a diferenciação do produto aos demais agentes da cadeia.

O surgimento de diferentes estruturas de governança entre os agentes da cadeia de FLV deve-se à busca de adequação às novas condições competitivas do setor. Entretanto, nenhuma forma implementada até o momento tornou-se predominante. A observação do setor de FLV mostra que tem sido difícil definir

\footnotetext{
${ }^{2}$ Locais especializados na distribuição de alimentos, como quitandas, sacolões, centrais de abastecimento, feiras livres, entre outros.
} 
qual estrutura organizacional é necessária à sustentação e promoção da padronização, pública ou privada (Farina e Machado, 2000).

Um sistema de coordenação eficiente deve possuir a capacidade de transmitir informações, estímulos e controles ao longo de toda cadeia produtiva (Farina et al., 1997:146). A implementação de padrões e sistemas de classificação tem a capacidade de afetar positivamente a coordenação vertical da cadeia produtiva de FLV ao melhorar o fluxo de informações entre os agentes em razão da homogeneização da linguagem e facilitar possíveis estratégias de segmentação.

Em relação ao varejo moderno duas questões fundamentais consistem em determinar qual tipo de informação o padrão privado deve transmitir para os agentes ao longo da cadeia produtiva e como provê-los de tal informação. À montante, o varejo moderno deve ter a capacidade de fornecer incentivos adequados para garantir o recebimento dos produtos em conformidade com o padrão exigido e, ao mesmo tempo, possuir instrumentos de controle eficazes para coibir a não conformidade. À jusante, o varejo moderno precisa transmitir a informação que a conformidade com os padrões exigidos foi atingida.

A credibilidade do padrão privado consiste em um fator importante para sua efetividade. O surgimento indiscriminado de padrões privados, criados por diferentes agentes no interior da cadeia produtiva, afeta adversamente a coordenação vertical ao gerar um volume excessivo de informações diferentes e, às vezes conflitantes entre si, a respeito do mesmo produto, impedindo que o consumidor consiga identificar adequadamente a característica desejada, reduzindo sua efetividade.

No longo prazo, o conjunto de informação escolhido e a maneira de comunicação constituem a forma de sinalização empregada pelo varejo moderno. A escolha da estratégia de sinalização mais adequada torna-se essencial para a resolução do problema.

O presente estudo mostrará que as novas estratégias adotadas pelo varejo moderno utilizam como mecanismo de coordenação das transações com produtores e consumidores a criação de padrões privados próprios, que têm como 
objetivo principal informar a qualidade desejada dos produtos comercializados aos produtores e, ao mesmo tempo, atender às exigências de qualidade do consumidor. Novas estruturas de governança surgem buscando sustentar tais transações. A credibilidade do varejista moderno, obtida pelo efeito reputação, é um fator chave para a efetividade do padrão privado como mecanismo de coordenação ao longo da cadeia.

\subsection{METODOLOGIA E ESTRUTURA}

A metodologia empregada para a análise das transações e estruturas de governança ao longo da cadeia produtiva de FLV baseia-se na literatura sobre Economia dos Custos de Transação (ECT) e em informações obtidas em entrevistas com varejistas, atacadistas, produtores e órgãos governamentais do setor no Brasil e na Holanda.

A escolha do Brasil e da Holanda para a realização do estudo comparativo deve-se ao fato das cadeias produtivas de FLV dos dois países estarem em estágios diferentes de desenvolvimento dos mecanismos de coordenação das transações. A análise estática das transações fornece uma avaliação do ambiente institucional atual de cada país, permitindo a projeção da dinâmica futura da cadeia brasileira de FLV. Assim, a partir da análise contratual estática de dois estágios diferentes de desenvolvimento de uma mesma cadeia produtiva é possível avaliar o processo de mudança do ambiente institucional necessário para a cadeia menos coordenada atingir um estágio mais elevado de coordenação. A análise permite apenas localizar fraquezas e virtudes da cadeia produtiva menos coordenada, não sendo um indicativo preciso da configuração do ambiente institucional no futuro.

Os dados empíricos utilizados foram obtidos em entrevistas com supermercados, atacadistas, produtores e órgãos governamentais. Uma base de dados complementar utilizará a Pesquisa de Orçamento Familiar (POF-IBGE), informações operacionais da Companhia de Entrepostos e Armazéns Gerais do 
Estado de São Paulo (CEAGESP), preços agrícolas coletado pela FIPE e Statistics Netherlands (CBS).

Com o intuito de alcançar o objetivo proposto, a tese foi dividida em quatro capítulos adicionais. No capítulo 2 são apresentados conceitos da Nova Economia Institucional (NEI), particularmente da Economia dos Custos de Transação (ECT), que servirão de base teórica para a análise das relações entre os agentes da cadeia de FLV. A estrutura analítica da ECT permite analisar como os agentes econômicos escolhem os mecanismos de coordenação que conduzirão as transações (Williamson, 1985, 1996). A diversidade de modos organizacionais é explicada como uma resposta dos agentes econômicos aos atributos diferenciados das transações.

No capítulo 3 caracteriza-se a cadeia produtiva de FLV, descrevendo a complexidade dos produtos e os principais atributos de suas transações. A partir do referencial teórico da ECT são discutidas estratégias contratuais para o suprimento e fornecimento dos produtos frescos pelo varejo moderno.

Inicialmente, discute-se no capítulo 4 questões relacionadas à padronização (conceito, funções e tipos). Em seguida, descreve-se duas formas de gênese do padrão, endógena ou exógena à cadeia produtiva. Discute-se a adoção de padrões mínimos e a utilização de mecanismos de credibilidade ao padrão adotado. Por último, descreve-se o papel do varejo moderno no processo de implementação de padrões na cadeia produtiva de FLV.

No último capítulo, é efetuado um estudo empírico comparativo entre Brasil e Holanda. A cadeia produtiva holandesa de FLV encontra-se em uma fase mais desenvolvida que a brasileira, apresentando sistemas de classificação e padrões para os produtos e ótima estrutura de distribuição. A comparação permite localizar problemas potenciais do processo de modernização do sistema de distribuição brasileiro e propostas de possíveis medidas corretivas.

Por fim, colocam-se algumas questões para reflexão sobre o futuro da cadeia brasileira de FLV. O objetivo é incentivar novas pesquisas sobre o assunto e, ao mesmo tempo, identificar possíveis ações de curto e longo prazo que auxiliem o desenvolvimento do setor. 


\section{CONCEITUAÇÃO TEÓRICA}

Joskow (1995) entende a Nova Economia Institucional (NEI) como uma linha de pensamento econômico que parte do paradigma clássico da Organização Industrial Moderna e expande o conhecimento em direção ao estudo do ambiente institucional $^{3}$ e das variáveis transacionais que caracterizam a organização das firmas e dos mercados. O corpo teórico atual foi construído a partir dos trabalhos pioneiros desenvolvidos por Commons (1924, 1934), Coase (1937), Knight (1941), Barnard (1938), Hayek (1945), Simon (1978), e, recentemente, por North (1986) e Williamson $(1985,1996)$.

A NEI apresenta duas linhas principais de pesquisa que são complementares entre si. A primeira linha está centralizada na análise de macroinstituições, sendo mais conhecida como a abordagem do Ambiente Institucional, onde os trabalhos de Coase (1957), Davis e North (1971) e North $(1986,1991)$ são os mais representativos. O foco central de análise é o efeito de diferentes instituições sobre o desempenho econômico e o surgimento das instituições.

A segunda linha tem enfoque centrado nas microinstituições, sendo mais conhecida como a abordagem das Estruturas de Governança ou Teoria dos Contratos, sendo os trabalhos de Coase (1937) e Williamson (1993) importantes referências da linha de pesquisa. $O$ ambiente institucional agora é tratado como uma variável exógena, permanecendo constante nas análises comparativas. 0 foco central consiste em identificar como diferentes estruturas de governança ${ }^{4}$ alinham-se aos atributos da transação.

Procurando relacionar as duas abordagens, Williamson (1993) propôs um esquema de três níveis (Figura 1) onde o ambiente institucional, a estrutura de governança e os indivíduos interagem entre si, influenciando-se mutuamente. Resumidamente, o esquema apresentado por Williamson mostra que a estrutura

\footnotetext{
${ }^{3} \mathrm{O}$ ambiente institucional é o conjunto de regras políticas, econômicas, sociais e legais que constituem a base para a produção, troca e distribuição (Davis e North, 1971:6).

${ }^{4}$ Williamson (1985:378) define estrutura de governança como a matriz institucional na qual a integridade de uma transação é decidida.
} 
de governança desenvolve-se dentro dos limites criados pelo ambiente institucional e pelos pressupostos sobre o comportamento dos indivíduos. As regras do ambiente institucional determinam as formas organizacionais que prevalecerão na estrutura de governança (a). Paralelamente, as estratégias organizacionais podem também modificar o ambiente institucional (b). Os pressupostos comportamentais do indivíduo, que se supõe ter racionalidade limitada e oportunismo, são condições necessárias para o surgimento de custos de transação na economia (c). Por último, tanto o ambiente institucional quanto as estruturas de governança afetam os indivíduos (d).

FIGURA 1: ESQUEMA DE TRÊS NÍVEIS

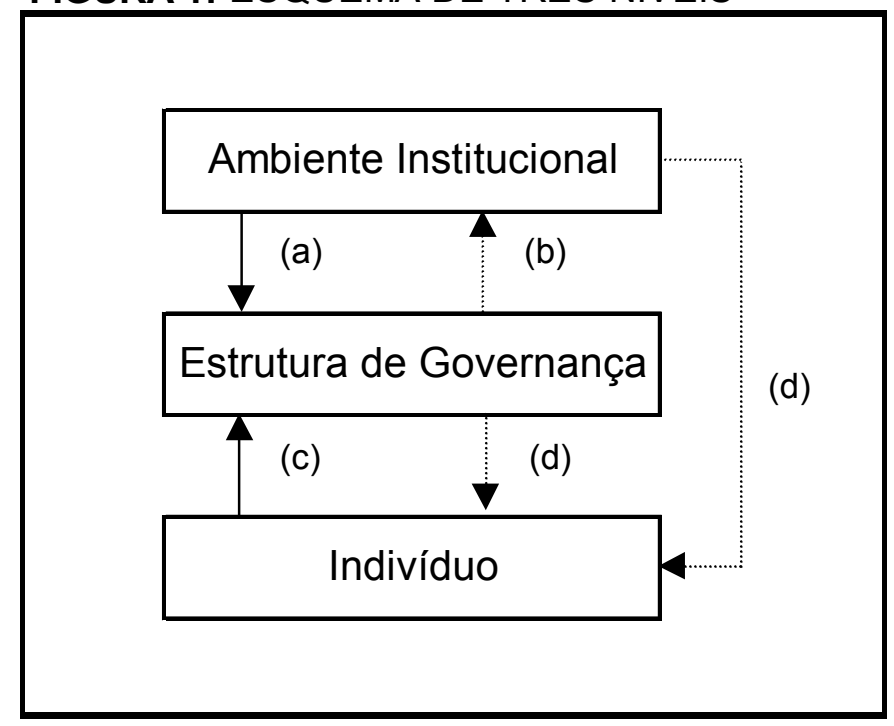

Fonte: Williamson (1993)

Assim, as abordagens de Estruturas de Governança e do Ambiente Institucional quando associadas à teoria da Organização Industrial Moderna fornecem um instrumental analítico que permite um entendimento mais amplo e completo da organização do mercado e seu desempenho.

Inserida na linha de pesquisa das Estruturas de Governança encontra-se a Economia dos Custos de Transação (ECT), que utiliza um enfoque microanalítico para compreender as instituições e considera o ambiente institucional no qual as transações estão inseridas como dadas no momento de análise. Assim, a partir da 
análise contratual estática de estágios diferentes de desenvolvimento de uma mesma cadeia produtiva em diferentes países é possível avaliar indiretamente o processo de mudança do ambiente institucional. A estrutura analítica contratual da ECT é a mais adequada para explicar a organização de sistemas produtivos e, assim, alcançar os objetivos propostos pela tese.

\subsection{A ECONOMIA DOS CUSTOS DE TRANSAÇÃO (ECT)}

O termo custo de transação foi conceitualmente introduzido na literatura econômica em Coase (1937) como simplesmente o custo de utilizar o mecanismo de preços. A definição de Coase teve diversas contribuições ao longo do tempo. Tal fato dificultou a adoção de uma terminologia padrão na literatura sobre custos de transação, permitindo a coexistência de uma variedade de conceitos para o termo.

Arrow (1969:28) interpreta custo de transação como o custo de movimentar sucessivamente o sistema econômico. Tais custos são distintos dos custos de produção, constituindo o equivalente econômico ao conceito de atrito na física. Furubotn e Richter (1991:3) genericamente definem custo de transação como o custo necessário para o mecanismo econômico e social funcionar, não estando diretamente associados à produção, mas surgiriam à medida que os agentes relacionam-se e problemas coordenativos de suas ações apareçam. Barzel (1989:4) entende o custo de transação como o custo associado à transferência, captação e proteção de direitos. Segundo Eggertsson (1990), em termos gerais, os custos de transação surgem quando os indivíduos trocam direitos de propriedade entre si. Williamson (1985) ampliou o conceito inicial de Arrow, definindo custos de transação como os custos comparativos de planejar, adaptar e monitorar estruturas de governança alternativas. Por fim, segundo Cheung (1990) o custo de transação refere-se aos custos de elaboração e negociação de contratos; mensuração e fiscalização de direitos de propriedade; monitoramento e desempenho; e organização de atividades. Apesar de abrangente, a definição de Cheung desconsidera o custo da ineficiência adaptativa frente às mudanças do 
ambiente econômico, que é considerado um dos problemas econômicos fundamentais por Hayek (1945:523) e Barnard (1938).

A compreensão dos custos de transação no sentido de Cheung ocorre comumente de forma implícita na literatura. A ampla definição de Cheung (1990) permite abordar diversos aspectos referentes à coordenação vertical das cadeias produtivas sob o enfoque da ECT, sendo a mais adequada para análise de situações que envolvam transações complexas. Assim, a tese utilizará o conceito de custo de transação de Cheung para a análise das transações da cadeia produtiva de FLV.

A abordagem predominante na Teoria Econômica assume que todas as partes envolvidas em um processo de troca possuem a quantidade de informação necessária para capacitá-las a efetuar uma escolha racional. Tal fato implica em uma situação com custo de transação igual a zero. Entretanto, em determinadas contingências a informação encontra-se assimetricamente distribuída entre as partes envolvidas na troca. Neste caso, os custos de transação não podem ser negligenciados, devendo suas implicações ser devidamente avaliadas.

A ECT adota uma perspectiva com orientação contratual e preconiza que qualquer situação que possa ser formulada como um problema contratual pode ser investigado, com vantagem, em termos de economia de custos de transação. A unidade básica de análise é a transação, que permite a utilização de um enfoque mais microanalítico para o entendimento das organizações econômicas.

A teoria identifica dois tipos de custos de transação que são interdependentes e determinados simultaneamente. $O$ custo de transação ex-ante é o custo de planejamento, negociação e adoção de salvaguardas de um acordo, enquanto o custo de transação ex-post assume a forma de custos originários de desvios dos alinhamentos propostos para a transação no contrato; custos de barganha incorridos se esforços bilaterais são efetuados para corrigir os desalinhamentos; custos de organização e movimentação associados à estrutura de governança aos quais as disputas são submetidas.

A ECT analisa o modo como os agentes econômicos escolhem os mecanismos de coordenação que conduzirão as transações (Williamson, 1985, 
1996). A diversidade de modos organizacionais é explicada como uma resposta dos agentes econômicos à variedade de problemas de coordenação das transações. As características das transações fornecem os custos transacionais que determinam a forma de governança existente.

A abordagem permite determinar quais estruturas de governança emergirão do ambiente institucional, sujeito a leis contratuais, pressupostos comportamentais e atributos das transações, baseado num critério minimizador de custos de transação.

\subsubsection{PRESSUPOSTOS COMPORTAMENTAIS DOS AGENTES}

A ECT assume que os indivíduos estão sujeitos à racionalidade limitada e são inclinados ao oportunismo, que constitui uma condição de procura do autointeresse com avidez (Williamson, 1996:cap. 9).

Williamson (1985) classifica a racionalidade dos agentes em forte, fraca e limitada. O primeiro conceito supõe que os indivíduos utilizam todo o conjunto de informação disponível, conseguindo maximizar seu objetivo. O papel da instituição é suprimido em favor da visão da firma como uma função de produção e os consumidores como funções utilidades.

O segundo conceito, a racionalidade fraca ou orgânica "assume que a capacidade racional dos indivíduos não é suficiente para direcionar a escolha de um quadro institucional com a finalidade de amenizar problemas contratuais expost" (Azevedo, 1996:42).

A última forma, o conceito de racionalidade limitada foi proposto inicialmente por Simon $(1957,1961)$, que reconheceu a impossibilidade de previsão de todas as possíveis contingências de uma transação, rompendo com a visão tradicional utilizada em Economia de racionalidade ilimitada.

$\mathrm{Na}$ racionalidade limitada, assume-se que os agentes econômicos são "intendedly rational, but only limitedly so" (Simon, 1961:24). O recurso "racionalidade" seria escasso, tornando sua utilização custosa aos indivíduos. Uma conseqüência do pressuposto consiste na idéia de que os contratos são 
invariavelmente incompletos, criando a necessidade de adaptações e negociações ex-post para reduzir a própria incompletude. Simplificadamente, o contrato será completo caso todas as possíveis contingências futuras sejam reconhecidas antecipadamente, ou incompleto, caso eventuais lacunas surjam ao longo do tempo.

O segundo pressuposto, o oportunismo, refere-se a condição do indivíduo na busca dos próprios interesses. Enquanto na ortodoxia adota-se que os indivíduos são egoístas, mas cumprem os termos contratuais durante a execução do contrato (auto-interesse simples), na ECT não há restrições ao comportamento egoísta dos indivíduos, que podem agir sem etica antes ou depois da efetivação da transação (oportunismo forte ou auto-interesse com avidez). O oportunismo forte refere-se "às formas incompletas e distorcidas de abertura de informações, voltadas para a obtenção de benefícios próprios" (Zylbersztajn, 2000).

A existência do oportunismo pode impor perdas significativas aos agentes, modelando as estruturas de governança de forma a impedir tal comportamento pelas partes envolvidas na transação (Williamson, 1985). Apenas a possibilidade do comportamento oportunista é suficiente para justificar a inclusão de cláusulas de salvaguarda nos contratos.

Utilizando como critério diferenciador o pressuposto comportamental preponderante na transação, Milgrom e Roberts (1992:29) dividem o custo de transação em custos de motivação e custos de coordenação. O primeiro tipo ocorre principalmente em razão do oportunismo dos agentes, referindo-se ao custo de motivar agentes especializados a alinhar seus interesses, como por exemplo, custo de comportamento oportunista (Williamson, 1975, 1985) e custo de agência (Jensen e Meckling, 1976). O segundo tipo refere-se ao custo de coordenar as ações entre os agentes especializados. O custo de coordenação tem como exemplos o custo de obter informação (Stigler, 1961), o custo de coordenação de insumos na produção (Alchian e Demsetz, 1972) e o custo de mensuração (Barzel, 1982), sendo a racionalidade limitada a principal fonte geradora de tal custo de transação. 
Os dois pressupostos comportamentais fornecem a base de apoio para 0 surgimento dos custos de transação e, conseqüentemente, a estrutura de governança apropriada para a realização de uma transação específica.

\subsubsection{OPORTUNISMO E INFORMAÇÃO ASSIMÉTRICA}

A nova linha de pesquisa originada a partir do relaxamento da hipótese de informação perfeita gerou uma série de teorias complementares entre si que receberam o nome genérico de "Teoria dos Contratos" (Azevedo, 1996:15). Entre elas destacam-se: Risco Moral (Arrow, 1968), Seleção Adversa (Akerlof, 1970), Sinalização (Spence, 1973), Agente-Principal (Jensen e Meckling, 1976) e Mechanism Design (Laffont e Masking, 1980). A quebra do pressuposto de informação perfeita nos modelos econômicos trouxe novas perspectivas para a compreensão acerca do modo como surgem certos tipos de falhas de mercado. $O$ emprego da abordagem contratual visa facilitar o entendimento das imperfeições de mercado originadas pela quebra do pressuposto.

Uma das hipóteses fundamentais para garantir a otimalidade de uma economia competitiva consiste na condição de que todos os agentes econômicos detêm o mesmo conjunto de informações acerca de todas as variáveis econômicas, não podendo ocorrer casos onde um ou mais agentes econômicos possuam algum tipo de informação que os outros desconheçam. A hipótese de informação perfeita garante que todas as características de qualquer bem são observadas por todos os participantes do mercado. Entretanto, a informação é freqüentemente distribuída de forma desigual entre os agentes, gerando algum tipo de ineficiência que impede a ocorrência do Equilíbrio Ótimo de Pareto. Por exemplo, imperfeições decorrentes da assimetria informacional sobre a qualidade do bem entre os operadores da cadeia produtiva podem ocasionar a redução dos preços e da lucratividade (Akerlof, 1970).

A partir dos trabalhos de Arrow (1968) e Akerlof (1970), análises envolvendo as implicações da assimetria de informação foram impulsionadas. Grande parte do uso da hipótese sobre informação assimétrica na Teoria 
Econômica é motivada pela tentativa de compreender a ineficiência de um determinado mercado.

O pressuposto relacionado ao oportunismo dos agentes associa-se fortemente com a existência de informação assimétrica entre as partes envolvidas na transação e aos custos de obtenção de informação. Especificamente no caso dos produtos hortícolas e frutas, que apresentam grande diversidade e variabilidade, o problema causado pela assimetria de informação pode adquirir grandes proporções, implicando no surgimento de custos de transação associados às salvaguardas ex-ante e/ou ao monitoramento ex-post. Em geral, os problemas gerados pela assimetria de informação são associados ao comportamento de natureza ética, afetando diretamente as relações entre os agentes. Se os agentes econômicos tivessem uma orientação benigna, não oportunista, os custos de transação não seriam relevantes.

Os principais problemas contratuais decorrentes de assimetria de informação podem ser agrupados em duas categorias, de acordo com o momento de surgimento do comportamento oportunista das partes: pré-contratual ou póscontratual. Especificamente, a literatura utiliza os termos seleção adversa, risco moral, informação oculta para se referir a tais comportamentos.

\subsection{O OPORTUNISMO PRÉ-CONTRATUAL: SELEÇÃO ADVERSA}

Trata-se do comportamento oportunista por uma das partes que ocorre antes da assinatura do contrato. O principal problema decorrente do oportunismo pré-contratual é conhecido na literatura como seleção adversa. Segundo Milgrom e Roberts (1992:595), o termo seleção adversa refere-se ao problema relacionado ao oportunismo pré-contratual que surge quando uma parte possui algum tipo informação privada que afetará negativamente a outra parte na vigência do contrato.

Akerlof (1970) foi o pioneiro na descrição formal da existência do problema de seleção adversa decorrente da assimetria informacional, utilizando como exemplo o mercado de carros usados. Como esclarecido por Akerlof, em 
mercados com diferentes qualidades do mesmo bem, freqüentemente, o vendedor possui mais informação do que o comprador a respeito da qualidade do produto negociado. A inexistência de um mecanismo que permita aos compradores diferenciar a qualidade dos produtos provocará a completa eliminação do mercado das transações envolvendo os produtos de boa qualidade, deixando que somente os produtos de qualidade inferior sejam comercializados. Como desconhece a qualidade exata do produto, o consumidor está disposto a pagar pela qualidade esperada do bem, cujo valor, por definição, é inferior ao valor do bem de alta qualidade. Assim, só é interessante ao vendedor comercializar produtos de qualidade igual ou inferior à qualidade esperada.

Em suma, transações de bens com diferentes qualidades nas quais o vendedor não possui meios para convencer o comprador a respeito da qualidade do produto comercializado tendem a ser ineficientes, na medida em que o fenômeno de seleção adversa elimina as transações dos produtos de boa qualidade, podendo, em situações extremas, causar o colapso do mercado.

Soluções para o problema de seleção adversa em transações com produtos de descrição complexa e qualidade diferenciada envolvem a necessidade dos vendedores utilizarem sinais orientados ao consumidor na tentativa de mostrar os atributos do produto oferecido. Assim, o vendedor, ao prover o comprador de informações confiáveis a respeito do bem, como certificados de qualidade ou garantias, está tentando reduzir a quantidade de informação assimétrica e, conseqüentemente, o custo de transação.

\subsection{O OPORTUNISMO PÓS-CONTRATUAL: RISCO MORAL E INFORMAÇÃO OCULTA}

Mas-Colell, Whinston e Green (1995:477) identificam dois tipos de problemas informacionais pós-contratuais: informação oculta (ou conhecimento oculto) e ação oculta. A distinção foi inicialmente sugerida em Arrow (1985) e Hart e Holmstrom (1987). Na informação oculta, a ação do Agente é observável e verificável pelo Principal, mas uma informação relevante ao resultado final é 
adquirida e mantida somente pelo Agente; enquanto que, na ação oculta, a ação do Agente não é observável ou verificável pelo Principal ${ }^{5}$.

Segundo Azevedo (1996:15) uma ação torna-se observável quando o Principal consegue avaliá-la em quantidade e/ou qualidade, mesmo sem utilizar qualquer forma de mensuração. Por outro lado, a ação é verificável se o Principal consegue, além de observá-la, provar o que observou a uma terceira parte responsável pela resolução de disputas contratuais. A distinção torna-se importante em relações de longo prazo entre o Agente e o Principal que permitam a interrupção ou a renegociação do contrato. Dentro de tal contexto, a observabilidade restringe o comportamento do Agente desde que a ameaça de punição, por interrupção ou por não cumprimento do contrato, seja crível.

$\mathrm{Na}$ literatura econômica, há autores que utilizam o termo risco moral em referência a situações tanto de informação oculta quanto de ação oculta (Hart e Holmstrom, 1987, Rasmusen, 1994 e Azevedo, 1996:15). A primeira tentativa de explicar o fenômeno do risco moral foi o trabalho de Arrow (1968) sobre o setor de seguros. Desde Arrow (1968), a expressão risco moral tem sido a terminologia utilizada para designar efeitos adversos que surgem em situações com contingências não observáveis, que necessitam de informação para o desenho de contratos eficientes. No presente estudo, emprega-se o termo para identificar somente situações de ação oculta, como proposto originalmente por Arrow.

Milgrom e Roberts (1992: 601) entendem risco moral como o comportamento oportunista pós-contratual que surge quando as ações requeridas ou desejadas sob o contrato não são livremente observadas, beneficiando a parte com informação privada. O comportamento oportunista do Agente torna-se mais comum quando o Principal não consegue monitorar e controlar as ações do Agente satisfatoriamente.

\footnotetext{
${ }^{5}$ A Teoria do Agente-Principal trata da relação entre duas partes, onde uma parte (Principal) delega obrigações à outra (Agente), em um ambiente onde a informação é assimétrica e as funções e interesses de cada parte são diferentes. A determinação do contrato ótimo entre o Principal e o Agente trata-se do objetivo central da teoria. A distinção entre custo de transação ex-ante e ex-post diferencia a ECT da Teoria do Agente-Principal, que adota racionalidade plena e somente custos ex-ante. $\mathrm{O}$ arcabouço teórico padrão é encontrado em Jensen e Meckling (1976), Fama (1980), Fama e Jensen (1983) e Jensen (1986).
} 
Qualquer modelo que apresente uma situação envolvendo risco moral possui informação completa e incerteza. Durante uma transação, o fenômeno de risco moral ocorre quando uma das partes tem a possibilidade de efetuar ações que interferirão na avaliação da transação pela contra-parte. A existência de assimetria de informação e o surgimento de interesses divergentes entre as partes são condições necessárias para o aparecimento do risco moral. Um fato importante que deve ser acrescentado consiste na impossibilidade da contra-parte conseguir monitorar adequadamente e/ou forçar o cumprimento dos termos contratuais nos quais a transação foi realizada.

$\mathrm{Na}$ situação envolvendo informação oculta, a informação é simétrica no momento do contrato, tornando-se assimétrica somente após sua assinatura, como no modelo de risco moral, o que não permite aos jogadores utilizar a informação privada para obter alguma vantagem decorrente de termos contratuais ineficientes sobre o outro.

Novamente, há imprecisão no uso do conceito na literatura. Alguns autores identificam a seleção adversa como um caso de informação oculta. A diferença é sutil, mas existe e é importante. Em situações de informação oculta, a ação do Agente é mais enfatizada do que a escolha do contrato, que o Agente aceita antes de adquirir informação privada. Sob seleção adversa, o Agente obtém informação privada acerca do seu Tipo ${ }^{6}$ ou estado da Natureza antes de aceitar o contrato. A ênfase, no caso, recai em qual contrato será aceito pelo Agente.

A informação pode tornar-se incompleta em modelos de risco moral com informação oculta, embora seja completa no início do jogo. Tal situação é descrita na literatura que utiliza o conceito original de risco moral como um caso especial de seleção adversa. Um dos métodos de distinção dos problemas contratuais consiste na observação se o contrato foi estabelecido entre as partes antes ou depois que a informação tornou-se assimétrica e se as ações das partes envolvidas são de conhecimento comum. Embora a separação entre risco moral e informação oculta facilite a compreensão dos modelos, a maioria das situações reais envolve formas híbridas que contêm elementos de ambos problemas. 
Há diversas maneiras de controlar os problemas de oportunismo póscontratual. O aumento dos recursos destinados ao monitoramento e verificação da transação trata-se de uma forma efetiva de reduzir a assimetria informacional. Uma segunda forma consiste na introdução de uma estrutura de incentivos nos contratos, premiando o bom desempenho dos agentes. Normalmente, os esquemas de incentivos são estabelecidos pelo Principal na fase de elaboração do contrato para que as ações do Agente, que não são monitoradas perfeitamente, ocorram no sentido preferido pelo Principal. Deste modo, as partes envolvidas procuram antecipar os problemas de informação assimétrica que possam surgir após a assinatura do contrato. Por último, o aparecimento de conflitos de interesse entre a firma e os fornecedores podem ser eliminados por um processo de integração vertical. Apesar do risco moral e a informação oculta serem problemas distintos, os métodos empregados para reduzir o oportunismo das partes são idênticos.

\subsubsection{RACIONALIDADE LIMITADA E INCOMPLETUDE CONTRATUAL}

Segundo Simon (1972), o pressuposto de racionalidade limitada implica que os agentes econômicos não conhecem todas as soluções dos problemas, sendo incapazes de determinar todos os possíveis resultados e ordená-los perfeitamente segundo suas preferências. Sob a ótica dos contratos, tal fato significa que os agentes não conseguem desenhar soluções ótimas para todas as possíveis contingências com custos baixos.

Zylbersztajn (1996), salienta que a incompletude dos contratos surge tanto da racionalidade limitada quanto do elevado custo de obtenção da informação necessária para preencher qualquer lacuna contratual. Em tal situação, o surgimento de custos de transação associados ao desenho de contratos incompletos pode ocorrer em razão da existência de contingências não previstas

\footnotetext{
${ }^{6}$ Tipo de um jogador é o conjunto de estratégias, informações e função payoff que a Natureza escolhe para cada jogador no início de um jogo com informação incompleta.
} 
no momento de assinatura do contrato, elevado número de contingências, monitoramento e utilização do aparato legal para redigir o contrato.

A ocorrência de contratos incompletos deve-se a limitação cognitiva dos agentes, a incerteza associada à dificuldade de previsão de todos os eventos futuros relevantes ou, então, da deficiência institucional em prevenir o comprometimento das partes sobre certas variáveis (Brousseau e Fares, 2000). O surgimento de rendas apropriáveis oriundas do elevado grau de especificidade de ativos tornam os contratos passíveis de rompimento por uma das partes.

\subsection{QUEBRA CONTRATUAL}

Milgrom e Roberts (1992:137) entendem a quebra contratual como um problema pós-contratual, gerado por contratos incompletos e imperfeitamente especificados, que permite a exploração de eventuais falhas e lacunas pelas partes com o objetivo de obter alguma vantagem sobre a outra.

Conforme Schwartz (1992), a utilização de termos vagos ou ambíguos, a informação assimétrica (ex-ante ou ex-post), os elevados custos de elaboração do contrato completo e a desconsideração de aspectos relevantes da transação são os principais fatores que originam o contrato incompleto. Segundo a visão de Williamson (1996), um contrato é efetivamente incompleto se:

(1) Nem toda contingência futura relevante pode ser imaginada;

(2) Detalhes de alguma contingência futura são obscuros;

(3) Um entendimento comum da natureza das contingências futuras não pode ser alcançado;

(4) Um entendimento comum e completo das adaptações apropriadas das contingências futuras não pode ser alcançado;

(5) As partes são incapazes de concordar sobre qual evento contingente se materializou;

(6) As partes são incapazes de concordar que adaptações atuais para entender as contingências correspondam às especificadas no contrato; 
(7) Mesmo que ambas as partes estejam completamente informadas a respeito da contingência ocorrida e de adaptações que tenham sido feitas, uma terceira parte pode não ter conhecimento de ambas, gerando discussões custosas entre as partes bilateralmente dependentes.

Normalmente, o problema surge em relações que envolvam investimentos específicos com custos irrecuperáveis. Ativos altamente específicos potencializam a possibilidade de quebra contratual ao permitir que uma das partes não cumpra as obrigações contratuais na tentativa de extrair melhores termos do proprietário do ativo específico. A simples possibilidade de uma das partes sofrer um grande prejuízo ao não conseguir alocar o ativo para outro uso ${ }^{7}$, modifica a distribuição do poder de barganha entre as partes, desestimulando o comportamento oportunista da parte que realizou o investimento.

O término da relação contratual implica na perda de um fluxo futuro de quase-rendas ${ }^{8}$ pelo Agente. Ao requerer investimentos na produção de ativos específicos que forneçam taxas normais de retorno, o Principal cria quase-rendas. Em tal situação, a quebra contratual pode fazer o Agente incorrer em elevada perda de capital.

O problema não surgiria caso o contrato fosse completo. Em tal situação, as partes especificariam todas as possíveis circunstâncias que pudessem surgir e determinariam, para cada uma delas, o comportamento a seguir. A solução para o problema de quebra contratual nunca será total, em virtude da impossibilidade de elaboração de contratos completos. Assim, a utilização tanto de sistemas de incentivo quanto de instrumentos de garantia de execução dos contratos (salvaguardas, coerção e monitoramento) são formas usadas para reduzir o comportamento oportunista dos agentes, constituindo-se um importante mecanismo amortecedor do problema de incompletude contratual e suas conseqüências.

\footnotetext{
${ }^{7}$ Quando o investimento realizado no ativo é altamente específico não há possibilidade do proprietário do ativo específico recuperá-lo, proporcionando um prejuízo maior em decorrência da quebra contratual.

${ }^{8}$ Diferença entre o retorno de um ativo utilizado em uma transação específica e o retorno do uso alternativo.
} 
Falta, portanto, dimensionar e identificar as principais características das transações. Williamson (1985) procurou atribuir dimensões objetivas e de fácil observação de forma a facilitar a observação dos atributos das transações.

\subsubsection{ATRIBUTOS DAS TRANSAÇÕES}

Williamson (1985) sustenta que uma transação individual possui três atributos principais: freqüência, incerteza e especificidade de ativos. O custo de transação seria uma função do espaço $n$-dimensional formado por cada atributo, mantida constante a estrutura de governança criada para reduzir tais custos (Farina, Azevedo e Saes,1997:82). A existência de diferentes estruturas de governança é explicada pela variação dos atributos em cada transação. Loader (1996) salienta que a análise dos atributos deve considerar ambos os agentes envolvidos na transação.

O conjunto de atributos das transações tem sido foco constante de atenção de autores que desejam modificá-lo ou ampliá-lo. Milgrom e Roberts (1992:34) refinam a classificação inicial apresentada por Williamson (1985), acrescentando outras características às transações. Os autores propõem a inclusão dos atributos duração, visando captar a intensidade da transação no tempo; complexidade, em razão da presença de limites à racionalidade; dificuldade de medição de desempenho, visando ressaltar o problema informacional pós-contratual; e grau de inter-relacionamento com outras transações, que capta o grau de dificuldade de coordenação de diferentes transações. Finalmente, Grossman e Hart (1986) defendem a idéia de inclusão da estrutura de direitos de propriedade ao grupo de atributos principais quando for considerada uma restrição ao conjunto de escolhas de estruturas de governança.

As mudanças sugeridas pela literatura têm como papel mais importante enriquecer o debate sobre o assunto, pois não alteram a essência da proposta original de Williamson (1985). 


\subsubsection{FREQÜÊNCIA}

O atributo freqüência indica a quantidade de vezes que determinadas transações ocorrem entre os agentes, sendo uma medida da recorrência da transação. A relação contratual entre as duas partes é diretamente influenciada pelo atributo, uma vez que as diferentes freqüências de transação permitem o surgimento de formas contratuais alternativas.

A alta freqüência de transações gera a necessidade de utilização de estruturas de governança especializadas. O custo de transação de uma única transação não justifica a construção de um amplo sistema de controle e monitoramento. A repetição torna o custo de transação não desprezível, justificando a criação de formas mais complexas. O aumento da freqüência permite a diluição dos custos $^{9}$ de adoção de mecanismos mais complexos em razão do uso repetido do mesmo conjunto de especificações. Em suma, quanto maior a freqüência, menor será o custo fixo médio associado à coleta de informações e à elaboração de um contrato complexo que imponha restrições ao comportamento oportunista.

Um segundo aspecto importante associado freqüência das transações tratase da possibilidade de construção da reputação entre as partes. Zylbersztajn (2000) entende a reputação como a perda potencial do fluxo de renda futura por uma das partes em virtude do rompimento oportunista do contrato. A elevada freqüência da transação aumenta a quantidade de informação de uma parte sobre a outra, possibilitando o aparecimento de confiança mútua entre os agentes. A criação da reputação permite a redução das cláusulas de salvaguardas contratuais, diminuindo os custos de transação de elaboração e monitoramento dos contratos. O valor da reputação passa a desempenhar um papel restritivo ao comportamento oportunista dos agentes, na medida em que uma atitude oportunista poderia implicar a interrupção da transação e a conseqüente perda dos ganhos futuros derivados da troca.

\footnotetext{
${ }^{9}$ Custos de redação de contratos, coleta de informações relevantes, monitoramento e adaptação.
} 
Quanto maior o custo associado à perda de reputação, maior será o incentivo para a continuidade da relação. Em outras palavras, em transações recorrentes as partes podem desenvolver reputação, o que limita seu interesse em agir de modo oportunista para obter ganhos de curto prazo.

Por último, a freqüência possui importantes interfaces com os outros atributos das transações, viabilizando a realização de investimentos específicos e a redução da incerteza.

\subsubsection{INCERTEZA}

Em um ambiente de incerteza, os agentes não conseguem prever os acontecimentos futuros, aumentando o espaço para renegociação $e$, conseqüentemente, ampliando as possibilidades de perdas derivadas do comportamento oportunista das partes.

A literatura na NEI sobre incerteza envolve diferentes abordagens sobre o assunto. Koopmans (1957: 147), citado por Williamson (1996), distingue dois tipos de incerteza: primária e secundária. A incerteza primária, ou risco, diz respeito a um estado de situações contingenciais que está associada à variância de uma determinada distribuição de probabilidade. A incerteza secundária surge em razão da falta de comunicação não estratégica, sendo portanto totalmente não intencional.

Williamson (1996) propõe uma terceira classe de incerteza, denominada comportamental, visando ampliar a classificação de Koopmans e captar os aspecto estratégicos presentes nas transações. Por exemplo, as situações de dependência bilateral permitem o aparecimento da incerteza comportamental. North (1990) apresenta uma forma alternativa para compreensão da incerteza. Segundo North, a incerteza refere-se ao desconhecimento de evento futuros, desassociando-a da definição de uma distribuição de probabilidade. Por último, Milgrom e Roberts (1992) discutem o aspecto informacional da incerteza. Segundo os autores, a incerteza emergiria em relações contratuais com informação incompleta e assimétrica. 
A importância do atributo incerteza na ECT está presente na determinação das estruturas de governança que melhor se adaptem à variação dos eventos. É um atributo que mostra com clareza a incompletude contratual, estando diretamente associado ao pressuposto comportamental de racionalidade limitada. A impossibilidade de previsão de situações futuras que alterem os custos transacionais impede o correto desenho contratual de cláusulas de salvaguardas em virtude do desconhecimento ex-ante de tais contingências.

\subsubsection{ESPECIFICIDADE DE ATIVOS}

A especificidade expressa a dimensão do valor do ativo. Considera-se um ativo específico quando o retorno associado a ele depende da continuidade da transação à qual é específico. Segundo Williamson (1985), consiste em um investimento especializado que não pode ser transferido para usos alternativos sem perda do valor produtivo. Quanto mais específico for um ativo, mais custosa será sua realocação para outra atividade.

A especificidade de ativos refere-se à perda de valor dos ativos transacionados no caso da transação não ser realizada ou quando houver quebra contratual. Trata-se da dimensão mais importante e crítica das transações, além de distinguir a ECT de outras abordagens teóricas. Se a especificidade dos ativos for nula, os custos de transação são negligenciáveis, não havendo necessidade de controle sobre a transação.

Quanto maior a especificidade envolvida na transação, maior o risco e o problema de adaptação e, conseqüentemente, maior o custo de transação. A adaptação inadequada implica em ineficiência ao gerar maiores custos de transação ex-post (Azevedo, 1996). À medida que as características específicas do produto aumentam, crescem os custos de informação, adaptação e transporte das transações envolvendo o produto. A alta especificidade implica que o agente realizou um elevado investimento específico para a concretização da transação, que não poderá ser totalmente recuperado caso a transação não ocorra. 
Os ativos podem apresentar seis tipos distintos de especificidade que foram identificados por Williamson (1991:281): locacional, físico, capital humano, dedicado, marca e temporal. A primeira categoria refere-se a transações que devem ser realizadas em locais definidos, caso contrário, o ativo perderá valor. $A$ segunda categoria é representada por bens específicos para a realização de determinada tarefa, como, por exemplo, uma máquina específica para produzir determinado componente. A especificidade de capital humano refere-se ao conhecimento específico acumulado pelo indivíduo na atividade desenvolvida. A quarta categoria, ativos dedicados, envolve a realização de investimentos discretos para atender um cliente específico. A quinta forma de especificidade reflete a percepção do consumidor a respeito de um ativo intangível. A marca é um nome específico usado para distinguir o produto de determinado vendedor que necessita de investimentos específicos para ser criada. O último tipo descreve ativos que devem ser usados em uma determinada seqüência ou período de tempo, associando o fator tempo à perda de valor do ativo. A especificidade temporal é importante no caso de produtos agrícolas em virtude da perecibilidade. A classificação proposta por Williamson (1991) não é completa, mas consegue englobar a maioria das possibilidades.

Os cinco primeiros tipos de especificidade criam uma relação de dependência bilateral. Em tal situação, ambas as partes envolvidas na transação não têm incentivos para o término do contrato, uma vez que investimentos específicos foram realizados.

A existência de ativos específicos pode construir uma forte ligação entre os agentes em virtude da geração de quase-rendas apropriáveis. Os ativos específicos possibilitam o surgimento de quase-renda quando empregados corretamente nas transações em que são específicos, por apresentarem valor superior em tais situações. A barganha pela apropriação da quase-renda entre as partes, torna tais transações semelhantes a situações de monopólio bilateral. O conflito gerado pela disputa pode levar ao surgimento de problemas de adaptação e, portanto, ao aparecimento dos custos de transação (Klein et al., 1978). 
A continuidade da relação torna-se uma fonte de valor adicionado gerando a dependência, unilateral ou bilateral, que incentiva o comportamento oportunista das partes. A utilização de salvaguardas contratuais torna-se necessária para viabilizar a transação e proteger as partes de eventuais custos ex-post.

Considerando a existência de oportunismo e contratos incompletos e na presença de ativos específicos, as organizações deverão responder criando estruturas que permitam a sobrevivência dos contratos no longo prazo (Zylbersztajn, 2000).

\subsubsection{FORMAS ORGANIZACIONAIS GENÉRICAS}

A estrutura de governança é função dos atributos das transações (especificidade de ativos, freqüência e incerteza); pressupostos comportamentais dos indivíduos (racionalidade limitada e oportunismo);e ambiente institucional (direito de propriedade, costumes e tradições). Williamson (1996:378) indica três formas organizacionais genéricas discretas que emergem da interação das variáveis para dar suporte às transações: clássica ou mercado; híbrida e hierárquica ou integração vertical. Segundo Klein (1998), as estruturas de governança podem ser descritas ao longo de um espectro, com mercado e hierarquia localizados nos pólos. As formas resultantes diferem entre si quanto ao custo de transação e dimensões (incentivo, controle e adaptação). A figura 2 representa a estrutura analítica da ECT.

A forma de mercado possui um grande número de agentes anônimos em cada lado da transação. Os preços de mercado proporcionam elevados incentivos para explorar oportunidades lucrativas, com os agentes preparados para se adaptar as mudanças de circunstâncias.

$\mathrm{Na}$ forma hierárquica, os agentes estão no interior do mesmo empreendimento e são sujeitos a controles. A hierarquia oferece grande proteção aos investimentos específicos e fornece mecanismos relativamente eficientes de resposta às mudanças onde a adaptação coordenada é necessária (Klein, 1998: 16). Entretanto, quando comparada com estruturas descentralizadas, a hierarquia 
fornece incentivos fracos aos gerentes para a maximização do lucro e incorre em custos burocráticos mais elevados.

FIGURA2: ESTRUTURA ANALITICA DA ECONOMIA DOS CUSTOS DE TRANSAÇÃO

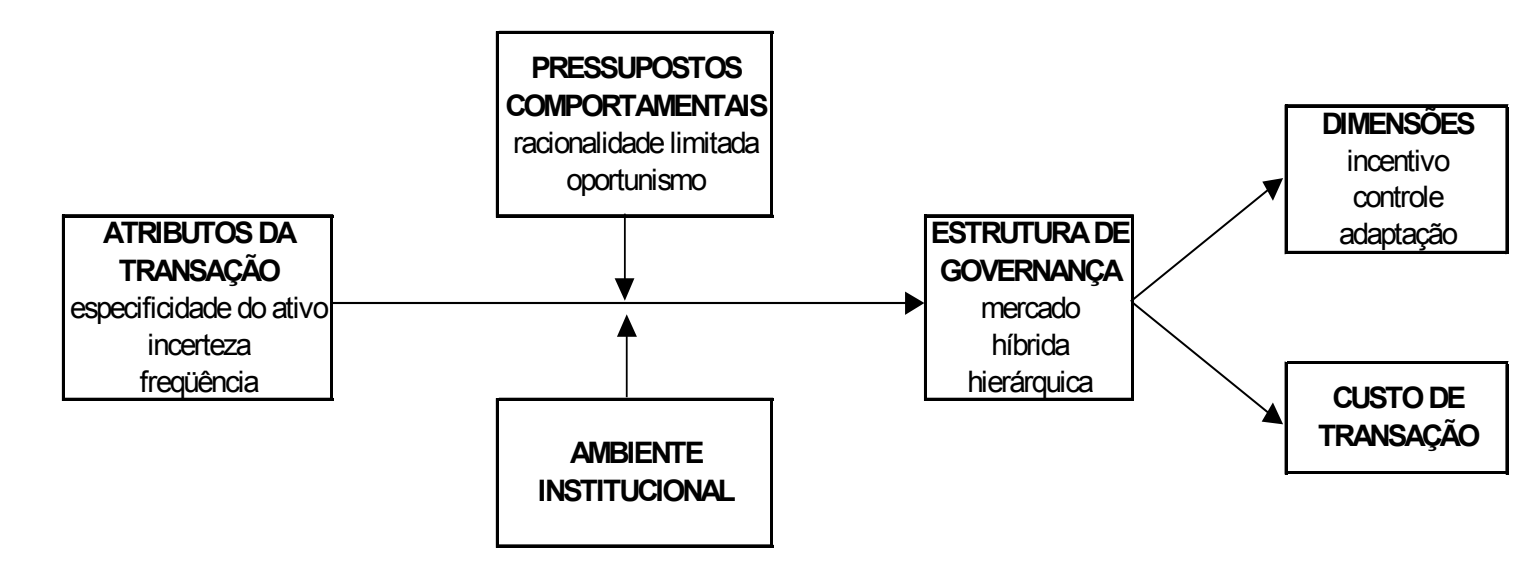

Fonte: Elaboração do autor

Uma análise comparativa das formas polares realizada por Azevedo (1996), considera como primeira distinção os aspectos tecnológicos. O mercado é mais eficiente que a hierarquia em tal aspecto, uma vez que tira proveito de forma mais veemente das economias de escala estáticas, economias de escopo e vantagens decorrentes da agregação de demandas não-correlacionadas. Uma segunda distinção está localizada na estrutura de informação. Em situações com custos de coleta e processamento de informação, o mercado possibilita o uso imediato da informação, enquanto a hierarquia necessita transmiti-la até a instância decisória. A terceira distinção é organizacional e refere-se à natureza dos contratos em cada estrutura de governança. A ECT aceita a proposição de Alchian e Demsetz (1972), que consideram a firma como um complexo de contratos, mas rejeita a afirmação que não existem diferenças entre contratos internos e externos à firma. Ao distinguir o contrato interno do externo, a ECT está distinguindo mercado de hierarquia.

Entre os casos polares, encontram-se formas organizacionais intermediárias, denominadas híbridas, onde ocorre a maior parte das transações (Zylbersztajn, 1995:70). A forma híbrida refere-se geralmente a relações de longo prazo com a manutenção da autonomia e concessão de salvaguardas específicas 
à transação. Jacquemin (1985:139) enfatiza que sob determinadas condições as formas intermediárias são capazes de reduzir os custos de transação que seriam incorridos caso a transação fosse realizada por meio do mercado. Similarmente, evita-se que determinados custos organizacionais ocorram caso a transação fosse completamente internalizada no interior da firma.

Segundo Williamson (1991:294), a forma híbrida não constitui simplesmente uma forma intermediária, pois possui uma racionalidade própria disciplinada e uma lógica que é revelada pelo dimensionamento e explicação das organizações desenvolvidas em seu interior.

Ménard (1996:156) define a forma organizacional híbrida como uma estrutura de governança especializada para lidar com uma dependência bilateral sem promover a integração. $O$ argumento de Ménard é que a dependência bilateral possui força suficiente para requerer coordenação estrita, mas não é suficientemente forte para justificar a integração completa. A existência de ativos específicos em uma transação estabelece uma forte ligação entre os agentes que permite o surgimento de quase-rendas. A continuidade da relação gera a dependência e favorece o comportamento oportunista desde que os ativos não possam ser redirecionados para outras atividades ou, então, quando os custos de redirecionamento dos ativos são extremamente elevados. Em tal situação, a concorrência não é mais um indicador suficiente do nível de eficiência, uma vez que a relação entre as partes tornou-se bilateral. O processo de transformação da relação contratual de competitiva para um monopólio bilateral recebe o nome na literatura de transformação fundamental.

Em geral, transações discretas (baixa freqüência) acontecem via mercado. Com a elevação do número de transações, o custo de adoção de estruturas de governança mais complexas, que permitam a coleta de informação e a elaboração e monitoramento dos contratos, torna-se viável. North (1990) ressalta que o mercado "spot" também pode ser utilizado em transações com alta freqüência quando o efeito reputação é importante. Na ausência de especificidade de ativos o custo de transação é nulo, fazendo com que a forma organizacional de mercado seja comparativamente eficiente. À medida que a especificidade cresce, maior 
controle sobre as transações é requerido, aumentando o estímulo para a adoção de formas hierárquicas.

\subsubsection{ANÁLISE ESTRUTURAL DISCRETA}

Uma vez descrita a transação e a estrutura de governança adotada pode-se realizar a análise estrutural discreta comparada, na qual se alinham os atributos das transações com as estruturas de governança adotadas (Farina, 1998). O termo análise estrutural discreta (AED) foi introduzido no estudo comparativo de organizações econômicas por Simon (1978). Como Simon observou, a comparação de estruturas alternativas discretas pode ser feita sem um aparato matemático complexo.

Além de não existir uma maneira satisfatória de caracterizar as organizações em termos de uma variação contínua ao longo de um espectro, Williamson (1991:270) destaca os seguintes fatores que sustentam a idéia:

(1) As firmas são uma continuação dos mercados utilizando outros meios. A AED permite discernir e explicar os diferentes meios;

(2) Diferenças discretas na lei contratual sustentam e definem cada forma genérica organizacional;

(3) Análise marginal preocupa-se com refinamentos de segunda ordem (eficiência alocativa), negligenciando efeitos de primeira ordem (eficiência adaptativa).

O objetivo da AED consiste em comparar formas de governança alternativas sob o enfoque da eficiência, examinando como distúrbios no ambiente institucional afetam o equilíbrio da distribuição das transações.

A ECT possibilita a previsão da estrutura de governança a partir dos atributos das transações, não se tratando, portanto, de mera descrição de fatos estilizados (Farina et al., 1997). A implantação da ECT envolve uma avaliação institucional comparativa de alternativas institucionais discretas (do contrato de mercado clássico às organizações hierárquicas centralizadas). Os custos de transação podem ser avaliados ao comparar-se diferentes instituições. Eventuais 
discrepâncias entre as estruturas de governança esperadas e observadas podem indicar uma importante fonte de problemas de coordenação.

\subsubsection{ATRIBUTOS DE GOVERNANÇA}

As formas de governança genérica diferem quanto a três atributos: incentivo, controle e adaptação. A intensidade do incentivo avalia o grau de apropriação de receita líquida associada ao esforço e às decisões de uma parte. $O$ controle fornece o suporte necessário para que planos estratégicos sejam desenvolvidos e informações sejam coletadas e processadas, permitindo avaliar o desempenho das partes. Os instrumentos de incentivo e controle utilizados variam entre as formas de mercado, híbrida e hierárquica.

A adaptação consiste na capacidade dos agentes envolvidos na transação reagirem a uma perturbação do meio ambiente. Williamson (1991: 278) utilizando as idéias de Hayek (1945) e Barnard (1938) distingue dois tipos de adaptação: autônoma e cooperativa. A adaptação autônoma corresponde à visão de Hayek (1945:527) em que os preços são parâmetros suficientes para a escolha dos indivíduos. A adaptação cooperativa corresponde à visão de Barnard (1938), que se refere a situações de dependência bilateral entre as partes, necessitando de investimentos em mecanismos que coordenem as ações dos agentes na tentativa de promover a solução cooperativa no processo de adaptação. A presença de especificidade de ativos determina a existência de dependência bilateral e, conseqüentemente, a necessidade de adaptação do tipo cooperativa, caso contrário, a adaptação autônoma prevalecerá no sistema econômico. Uma maneira de determinar a eficiência da forma organizacional consiste na avaliação da capacidade de reação às mudanças. O Quadro 1 associa a cada forma de governança genérica, intensidade dos atributos de incentivo, controle e adaptação.

A forma de mercado apresenta incentivos fortes, mas com pouco controle sobre a transação. Ao mesmo tempo, é mais eficiente para implementar adaptações autônomas devido ao elevado incentivo e pela capacidade de utilizar as informações imediatamente com custo baixo. 
A hierarquia apresenta poucos incentivos e forte sistema controle sobre as transações, o que favorece a implementação de adaptações cooperativas. A intensidade dos incentivos se reduz na forma hierárquica em razão da impossibilidade de intervenção seletiva.

QUADRO 1: DISTINÇÃO DAS FORMAS DE GOVERNANÇA

\begin{tabular}{|c|c|c|c|}
\hline \multirow{2}{*}{ ATRIBUTOS } & \multicolumn{3}{|c|}{ ESTRUTURA DE GOVERNANÇA } \\
\cline { 2 - 4 } & Mercado & Híbrida & Hierárquica \\
\hline $\begin{array}{c}\text { Intensidade do } \\
\text { Incentivo }\end{array}$ & forte & médio & fraco \\
\hline $\begin{array}{c}\text { Controle } \\
\text { Administrativo }\end{array}$ & fraco & médio & forte \\
\hline $\begin{array}{c}\text { Adaptação } \\
\text { Autonoma }\end{array}$ & forte & médio & fraco \\
\hline $\begin{array}{c}\text { Adaptação } \\
\text { Cooperativa }\end{array}$ & fraco & médio & forte \\
\hline
\end{tabular}

Fonte: Adaptado de Williamson (1991:281)

Como apontado por Azevedo (1996:64), "conforme a dimensão de uma transação, incentivo ou controle serão mais ou menos importantes. Isso se dá porque as adaptações requeridas por cada uma das transações serão diferentes, demandando características distintas das estruturas de governança."

Por fim, a forma híbrida caracteriza-se por incentivos semifortes, um grau intermediário de controle administrativo e permite que os dois tipos de adaptação ocorram, localizando-se entre os dois casos polares anteriores. O estabelecimento de uma estrutura que permita a negociação bilateral entre as partes trata-se da principal característica da forma híbrida. A negociação entre as partes baseia-se em critérios precisos que resultam em compromissos informais sustentados pela própria dinâmica da relação ou pela existência de mecanismos de governança coletivo que regulam as transações entre os indivíduos (Brousseau e Fares, 2000).

A determinação da forma organizacional mais adequada apoia-se no tradeoff entre incentivo e controle, de modo que a escolha de maior incentivo implica necessariamente na perda de controle, e vice-versa. O movimento do mercado 
para hierarquia acarreta na escolha entre fortes incentivos e propriedades adaptativas do mercado ou salvaguardas e propriedades coordenativas da firma.

Cada forma genérica de governança é sustentada por diferentes formas contratuais para atender as especificidades de cada transação.

\subsubsection{FORMAS CONTRATUAIS}

Zylbersztajn (1995) salienta que os contratos apresentam custos associados ao desenho, implementação, monitoramento e resolução de disputas. Um entendimento mais profundo da natureza do contrato emergiu com ênfase na regra legal associada à análise de formas discretas de contrato, preocupando-se mais com a finalidade contratual.

Como observado por Macneil (1978), qualquer sistema de lei contratual tem como propósito principal facilitar a troca. Objetivando estabelecer uma ligação teórica com a ECT, Williamson (1991:271) utiliza a classificação proposta por Macneil $(1974,1978)$ que diferencia os contratos em clássico, neoclássico e relacional.

O primeiro tipo, contrato clássico, aplica-se a transações discretas ou descontínuas, não restando ligações com os períodos anteriores. Os agentes são desconhecidos, de forma que não existe nenhuma relação de dependência entre eles, sendo semelhante às transações descritas pela abordagem tradicional da teoria econômica. A natureza do acordo é cuidadosamente delimitada e aspectos mais formais governam quando termos formais e informais são contestados. Por último, a participação de terceira parte é desencorajada (Macneil, 1978:864). O contrato clássico sustenta a forma organizacional genérica de mercado.

O segundo tipo, contrato neoclássico, refere-se a transações com reflexos no longo prazo. Aplica-se a contratos em que as partes mantêm autonomia, mas são bilateralmente dependentes. Os agentes migram do contrato clássico para o neoclássico devido à incapacidade do primeiro em promover adaptações eficientes a situações não previstas. A forma neoclássica de contrato apresenta a flexibilidade necessária para preencher eventuais lacunas contratuais, facilitando a 
continuidade da relação. A assistência de terceira parte para a resolução de disputas e avaliação de desempenho é encorajada em situações de litígio entre as partes, implicando em dependência trilateral. Formas organizacionais híbridas são suportadas pelo contrato neoclássico.

O último tipo, contrato relacional, surge em situações nas quais a duração e a complexidade do contrato aumentam. Os contratos relacionais são aqueles que flexibilizam os termos iniciais, implicando em contínua capacidade adaptativa associada a mecanismos de solução de disputas (Zylbersztajn, 1996). Contrastando com o contrato neoclássico, que utiliza o acordo original como ponto de referência para as adaptações, a forma relacional utiliza como ponto de referência o desenvolvimento ao longo do tempo da relação, podendo ou não incluir o acordo original (Macneil 1978:890). No contrato relacional, o esforço de desenhar contratos completos é trocado pelo esforço de manter um sistema continuado e negociável. Formas organizacionais hierárquicas são as suportadas pelo contrato relacional.

A análise dos efeitos dos atributos das transações sobre a forma contratual que sustenta a transação fornece a ligação teórica com as formas organizacionais genéricas.

\subsubsection{ESTRUTURAS DE GOVERNANÇA}

Macneil (1978) não identifica claramente as dimensões críticas do contrato. Entretanto, a diversidade contratual pode ser explicada por diferenças básicas nos atributos das transações. A utilização de formas contratuais simples somente é justificada para estruturas simples, evitando custos de elaboração mais elevados e desnecessários.

Diferentes estruturas de governança emergem como resultado da variação da freqüência e da característica do investimento requerido para consumar a transação (Quadro 2) .Um ativo pode receber três formas de investimento: não específico, misto e idiossincrático. Williamson (1985) refere-se à transação sob 
elevado grau de especificidade de ativos como idiossincrática. Quanto maior for a especificidade, maior o custo necessário para modificar a função inicial do ativo.

QUADRO 2: ESTRUTURAS DE GOVERNANÇA E CONTRATOS

\begin{tabular}{|c|c|c|c|}
\hline \multirow{2}{*}{ FREQÜÊNCIA } & \multicolumn{3}{|c|}{ INVESTIMENTO } \\
\hline & Não Específico & Misto & Idiossincrático \\
\hline Casual & & \multicolumn{2}{|c|}{$\begin{array}{l}\text { Governança Trilateral } \\
\text { (contrato neoclássico) }\end{array}$} \\
\hline Regular & (contrato clássico) & $\begin{array}{l}\text { Governança Bilateral } \\
\text { (reputação e } \\
\text { monopólio bilateral) }\end{array}$ & $\begin{array}{c}\text { Governança } \\
\text { Hierárquica } \\
\text { (integração vertical) }\end{array}$ \\
\hline
\end{tabular}

A freqüência, que constitui a segunda dimensão da transação, pode ser casual, regular ou única. A garantia de uma relação contínua é necessária para encorajar investimentos em capital humano e equipamentos especiais.

O último atributo da transação, a incerteza, trabalha com a impossibilidade de prever todos os eventos possíveis e com a incapacidade de determinar as informações mais relevantes quanto à elaboração do contrato. Objetivando simplificar a análise, Williamson (1985) assume que a incerteza está presente em grau intermediário e focaliza inicialmente nas características do investimento realizado no ativo e na freqüência da transação.

A forma de mercado trata-se da estrutura de governança mais importante para transações não específicas, tanto casuais quanto regulares. A governança de mercado torna-se efetiva no caso de transações recorrentes em virtude das partes utilizarem a própria experiência na decisão de continuar ou não a relação comercial. Quando a freqüência é casual, o agente não pode utilizar a experiência própria como garantia contra o oportunismo, podendo, entretanto, utilizar a experiência adquira por outros agentes. A estrutura de governança de mercado pode ser caracterizada pela falta de compromisso de longo prazo, contratos simples e completos e um papel central e dominante do mecanismo de preços 
(Brousseau e Codron, 1997). Sendo os bens e produtos padronizados, a transferência de informação entre os agentes fornece incentivos para as partes comportarem-se de forma responsável. O formato de contrato clássico é o mais adequado para a governança de mercado.

A governança trilateral está presente em dois tipos de transações: casual misto e casual idiossincrático. Implica a necessidade de arbitragem para resolução de disputas e avaliação de desempenho. Tendo ocorrido a transação trilateral, há um forte incentivo para que as partes não ajam conforme acordado anteriormente. O comportamento oportunista surge em virtude da ocasionalidade das transações. A realização de investimento especializado busca gerar custos de oportunidade menores do que os custos obtidos com usos alternativos. A existência de terceira parte é necessária para que os contratos sejam cumpridos e para solucionar eventuais disputas entre as partes. A forma contratual neoclássica é a mais adequada para sustentar a governança trilateral.

$\mathrm{Na}$ governança bilateral, a autonomia das partes é mantida, ocorrendo em transações freqüentes tanto do tipo misto quanto idiossincrático. A situação requer estruturas de governança bem específicas em virtude das transações não serem padronizadas, mas freqüentemente realizadas. As partes consideram a continuidade da relação comercial importante, permitindo a formação de confiança institucional ou pessoal. No caso de ajustamentos e de falta de consenso no acordo, alguns problemas poderão surgir, deixando as partes ainda parcialmente dependentes da forma de mercado. O contrato relacional é o mais adequado para tal situação.

Por último, governança hierárquica ou organização interna, surge em transações não padronizadas altamente idiossincráticas, com ativo humano e físico requerido altamente especializado, e ocorrem regularmente. Em tal situação, a transação é totalmente removida do mercado e organizada dentro de uma firma. Economia de escala podem ser obtidas por meio da cooperação entre os agentes. Novamente, a forma contratual relacional é a mais adequada para sustentar tais transações. 


\subsubsection{FORMA ANALÍTICA REDUZIDA}

Williamson (1991:284) propôs uma forma analítica reduzida para comparar as diferentes formas organizacionais, definindo para cada uma delas uma função custo de governança que utiliza como parâmetros os atributos da transação e os elementos do ambiente institucional. A especificidade de ativos (k) é escolhida como variável endógena ao modelo, enquanto os demais parâmetros, atributos da transação restantes e elementos do ambiente institucional, formam um vetor de variáveis exógenas $(\theta)$ ao modelo. Assim, no modelo genérico proposto por Williamson (1991), a escolha da forma organizacional eficiente é função da especificidade dos ativos envolvidos, tendo como objetivo central comparar a eficiência relativa ${ }^{10}$ de diferentes estruturas de governança. Williamson (1991:283) impõe duas restrições as funções genéricas de custos de governança das formas organizacionais de mercado, $M(k, \theta)$; híbrida, $X(k, \theta)$; e hierárquica $H(k, \theta)$.

(1) $M(0, \theta)<X(0, \theta)<H(0, \theta), \quad \forall \theta \in R^{n}$;

(2) $\quad M^{\prime}>X^{\prime}>H^{\prime}>0$. Onde $n$ é o número de variáveis exógenas.

A primeira desigualdade reflete o fato que os custos burocráticos (ou controles administrativos) são maiores na hierarquia do que no mercado, uma vez que, em situações onde a especificidade de ativos é insignificante a adaptação autônoma prevalece. A forma híbrida localiza-se entre as formas polares com respeito a incentivo, adaptação e controle (Quadro 1).

A segunda desigualdade mostra que a derivada da função custo em relação a $k$ é positiva para todas as formas organizacionais, indicando que a especificidade de ativos cria dependência bilateral, aumentando os custos de governança sobre a transação. Assim, conforme aumenta a especificidade de ativos, aumenta a dependência bilateral e a necessidade de controle, aumentando relativamente mais os custos da forma de mercado.

\footnotetext{
${ }^{10}$ Ver seção 2.1.5.
} 
O gráfico 1 apresenta a relação entre os custos de governança de cada forma organizacional e a especificidade de ativos, mantido constante o vetor de variáveis exógenas $(\theta)$ e utilizando as restrições impostas pelo modelo.

A especificidade $k_{1}$ representa a situação que os agentes são indiferentes entre as formas de mercado e híbrida. Similarmente, na especificidade $k_{2}$ os agentes são indiferentes entre as formas híbrida e hierárquica. A curva envelope é formada pela junção de trechos das curvas de custos de mercado (entre 0 e $k_{1}$ ), híbrida (entre $k_{1}$ e $k_{2}$ ) e hierárquica (maior que $k_{2}$ ), contém os pontos que refletem a escolha ótima da forma organizacional.

\section{GRÁFICO 1: CUSTO DE GOVERNANÇA E ESPECIFICIDADE DE ATIVOS}

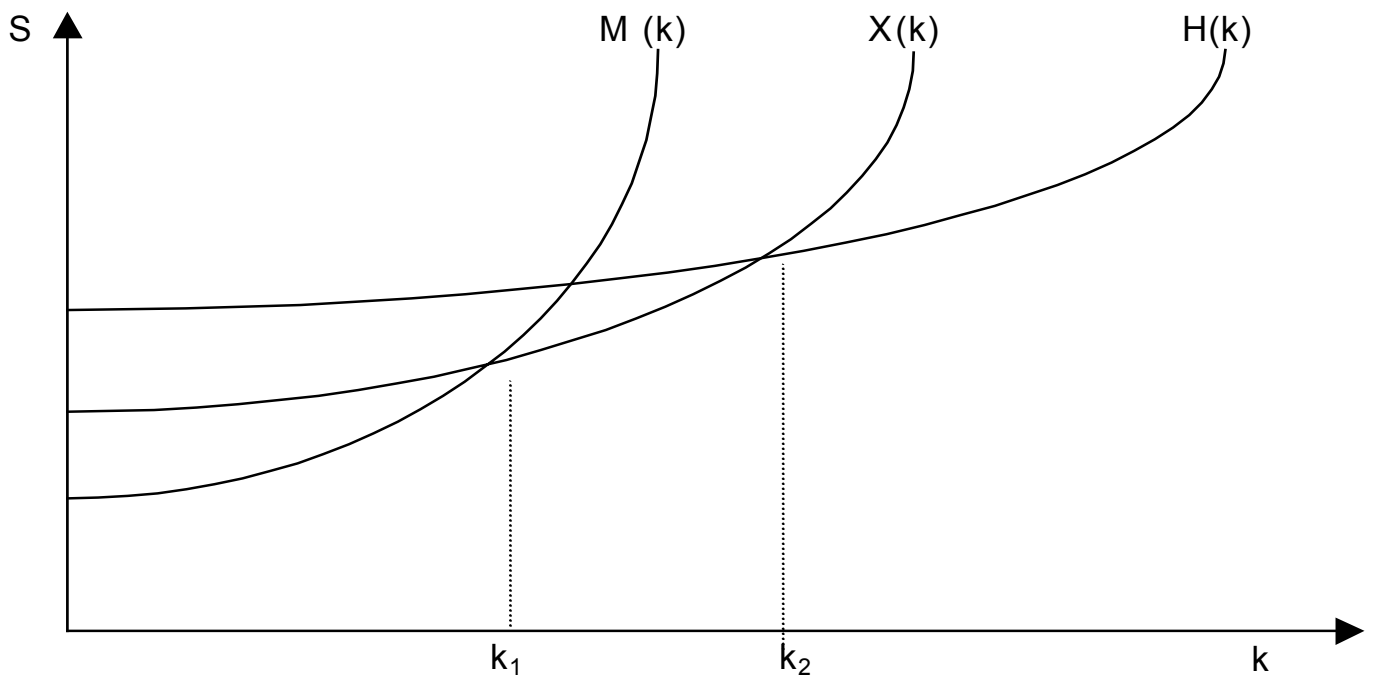

Fonte: Williamson (1991:284)

A forma analítica reduzida permite a integração das abordagens do Ambiente Institucional e das Estruturas de Governança, utilizando as variáveis exógenas do ambiente institucional para analisar modificações nas distribuições de equilíbrio das transações provocadas por alterações nos parâmetros institucionais. 


\subsection{AMBIENTE INSTITUCIONAL}

Firmas, mercados e relações contratuais são importantes instituições econômicas, sendo o produto evolucionário de uma série de inovações organizacionais. Somente admitir que os detalhes microanalíticos da organização são importantes não é suficiente. Os aspectos estruturais evidentes das formas organizacionais também precisam ser identificados, investigados e associados a conseqüências econômicas de uma maneira sistemática.

Como descrito por Coase (1988), o conjunto de instituições econômicas, políticas e sociais que fornece condições para que os custos de transação sejam baixos tem o papel central de viabilizar a existência de mercados de produtos e fatores. North (1994) acrescenta que o desempenho econômico é função das instituições e de sua evolução, e que somados à tecnologia utilizada determinam os custos de transação e produção. As instituições são restrições criadas pelos indivíduos para organizar a interação social, econômica e política, sendo constituídas de regras informais (costumes e códigos de conduta) e formais (leis e direitos de propriedade).

Existem pelo menos três horizontes de tempo a se considerar ao tratar com os efeitos da mudança institucional. Inicialmente, ocorrem movimentos de curto prazo na organização que, motivadas pelos ganhos de eficiência, movem-se para as formas de governança com menores custos. O segundo tipo são movimentos de longo prazo, cuja análise preocupa-se em compreender os fatores que alteraram as instituições. Finalmente, o processo de adaptação de normas informais é mais demorado que a adaptação de regras formais, aumentando substancialmente os custos de mudanças prolongadas, fato que explica parcialmente a baixa taxa de adaptações macroinstitucionais (Zylbersztajn et al., 2002).

O objetivo do trabalho não é analisar com profundidade a linha de pesquisa do Ambiente Institucional, cujo enfoque macroanalítico não é o mais adequado para a análise das transações envolvendo agentes econômicos no interior de uma cadeia produtiva. Pretende-se verificar como a mudança no ambiente institucional 
no vetor deslocamento afeta os custos das formas de governança. Inicialmente, a análise baseia-se no trabalho de Williamson (1991) sobre as implicações de alterações no direito de propriedade, lei contratual e incerteza, concentrando-se, em seguida, no papel do efeito reputação sobre as formas organizacionais.

\subsubsection{DIREITO DE PROPRIEDADE}

A literatura teórica a respeito do direito de propriedade é bastante rica e extensa, destacando-se os trabalhos de Alchian (1961), Demsetz (1967), Furubotn e Pejovich (1972,1974), De Alessi (1980) e Barzel (1989). O objetivo da tese é somente apresentar de maneira simplificada os conceitos básicos sobre o assunto e estabelecer uma ligação com o modelo desenvolvido anteriormente por Williamson (1991).

Pela visão de Demsetz (1967:347) os direitos de propriedade são um instrumento da sociedade e derivam sua importância do fato de ajudar o indivíduo a formar expectativas que ele pode manter em seu trato com os outros. As expectativas são expressas pelas leis, costumes e moral da sociedade. Uma definição mais genérica foi formulada por Furubotn e Pejovich (1974). Segundo os autores, o direito de propriedade consiste de três elementos:

(1) O direito de usar um ativo;

(2) O direito de apropriação de retornos sobre o ativo;

(3) O direito de alterar a forma e a essência do ativo.

Por fim, a proposta de Eggertsson (1990) considera que os direitos de propriedade são definidos por normas sociais e regras formais. A relevância depende de quão bem os direitos de propriedade são reconhecidos e coagidos pelos outros membros da sociedade.

A análise de Williamson (1991:287) preocupa-se essencialmente com as alterações no direito de propriedade ocasionadas pela expropriação governamental e pela expropriação comercial. O primeiro tipo está diretamente associado a questões de compromisso confiável (credible commitments). A falta 
de credibilidade do Governo em garantir o compromisso firmado com a sociedade sobre o direito de propriedade eleva o risco de investimentos em ativos imóveis e duráveis. Se a durabilidade e a imobilidade não estão correlacionadas com a especificidade de ativos, os custos de transação para todas as formas de governança do setor privado crescem junto com o aumento do risco de expropriação. Em tal situação, alterações nos valores de $k_{1}$ e $k_{2}$ serão imperceptíveis ou não ocorrerão.

O segundo tipo, a expropriação comercial, está associado à apropriação e dissipação de conhecimento especializado e informação por rivais, compradores e fornecedores. Como exposto por Williamson (1991:289), se os investimentos em conhecimento não forem efetivamente protegidos, o incentivo ex-ante de realizar tais investimentos é prejudicado e o incentivo ex-post de embutir tais investimentos em estruturas de governança protetoras torna-se elevado. Assim, quando o risco de expropriação cresce, o custo do contrato híbrido aumenta comparativamente ao hierárquico. Em tal situação, as curvas de mercado e híbrida deslocam-se para cima, de modo que $\mathrm{k}_{1}$ permanece praticamente inalterado e $\mathrm{k}_{2}$ desloca-se para a esquerda.

\subsubsection{LEI CONTRATUAL}

Alterações no regime de lei contratual modificam as curvas de custos de governança relevantes, permitindo a avaliação da mudança institucional. Uma melhora na forma do contrato neoclássico desloca a curva de custo híbrida para baixo, especialmente com os valores mais elevados de especificidade de ativos, em razão da redução dos custos de transação. O efeito da melhoria consiste no aumento do uso da forma híbrida quando comparada com a forma hierárquica.

Outra forma de modificação na lei contratual sugerida por Williamson (1991:290), refere-se ao aumento da vontade das cortes de justiça em litigar disputas técnicas nas firmas, que desloca a curva de custo hierárquico para cima e $k_{2}$ para a direita. Novamente, a forma híbrida é favorecida em detrimento a forma hierárquica. 


\subsubsection{INCERTEZA}

A elevação da incerteza pode ocorrer em razão do aumento do número de distúrbios, com a manutenção da mesma distribuição de probabilidade de distúrbios, e quando os distúrbios tornam-se mais conseqüências. O efeito geral do aumento da freqüência dos distúrbios é a redução da eficiência nas formas de mercado e hierárquica. A adaptação na forma híbrida requer mais tempo, pois envolve consenso mútuo entre as partes. $O$ aumento da freqüência na forma híbrida fará a curva de custo deslocar-se para baixo. Como descrito por Williamson (1991:292), "se um aumento na variância do distúrbio crescer uniformemente, os benefícios associados com cada adaptação de sucesso podem novamente ser avaliados por meio dos efeitos sobre a eficácia". Assim, o aumento da variância afeta o modo híbrido de forma adversa.

\subsubsection{EFEITO REPUTAÇÃO}

As primeiras referências teóricas a respeito de reputação recaem na literatura de organização industrial sobre competição imperfeita. A existência de contratos incompletos e/ou assimetrias informacionais trata-se de requerimentos básicos para o surgimento de qualquer sistema de reputação. $O$ fato da informação ser incompleta trata-se de uma condição necessária para analisar o surgimento do efeito reputação. Ao mesmo tempo, precisa existir uma quantidade de informação suficiente para que os agentes envolvidos na transação possam avaliar o comportamento passado das contrapartes.

A reputação aumenta a quantidade de informação disponível no instante de concretização da transação ao garantir que um conjunto de promessas sobre determinadas características do bem ou serviço transacionado torne-se consistente ao longo do tempo. Trata-se de uma relação extremamente frágil entre os agentes envolvidos, sendo passível de perda por qualquer movimento errôneo. 
Em geral, a reputação não necessita da assistência de instituições especializadas, sendo efetiva somente quando é observada diretamente pelos agentes. Entretanto, em grandes comunidades comerciais, a observação da reputação torna-se problemática devido à impossibilidade de um indivíduo conseguir monitorar todas as transações diretamente.

Os mecanismos de reputação induzem à cooperação sempre que existam transações repetitivas envolvendo os mesmos agentes, sendo interpretado como cooperação benigna e não oportunística. A ruptura da transação de forma oportunista provoca a perda do valor descontado de um fluxo de rendas futuras que incentiva os agentes à cooperação (Zylbersztajn, 2000).

A teoria dos jogos trata a indução da cooperação ao considerar o surgimento de equilíbrio motivado por jogos repetitivos ${ }^{11}$. Resumidamente, em um jogo repetido, cada jogador tem a oportunidade de estabelecer uma reputação e encorajar o oponente a agir da mesma forma. A idéia central é que, se o indivíduo sempre joga da mesma maneira, seu oponente esperará que ele jogue do mesmo modo no futuro, e, assim, ajustará sua própria ação.

\subsubsection{RELAÇÃO ENTRE REPUTAÇÃO E FORMAS GENÉRICAS}

Williamson (1991:291) assume a existência de uma comunidade em que o efeito reputação funcione bem. O aperfeiçoamento da rede de difusão de informação está diretamente associado à melhoria nos mecanismos reputacionais, atenuando os incentivos ao comportamento oportunista entre os agentes. Em tal situação, o trade-off entre os ganhos de curto prazo e as perdas futuras de rendas precisa ser cuidadosamente avaliado pelos agentes. As formas organizacionais híbridas são suscetíveis a riscos maiores de comportamento oportunista nas transações. A melhora do efeito reputação entre firmas reduz o custo da forma híbrida deslocando $k_{2}$ para a direita, aumentando a prevalência de formas contratuais híbridas em relação à forma hierárquica.

\footnotetext{
${ }^{11}$ A abordagem padrão sobre reputação surgiu nos trabalhos de Kreps, Milgrom, Roberts e Wilson (1982), Kreps e Wilson (1982a) e Milgrom e Roberts (1982b)
} 
O efeito reputação também pode ocorrer nas formas hierárquicas. Se a reputação interna aumenta, o oportunismo gerencial é reduzido, permitindo a redução do custo da forma de governança hierárquica. Em geral, a utilização de arranjos contratuais formais prevê a aplicação de multa pelo não cumprimento do acordo.

O efeito reputação surge principalmente em situações onde predominam relações informais entre os agentes, desempenhando um papel importante ao tornar críveis as ameaças de punição. Entretanto, qualquer punição será custosa tanto ao punido quanto para o agente que pune, o que acrescenta a questão de quando se deve punir. Fudenberg e Tirole (1991), demonstram que quando a informação entre os jogadores é incompleta, o indivíduo pode desejar incorrer em custos de curto prazo para construir uma reputação quando ele é paciente e seu horizonte de tempo é longo. Por outro lado, quando o horizonte de tempo é curto, ele não teria interesse em investir na formação de reputação.

O tratamento de Milgrom e Roberts (1992) ressalta que o efeito reputação é potencializado pela difusão de informação entre os agentes por meio de redes de comunicação. Uma forma de interpretar uma rede é como uma relação contratual não hierárquica, na qual o efeito reputação é comunicado com rapidez e precisão para todos os agentes envolvidos. Assim, as partes envolvidas em transações em que o efeito reputação é aplicável podem tanto consultar a experiência própria quanto se beneficiar da experiência dos outros. 


\section{ORGANIZAÇÃO DA CADEIA PRODUTIVA}

A agricultura consiste na maior atividade produtiva do mundo, empregando um número trabalhadores maior que a soma de todas as outras ocupações existentes (International Food Information Council - IFIC, 1998). Somente 20 espécies de aproximadamente 250.000 espécies vegetais conhecidas são cultivadas com propósito de produzir alimentos (Barber, 1990). Uma tendência mundial refere-se ao crescimento da integração da agricultura com outros setores industriais da economia, aumentando a importância da eficiência das estratégias de coordenação vertical como fator determinante do desempenho da cadeia produtiva.

A organização da cadeia produtiva descreve a maneira como as atividades entre os agentes estão interrelacionadas e distribuídas. A partir da introdução do conceito de agribusiness por Davis e Goldberg (1957) e Goldberg (1968), o estudo das relações agroindustriais está centrado na análise sistêmica. A visão sistêmica trata-se de uma forma de análise de um conjunto de elementos relacionados e coordenados entre si que formam uma estrutura organizada.

De acordo com Churchmann (1972), na literatura de Teoria Geral dos Sistemas existem quatro visões diferentes sobre o real significado do enfoque sistêmico: a baseada na eficiência, a humanista, a científica e a experimental. $O$ presente trabalho não deve se aprofundar na diferenciação das abordagens, adotando o enfoque sistêmico baseado na eficiência, que propõe analisar as estruturas de governança avaliando sua capacidade de governar a transação, utilizando um critério de minimização dos custos de produção e transação.

A análise sistêmica apresenta como correntes principais o Commoditie System Approach (CSA) da tradição norte-americana da escola de Harvard e a Análise de Filiéres ${ }^{12}$ da literatura francesa em organização industrial. Enquanto o enfoque francês baseia-se em relações tecnológicas, o enfoque americano

\footnotetext{
${ }^{12}$ Morvan (1985) define filière como "uma seqüência de operações que conduzem à produção de bens, cuja articulação é amplamente influenciada pelas possibilidades tecnológicas e definida pelas estratégias dos agentes. Estes possuem relações interdependentes e complementares, determinadas pelas forças hierárquicas".
} 
enfatiza a coordenação (Zylbersztajn, 1995). Apesar de apresentarem metodologia e enfoque distintos, apresentam diversos aspectos em comum. Ambos vêm o processo produtivo como uma seqüência de ações dependentes, rompendo com a análise setorial tradicional ao focalizar as relações dos agentes de diferentes setores da economia a partir de determinado produto, incorporando a visão sistêmica. Apresentam um caráter descritivo e utilizam as relações contratuais para identificar e analisar as diferentes estruturas de governança. Por fim, as duas abordagens reconhecem que as atividades produtivas são promovidas pelas instituições em que estão inseridas, gerando uma importante ligação com a NEI. O arcabouço teórico da NEI preenche a lacuna deixada pelas duas teorias: o fato de não conseguir determinar o nível e a forma de coordenação vertical.

Entende-se a coordenação vertical como um arranjo institucional particular entre as unidades econômicas, que governa a maneira pela qual tais unidades cooperam. É relativa às estruturas de governança ordenadas em um contínuo, que tem nos extremos as transações no mercado spot e a integração vertical (Zuurbier, 1996).

De acordo com Farina e Zylbersztajn (1994), a coordenação vertical eficiente de sistemas agroindustriais trata-se de um dos determinantes da competitividade. A abrangência do conceito de competitividade é ampliada ao englobar toda a cadeia produtiva e sua organização, não se limitando mais à eficiência produtiva da firma individual. Quanto mais adequada for a coordenação entre os componentes do sistema, menores os custos de cada um individualmente, mais rápida a adaptação às modificações do ambiente institucional e menor o custo referente aos conflitos inerentes às relações de cliente e fornecedor. $\mathrm{O}$ enfoque sistêmico permite caracterizar a organização de sistemas de produção como estruturas eficientes de coordenação.

A combinação dos arcabouços teóricos da ECT e da Teoria de Organização Industrial permite incluir na estrutura analítica as decisões estratégicas dos agentes envolvidos na transação. Zylbersztajn e Farina (1998) entendem que tratamento contratual do sistema agroindustrial (SAG) permite aprofundar o conhecimento no interior da cadeia produtiva do processo de transmissão de 
informação entre os agentes e dos mecanismos de incentivo e controle necessários para sustentar as transações.

\subsection{COORDENAÇÃO DE SISTEMAS AGROINDUSTRIAIS}

A evolução recente do estudo dos sistemas agroindustriais está centrada na questão relativa à coordenação eficiente das cadeias produtivas. $\mathrm{O}$ conceito de sistemas agroindustriais envolve a análise de produtos isolados em um fluxo contínuo de relações contratuais desde a pesquisa até o consumidor final. Tratase de um conceito amplo, que engloba elementos do ambiente institucional, da cadeia vertical de produção e das organizações de suporte ao funcionamento das cadeias. Segundo Machado (2000:4) o termo SAG "embute a idéia de organização sistêmica e coordenada da cadeia produtiva agroalimentar. Compreende um conjunto de agentes econômicos, posicionados seqüencialmente antes, dentro e depois da atividade agrícola, responsáveis por diferentes etapas de produção, transformação e comercialização de um produto de origem agropecuária até o mesmo chegar ao consumidor final. Pode envolver muitas firmas, de indústrias diversas e ocupar diferentes espaços locacionais, até mesmo além fronteiras, sob regras institucionais de distintos países."

Farina e Zylbersztajn (1992) definem a cadeia produtiva como um subsistema de um SAG, que privilegia as relações entre agropecuária, indústria de transformação e distribuição, ao redor de um produto específico principal. A cadeia produtiva é entendida como uma sucessão de operações verticalmente organizadas de atividades produtivas desde a produção até o consumidor final.

O elevado grau de interdependência entre os setores produtivos industrial, agrícola, e de serviços faz com que a dinâmica individual de cada agente passe a influenciar diretamente todos os outros agentes da cadeia produtiva. A agregação das cadeias produtivas permite visualizar as relações tecnológicas e comerciais dos segmentos no interior do SAG, fornecendo os elementos necessários para o entendimento de sua dinâmica frente às mudanças técnicas, organizacionais e institucionais. 
O entendimento das cadeias produtivas como uma seqüência de ações permite avaliar cada ação ao longo da cadeia como um contrato entre os agentes. Os estudos recentes sobre coordenação vertical de Ménard (1996), Loader (1996), Philippe e Sauvée (1997) e Brousseau e Codron $(1997,2000)$ salientam que a ECT oferece um quadro analítico que permite compreender uma grande diversidade de arranjos contratuais. Especificamente, a ECT permite explicar a organização de sistemas produtivos como um conjunto de relações contratuais verticais, formais ou informais, que representam estruturas de governança intersegmentos que variam da governança de mercado à integração vertical (Farina et al., 1997).

O sistema agroindustrial de alimentos pode ser visto como um nexo de contratos informais e formais, cujo objetivo é fornecer estímulos, controles e agilizar o fluxo de informação ao longo de todos os segmentos do sistema. Dentro do contexto proposto pela NEI, o aparato metodológico da Teoria dos Contratos amplia o escopo analítico para o âmbito da cadeia produtiva em detrimento da visão centrada na agricultura, permitindo o tratamento das mudanças das relações entre os segmentos.

A análise das relações contratuais permite a visualização do modo como os agentes na cadeia produtiva dividem o risco associado à produção e à variabilidade do preço e a influência de ambos tanto na distribuição quanto no nível de qualidade do produto disponível no mercado. Segundo Klein (1992), os contratos são mecanismos criados para reduzir o risco de ruptura da transação, organizando os esforços comuns de produção de maneira a reduzir os eventos oportunistas e, conseqüentemente, o custo de transação.

Em razão da impossibilidade de elaboração de contratos completos, espera-se o surgimento de eventuais lacunas contratuais, exigindo a presença de meios para a resolução de pendências ocasionadas por litígios provenientes da disputa pela quase-renda associada à existência de ativos específicos. A definição de mecanismos de incentivos contratuais adequados ex-ante e de sistemas de monitoramento e coerção (enforcement) ex-post são aspectos fundamentais para a existência de um sistema de coordenação eficiente. 
Entende-se o sistema de coordenação como um conjunto de estruturas de governança que interligam os segmentos componentes da cadeia produtiva, onde a eficiência da coordenação é determinada pelas características das transações entre os segmentos e pelo ambiente institucional que as transações estão inseridas (Farina et al., 1997). Segundo Ménard (1995:118), a coordenação corresponde aos procedimentos que criam os planos compatíveis de unidades elementares ou obrigam à modificação dos planos iniciais ao longo do tempo.

\subsubsection{COORDENAÇÃO DAS FORMAS ORGANIZACIONAIS GENÉRICAS}

A coordenação da cadeia produtiva pode ocorrer de forma descentralizada e baseada no funcionamento do sistema de preços ou exigir a integração vertical. Entre os dois limites encontram-se os contratos que representam uma forma alternativa de coordenar fases sucessivas de um sistema. Os três tipos de formas organizacionais genéricas descritas por Williamson (1985) utilizam procedimentos distintos para promover a coordenação.

$\mathrm{Na}$ forma hierárquica (integração vertical), a coordenação é regulada por um sistema central de autoridade. A integração vertical pressupõe o controle hierárquico gerencial de estágios sucessivos tecnologicamente separáveis da produção (Williamson,1985). Envolve a fusão ou aquisição de dois ou mais estágios diferentes de uma cadeia produtiva, permitindo a redução da assimetria de informação das transações. A hierarquia interna desempenha o papel principal para garantir a coordenação da forma organizacional.

Utilizando o sistema de preços, a forma de mercado alcança os mesmos objetivos da forma hierárquica sem necessitar do uso de autoridade. A governança de mercado caracteriza-se pela falta de compromissos de longo prazo e a presença de contratos completos e simples. A coordenação dos diversos segmentos da cadeia produtiva ocorre de forma descentralizada e orientada simplesmente para o funcionamento do sistema de preços, que fornece fortes incentivos aos agentes na busca pelo lucro e possui grande capacidade adaptativa frente a eventuais mudanças circunstanciais. 
Entre os dois extremos localiza-se a forma híbrida (contrato), cuja coordenação é assegurada por mecanismos intermediários, associando diversos graus de autoridade, regras tácitas, incentivos e controles (Philippe e Sauvée, 1997). O modo híbrido surge da dependência bilateral forte o bastante para requerer uma coordenação estreita, mas não forte o suficiente para justificar uma integração completa (Ménard, 1996).

O leque de possibilidades contratuais varia desde acordos informais até relações formais com investimentos idiossincráticos. Os arranjos informais baseiam-se em vantagens recíprocas entre os participantes, sendo a confiança mútua a principal garantia para o cumprimento dos acordos. Já os diferentes tipos de contratos formais variam de acordo com a intensidade das restrições impostas.

Segundo a classificação proposta pela OECD (1997), pode-se distinguir os contratos em três tipos. O primeiro tipo, o contrato tradicional, define somente os requisitos básicos da transação: preço, qualidade, quantidade e data de entrega. O segundo tipo adiciona normas relacionadas aos procedimentos de produção que devem ser respeitadas pelos fornecedores, caso contrário, o comprador pode recusar o recebimento do produto. No terceiro tipo, o comprador adiciona o direito de fornecimento de algum insumo de produção. A participação dos dois últimos tipos de contratos na cadeia de FLV tem aumentado recentemente em razão da preocupação do varejo moderno em garantir a qualidade dos produtos comercializados no interior de suas lojas.

Em qualquer dos arranjos descritos anteriormente, a cooperação entre os agentes não é facilmente alcançada, uma vez que a racionalidade privada de busca do melhor resultado não leva necessariamente à racionalidade coletiva (Farina e Zylbersztajn, 1993). A colaboração entre as partes pode ser alcançada pelo comportamento cooperativo de barganha dos resultados (Grossman e Perry,1986 e Rubinstein, 1985) ou por meio do comportamento não-cooperativo entre os agentes.

Embora toda cadeia produtiva possa beneficiar-se com a cooperação, há grandes incentivos para o comportamento oportunista das partes, especialmente em situação que envolva investimentos específicos. A relevância do problema de 
coordenação acentua-se quando o contrato é realizado totalmente via mercado e menos importante na forma hierárquica. Na forma "intermediária" híbrida, a importância da coordenação está diretamente associada ao seu grau de integração vertical.

A decisão de escolher entre a estratégia de coordenação (mercado ou contrato) e de integração (hierárquica) baseia-se na expectativa dos agentes de obtenção de um resultado econômico superior. O desempenho diferenciado entre cadeias produtivas revela a existência de fatores específicos a cada cadeia, associados tanto às características tecnológicas quanto à dinâmica dos mercados consumidores.

Assim, a comparação dos custos de produção e transação determina qual a estratégia mais adequada para cada situação. A forma contratual de coordenação predominante na cadeia produtiva dependerá das características comportamentais dos agentes e dos atributos das transações, que variam caso a caso, exigindo o conhecimento detalhado da cadeia produtiva sob foco. O próximo passo é descrever detalhadamente as transações e os agentes da cadeia produtiva de frutas, legumes e verduras frescos.

\subsection{A CADEIA PRODUTIVA DE FLV}

O interesse no estudo da cadeia produtiva de FLV deve-se à percepção de que os contratos envolvendo produção, marketing, alianças estratégicas e fusões tornaram-se mais constantes entre os agentes da cadeia. O surgimento de novas relações no setor de FLV, baseadas na introdução de inovações organizacionais e logísticas, tem provocado o enfraquecimento das formas públicas tradicionais de abastecimento e o fortalecimento das novas estruturas privadas. A preocupação fundamental é averiguar como a mudança estrutural afeta as práticas comerciais de cada estágio do processo produtivo. Como afirma Dimitri (1999), a visualização de como qualquer mudança contratual ao longo da cadeia produtiva afeta os consumidores e os outros agentes envolvidos no processo produtivo não é trivial. 
As transações nas cadeias produtivas do setor de FLV incluem uma infinidade de artigos, como tomate, alface, maçã, banana, entre outros, com características próprias e particularidades inerentes à comercialização. Trata-se de um enorme conjunto heterogêneo de produtos, cujas transações ao longo da cadeia produtiva envolvem diversos agentes econômicos (produtores, empacotadores, transportadores, intermediários, atacadistas e varejistas). 0 presente estudo concentra-se nas atividades relacionadas à produção $e$ comercialização de produtos in natura. A descrição do segmento industrial de processamento e de seu relacionamento com supermercados e o segmento de refeições externas (restaurantes e fast-foods) não fazem parte do escopo da tese, uma vez que as transações apresentam atributos e agentes distintos. A figura 3 fornece uma visão genérica do segmento da cadeia produtiva de FLV em foco na presente tese.

FIGURA 3: CADEIA PRODUTIVA DE FRUTAS, LEGUMES E VEGETAIS FRESCOS

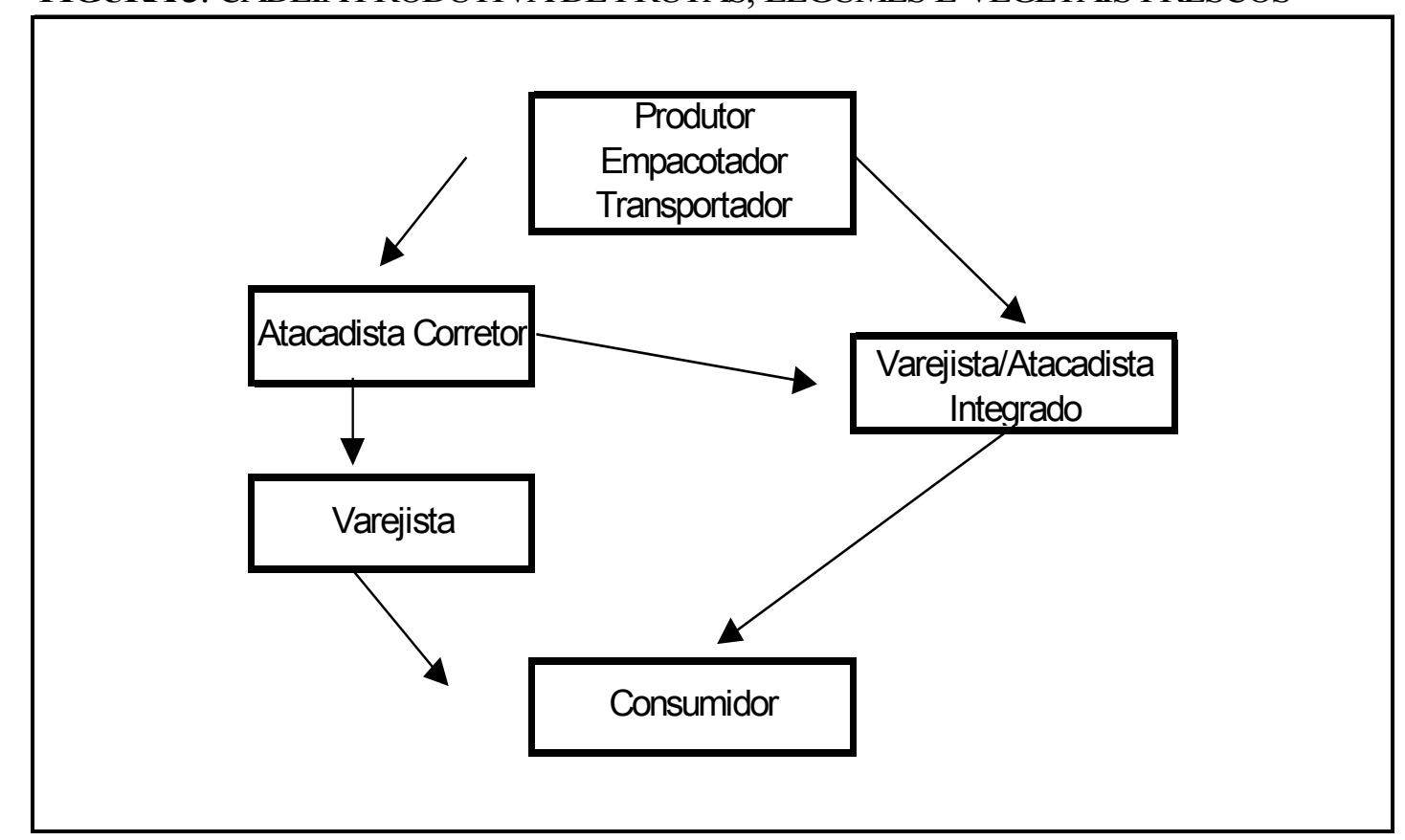

Fonte: Dimitri (1999)

O primeiro estágio consiste na produção e preparação (colheita, limpeza e seleção) do produto para o transporte, compreendendo produtor, empacotador e 
transportador. O diferente grau de integração vertical define a estratégia de coordenação escolhida pelos agentes. A separação completa das atividades provoca o aumento da perda ocasionada pelo manuseio e elevação do custo de monitoramento.

No segundo estágio acontece a primeira comercialização envolvendo produtores, corretores, atacadistas e varejistas. O produtor defronta-se com duas formas distintas de transação. Na primeira forma, a produção hortifrutícola pode ser diretamente vendida ao atacadista pelo corretor, ou, então, transportada à central de abastecimento, pública ou privada, para comercialização com o varejista e/ou atacadista. A escolha do fornecedor pelo varejista dependerá da qualidade disponível, preço, variedade disponível, reputação do vendedor e relacionamento de longo prazo entre os agentes. Na segunda forma, o produtor comercializa diretamente com o varejista. Com o objetivo de facilitar as transações e reduzir os custos, os grandes varejistas modernos têm investido na construção de depósitos e sistemas centralizados de compras. Tal estratégia de integração vertical parcial reduz o custo de transação, pois permite ao varejista adquirir os produtos em larga escala diretamente de poucos ofertantes, em vez de obter os produtos de vários pequenos ofertantes. A possibilidade do estabelecimento de uma relação de longo prazo com o produtor, evitando transações com o intermediário (atacadista e corretor), facilita as discussões a respeito da qualidade desejada do produto entre os parceiros comerciais.

No último estágio ocorre a transação do varejista com o consumidor final. Trata-se do ponto final para onde converge o fluxo dos produtos na cadeia produtiva. O consumidor desempenha papel fundamental na seleção dos atributos dos alimentos, determinando quais devem estar presentes nos produtos. A correta avaliação da preferência do consumidor permite a formulação de estratégias adequadas para conquistar novos clientes e manter a satisfação dos atuais consumidores. Compreender o comportamento do consumidor tornou-se um importante elemento estratégico para todos agentes da cadeia produtiva. 


\subsubsection{ALTERAÇÕES NO AMBIENTE COMPETITIVO}

O sistema de abastecimento mundial de alimentos encontra-se em fase de transformação decorrente da rápida internacionalização dos mercados, do desenvolvimento de novas tecnologias de informação e da otimização da logística de transporte. O processo é caracterizado por alterações significativas na base produtiva, que estão aumentando a interdependência entre os segmentos produtivos e elevando a competitividade. Se, no curto prazo, a estrutura de coordenação é determinada pelos atributos da transação, no longo prazo as estratégias individuais e coletivas podem definir o ambiente competitivo, institucional e tecnológico, modificando o formato da estrutura de governança eficiente (Machado, 2000).

Dentro de tal contexto, a organização da cadeia produtiva de FLV vem se alterando continuamente nos últimos anos, em razão de modificações na composição da demanda final, da elevação do potencial de oferta e do crescimento da importância das grandes cadeias varejistas modernas.

Sob a ótica da demanda, a conscientização sobre os benefícios de uma alimentação saudável tornou o consumidor mais exigente quanto ao nível de qualidade dos produtos frescos. A preocupação com os aspectos nutricionais dos alimentos aumentou a participação de FLV na cesta de consumo da população (Sarti e Machado,2000). Paralelamente, o aumento da participação da população feminina no mercado de trabalho provocou a diminuição do tempo médio disponível para a preparação das refeições em casa. Em suma, as principais alterações na composição da demanda final são provocadas pelo aumento do consumo de produtos que incorporam serviços, como conveniência e produtos que reduzem o tempo de preparação da refeição, e pelas novas exigências alimentares da população, decorrentes do crescimento econômico e da melhoria na disseminação de informações e conhecimento.

Sob a ótica da oferta, observou-se que a produção mundial de FLV aumentou 56\% entre 1980 e 1995 em países com vantagens comparativas relativas às condições climáticas e biofísicas para o plantio de tais produtos (FAO, 
1996). As mudanças na oferta são ocasionadas pelo desenvolvimento tecnológico de novas variedades de sementes e melhorias nas condições de estocagem, transporte e processamento. A produção em larga escala de FLV reduziu os preços dos produtos nas prateleiras, conquistando novos consumidores. Outro fator importante é a crescente implantação de sistemas de informação ao longo da cadeia produtiva, que permite redução dos custos das transações associados ao monitoramento pós-contratual e às salvaguardas pré-contratuais.

A crescente urbanização da sociedade moderna vem gradativamente alterando os hábitos de consumo da população quanto aos locais de aquisição de alimentos. A área ocupada pelo departamento de FLV aumentou significativamente no interior da cadeia varejista moderna (McLaughin e Perosio,1994). Por ser mais exigente que o setor varejista tradicional quanto às características qualitativas dos produtos comercializados, o varejo moderno conquista os clientes insatisfeitos de outros equipamentos varejistas. Ao mesmo tempo, por oferecer uma grande diversidade de produtos em um mesmo local, o varejo moderno atrai clientes que dispõem de pouco tempo para efetuar as compras. Os novos hábitos comportamentais dos consumidores vêm provocando um progressivo aumento da participação na comercialização de FLV pelo varejo moderno.

Os três fatores apontados estão induzindo os agentes da cadeia produtiva a procurarem novas formas de organização. Trata-se de um processo dinâmico que envolve redistribuição da renda entre os agentes da cadeia. Assim, é natural a expectativa pelo surgimento de grupos contrários às mudanças no sistema atual, tornando o processo de reestruturação uma questão também dependente de pressões políticas.

\subsubsection{CARACTERÍSTICAS GERAIS DOS FLV}

O segmento agropecuário apresenta uma grande diversidade de produtos que dificultam a análise genérica da organização das transações agrícolas. Brousseau e Codron (2000) separam os FLV em duas categorias. O primeiro 
grupo engloba produtos pouco perecíveis, vendidos em larga escala e com problemas logísticos negligenciáveis em razão da pequena distância entre os locais de produção e consumo, sendo, portanto, de fácil controle econômico. No segundo grupo encontram-se os produtos de gerenciamento mais complexo, como por exemplo, tomate, maça e alface, que constituem o foco de análise da tese por apresentarem problemas coordenativos importantes.

A produção de FLV possui algumas características específicas que influenciam diretamente a forma organizacional que promove a coordenação vertical da cadeia. A existência de grande diferenciação de atividades, agentes e custos de transação ocorre em virtude do grande número de produtores e da diversidade dos produtos. Ainda são culturas trabalho- intensivas, baseadas em pequenas empresas familiares, apesar do recente crescimento da utilização de sistemas de controle informatizados.

Algumas características específicas comuns a todos os produtos influenciam diretamente a organização de sua produção e distribuição. Dentro do conjunto de características, a perecibilidade é a mais relevante dos FLV (Masten, 1991; Zuurbier, 1998; Brousseau e Codron, 1997). A rápida deterioração exige que a manipulação e o armazenamento dos produtos necessite de cuidados especiais, como ambientes climatizados, veículos refrigerados, embalagens específicas e mão-de-obra especializada. A coordenação da cadeia está diretamente associada à questão de especificidade temporal que influencia os custos de produção e transação. A ineficiência coordenativa pode levar à deterioração prematura dos produtos, reduzindo a qualidade dos produtos transacionados. Trata-se de um fator de diferenciação de produto, influenciando o valor e capacidade de venda do bem. A perecibilidade dos produtos transacionados aumenta a importância do sistema logístico no interior da cadeia produtiva.

A variabilidade dos produtos quanto à quantidade e à qualidade é uma segunda característica genérica dos FLV. Os aspectos climáticos e a suscetibilidade a pragas e doenças são fatores que afetam diretamente a quantidade ofertada dos produtos (Mezzomo, 1997). A falta de um sistema de 
padronização eficaz em conjunção com a péssima infra-estrutura logística, como à presente no Brasil, são responsáveis pela grande variação na qualidade dos FLV.

A terceira característica refere-se a baixa relação valor-peso, que torna a localização geográfica uma variável de grande importância uma vez que influenciam o custo de transporte do produto.

Por último, a sazonalidade da produção, outra forma de especificidade temporal, permite a criação de quase-monopólios temporários nas regiões de produção específicas quando associada à especificidade locacional (OECD, 1997:11).

\subsubsection{DESCRIÇÃO DAS TRANSAÇÕES ENVOLVENDO FLV}

As transações envolvendo FLV apresentam uma série de problemas coordenativos derivados da dificuldade de monitoramento e previsão da produção, que constituem características inerentes a qualquer produção agrícola. A figura 4 identifica quatro tipos de transações no interior da cadeia produtiva de FLV, que constituem objeto de análise da tese.

FIGURA 4: DESCRIÇÃO DAS TRANSAÇÕES

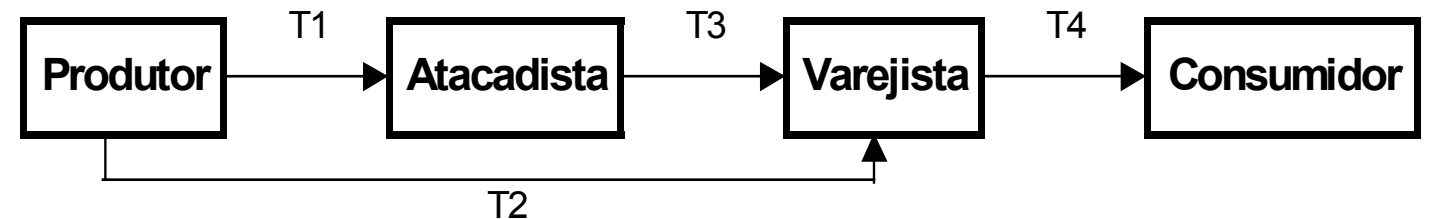

Fonte: Elaboração do autor

A transação $\mathrm{T} 1$ refere-se a compras efetuadas pelo atacadista junto ao produtor rural. Trata-se da forma predominante de comercialização utilizada pelo produtor. A transação T2, envolvendo produtor e varejista, passou a ter um papel de destaque recentemente com o crescimento da participação do varejo moderno no setor de FLV. A transação T3 refere-se à relação comercial entre atacadista e 
varejista. Por último, a transação T4 envolve a venda dos FLV do varejista para o consumidor final. $O$ foco principal do trabalho refere-se às relações envolvendo o setor varejista e, especificamente, o varejo moderno (supermercados, hipermercados e lojas de desconto).

O elevado grau de incerteza, endógena e exógena, e alta especificidade de ativo caracterizam tais transações quando a estratégia adota pelos agentes da cadeia baseia-se na oferta de produtos com qualidade superior.

A incerteza exógena é proveniente da dificuldade de previsão de situações que necessitem de coordenação, surgindo essencialmente de restrições na demanda e na produção agrícola. O primeiro tipo refere-se à dificuldade de prever a preferência do consumidor, que é extremamente diferenciada e diversificada, variando de acordo com a cultura e os hábitos alimentares de uma região. A dificuldade de mensuração e observação dos atributos físicos de frutas, legumes e verduras impede o consumidor de utilizar critérios objetivos para discriminar entre produtos, desenvolvendo preferências específicas, baseadas na experiência própria, que é extremamente variável e aleatória (Brousseau e Codron, 2000). O segundo aspecto surge da dificuldade de controlar as características dos produtos, o volume e o período de colheita e transporte. A complexidade do controle, tanto das características inerentes ao produto durante a produção quanto das condições de manuseio, transporte e armazenamento anterior à aquisição do produto pelo consumidor final, aumentam o grau de incerteza das transações entre os operadores da cadeia. Em suma, a coordenação eficiente entre compradores e vendedores é difícil de ser alcançada.

Já a incerteza endógena está diretamente conectada à dificuldade de avaliar as características do produto. Os problemas de mensuração ${ }^{13}$ dos atributos dos produtos frescos permitem a transferência de renda entre os agentes da cadeia. Brousseau e Codron (1997) argumentam que a carência de indicadores precisos sobre a qualidade dos FLV, decorrente da falta de informação técnica e científica a respeito de atributos mensuráveis (peso, tamanho, cor, etc.), não permite ao consumidor visualizar facilmente os atributos desejados no produto 
(aspectos nutricionais, sabor, maturação, etc.). Além disso, a alta velocidade de deterioração dos produtos torna a mensuração problemática no caso dos FLV. Em geral, os indicadores representam uma medida realizada em um período anterior à compra final pelo consumidor, tendo, assim, capacidade informativa limitada no momento da transação. A implementação de indicadores confiáveis apresenta custo elevado à medida que exige mão-de-obra especializada e monitoramento ao longo dos diferentes estágios de distribuição. Conseqüentemente, os agentes agrupam as transações em lotes de venda com alto grau de heterogeneidade, o que contribui para elevar a incerteza endógena.

Por último, Brousseau e Codron (2000) acrescentam que a incerteza das transações torna-se mais problemática em produtos com alta especificidade de ativos. Observam-se principalmente três categorias de especificidade nas transações envolvendo FLV: temporal, capital humano e marca. A primeira categoria, a especificidade temporal relacionada à facilidade de deterioração, não permite que as características dos produtos mantenham-se em um nível constante ao longo do tempo.

A segunda especificidade, capital humano, desenvolve-se em resposta à necessidade de conhecimento idiossincrático a respeito do gerenciamento da qualidade e da experiência adquirida no negócio. O aumento da freqüência da transação permite o aprendizado coletivo acerca da maneira como melhorar a efetividade da coordenação (Brousseau e Codron,2000). O aprendizado mútuo é um ativo de difícil reemprego.

A última categoria, a especificidade de marca, refere-se aos elevados investimentos realizados pelos agentes em recursos humanos e equipamentos para construir e consolidar uma imagem de fornecedor de produtos de qualidade superior. Por exemplo, as cadeias de supermercados criam uma marca baseada na reputação por vender produtos de alta qualidade, que pode ser rapidamente destruída pelo comportamento oportunista de seus fornecedores, colocando em risco os investimentos realizados na construção da imagem.

\footnotetext{
${ }^{13}$ Williamson (1985) e North (1990) descrevem problemas de mensuração como aqueles ocasionados pela dificuldade de medir qualitativamente e quantitativamente as características inerentes aos produtos.
} 
Outra questão importante das transações envolvendo produtos frescos trata-se da existência de informação assimétrica entre os operadores da cadeia, que permite a ocorrência de ação oportunista pela parte mais bem informada no momento da transação. Freqüentemente, o vendedor tem maior conhecimento sobre a qualidade do produto a ser comercializado do que o comprador, que geralmente só consegue avaliar a qualidade do produto após efetuar a compra, uma vez que é difícil identificar imediatamente e com segurança o nível de qualidade do produto adquirido. Conseqüentemente, o vendedor encontra-se em uma posição vantajosa em relação ao comprador durante o processo de negociação, especialmente em situações com carência de padrões bem definidos e instabilidade de preços.

Em suma, as transações ao longo da cadeia de FLV apresentam alto grau de incerteza, informação assimétrica e são extremamente específicas. A estratégia mais adequada é a adoção de medidas que visem amenizar tais problemas, visto que sua eliminação completa envolve custos extremamente elevados, tornando a tarefa impraticável.

Procurando reduzir os problemas transacionais desde o processo de produção até o instante de comercialização ao consumidor final, os operadores da cadeia produtiva vêm buscando novas formas de cooperação vertical. A cooperação vertical, que inclui tanto integração vertical quanto coordenação vertical, surge como um mecanismo de defesa dos operadores frente às mudanças no poder de mercado, contudo, geralmente, provoca mais desequilíbrios no futuro, gerando um ambiente altamente dinâmico.

\subsubsection{ATRIBUTOS DAS TRANSAÇÕES}

A análise dos atributos das transações deve considerar os agentes de ambos os lados da transação (Loader, 1996). O quadro 3 sintetiza os atributos dos quatro tipos de transação em foco no presente estudo para o caso específico de frutas frescas. As transações envolvendo legumes e verduras frescos apresentam 
os atributos incerteza e especificidade de ativos semelhantes, diferindo quanto ao atributo freqüência, que será maior para o produtor.

QUADRO 3: ATRIBUTOS DAS TRANSAÇOES

\begin{tabular}{|c|c|c|c|c|c|}
\hline \multirow[b]{2}{*}{ Transação } & \multirow[b]{2}{*}{ Agente } & \multicolumn{3}{|c|}{ Atributos da Transação } & \multirow{2}{*}{$\begin{array}{c}\text { Estrutura } \\
\text { de } \\
\text { Governança }\end{array}$} \\
\hline & & $\begin{array}{c}\text { Especificidade de } \\
\text { Ativos }\end{array}$ & Freqüência & Incerteza & \\
\hline \multirow{2}{*}{ T1 } & Produtor & $\begin{array}{ll}\text { Capital Humano } & \uparrow \\
\text { Ativo Físico } & \rightarrow \\
\text { Temporal }\end{array}$ & $\begin{array}{c}1 \text { vez por } \\
\text { ano }\end{array}$ & $\begin{array}{l}\text { Preço } \\
\text { Quantidade } \\
\text { Variedade }\end{array}$ & \multirow{2}{*}{$\begin{array}{l}\text { Mercado } \\
\text { e } \\
\text { Híbrida }\end{array}$} \\
\hline & Atacadista & $\begin{array}{l}\text { Capital Humano } \\
\text { Ativo Físico }\end{array}$ & Diária & Qualidade & \\
\hline \multirow{2}{*}{ T2 } & Produtor & $\begin{array}{ll}\text { Capital Humano } & \uparrow \\
\text { Ativo Físico } \\
\text { Temporal }\end{array}$ & $\begin{array}{c}1 \text { vez por } \\
\text { ano }\end{array}$ & $\begin{array}{l}\text { Preço } \\
\text { Quantidade } \\
\text { Variedade }\end{array}$ & \multirow{2}{*}{ Híbrida } \\
\hline & Varejista & $\begin{array}{ll}\text { Capital Humano } & \rightarrow \\
\text { Temporal } & \rightarrow \\
\text { Locacional } & \rightarrow \\
\text { Marca } & \end{array}$ & Diária & $\begin{array}{l}\text { Qualidade } \\
\text { Quantidade }\end{array}$ & \\
\hline \multirow{2}{*}{ T3 } & Atacadista & $\begin{array}{ll}\text { Capital Humano } \\
\text { Ativo Físico } \\
\text { Temporal }\end{array}$ & Diária & $\begin{array}{l}\text { Interrupção da } \\
\text { compra }\end{array}$ & \multirow{2}{*}{$\begin{array}{l}\text { Mercado } \\
\text { e } \\
\text { Híbrida }\end{array}$} \\
\hline & Varejista & $\begin{array}{ll}\text { Capital Humano } & \mathbb{1} \\
\text { Temporal } & \text { 年 } \\
\text { Locacional } & \text { Marca }\end{array}$ & Diária & $\begin{array}{c}\text { Disponibilidade } \\
\text { Qualidade }\end{array}$ & \\
\hline \multirow{2}{*}{ T4 } & Varejista & $\begin{array}{ll}\text { Temporal } \\
\text { Locacional } \\
\text { Marca }\end{array}$ & Diária & $\begin{array}{l}\text { Interrupção da } \\
\text { compra }\end{array}$ & \multirow{2}{*}{ Mercado } \\
\hline & Consumidor & Capital Humano $\uparrow$ & Semanal & Qualidade & \\
\hline
\end{tabular}

Fonte: Elaboração do Autor

Legenda: Alta 个édia $\rightarrow$

Na transação T1, o atacadista apresenta dois tipos de especificidade de ativo: capital humano e ativo físico. O primeiro tipo refere-se ao conhecimento específico da atividade e à experiência adquirida no setor de FLV. O segundo tipo refere-se ao investimento realizado para adquirir uma permissão para utilizar um box nas centrais públicas de abastecimento, ou então, adquirir um local próprio 
para realização das transações. Sob a ótica do produtor, a transação apresenta especificidade de capital humano, ativo físico e temporal. A primeira especificidade refere-se à experiência de cultivo de FLV, que exige o conhecimento de práticas e conhecimentos técnicos específicos a cada produto. A especificidade de ativo físico é mediana, uma vez que o ciclo do produto não é elevado e o terreno pode ser empregado para outras culturas. Por último, a comercialização do produto precisa ser rápida devido ao rápido processo de deterioração. As transações realizam-se diariamente entre $\mathrm{o}$ atacadista e diferentes produtores, estando $\mathrm{O}$ primeiro sujeito a incerteza quanto à qualidade do produto e o segundo quanto ao preço, quantidade e variedade do produto.

$\mathrm{Na}$ transação $\mathrm{T} 2$, os atributos freqüência e especificidade de ativos do produtor não sofrem alterações. Porém, a intensidade do atributo incerteza se reduz, uma vez que o varejista especifica antecipadamente o preço, a quantidade e variedade do produto. Do ponto de vista do varejista, verifica-se a existência de especificidade de capital humano (conhecimento da atividade), temporal, locacional e marca. A alta perecibilidade dos FLV restringe o tempo de exposição do produto na prateleira, impondo limitação de tempo para a comercialização de produtos de alta qualidade e a localização adequada da loja influencia medianamente o resultado das vendas do produto. Por último, a marca representa a imagem que o varejista desfruta junto ao cliente, tratando-se de um investimento altamente específico. As transações ocorrem diariamente para o varejista, que está sujeito a incertezas quanto à qualidade e à quantidade.

$\mathrm{Na}$ transação T3, o atributo freqüência permanece o mesmo para o varejista. A especificidade temporal é mais elevada, uma vez que o fluxo do produto apresenta uma transação a mais. Verifica-se o aumento da incerteza associada à qualidade do produto e o aparecimento da incerteza ligada à disponibilidade do produto desejado pelo varejista. Sob a ótica do atacadista, a transação apresenta especificidade de ativos de capital humano, ativo físico e temporal. As duas primeiras formas são idênticas às encontradas na transação T1. A relevância da especificidade temporal é menor para o atacadista em razão do giro diário do produto. Entretanto, o atacadista defronta-se com a possibilidade de 
interrupção da compra pelo varejista, comprometendo seu desempenho imediato em razão da forte barreira à entrada no fornecimento aos supermercados.

Por último, a transação T4 envolve o consumidor final e o varejo moderno. $O$ varejista defronta-se com as mesmas especificidades descritas anteriormente, porém com o aumento da especificidade temporal em razão da diminuição do tempo disponível em prateleira. As transações são diárias com um elevado número de consumidores. A interrupção da compra pelo consumidor trata-se da principal incerteza do varejista. Do ponto de vista do consumidor, a relação apresenta especificidade de ativo de capital humano, já que o consumidor utiliza a experiência adquirida no passado para realizar as transações no presente. Em geral, as transações são realizadas semanalmente em virtude da alta perecibilidade dos produtos e da escassez de tempo do consumidor para realizar compras. A incerteza em relação a qualidade é extremamente elevada, em razão da dificuldade de mensuração das características desejadas no produto.

A estrutura de governança de mercado que regula as transações T1 e T3 envolve a comercialização de pequenos volumes de FLV de baixa qualidade em relações esporádicas. Em geral, destina-se ao abastecimento de equipamentos varejistas pouco exigentes quanto à qualidade do produto e à regularidade da disponibilidade.

As formas híbridas de governança ocorrem entre os agentes nas transações T1, T2 e T3, envolvendo produtos de qualidade superior. A necessidade de obtenção de maneira contínua de FLV de alta qualidade, visando atender principalmente às necessidades do varejo moderno, faz com que tanto produtores quanto atacadistas busquem novos arranjos contratuais que permitam reduzir a incerteza quanto à qualidade e à disponibilidade do produto. A presença de risco associado à perda de reputação surge como principal salvaguarda contra a quebra contratual associada a não entrega do produto ou à entrega de produto com qualidade inferior à estipulada.

A forma de mercado governa as transações T4, envolvendo contratos informais entre os parceiros. O consumidor final utiliza a experiência adquirida no passado a respeito da reputação do varejo moderno como proteção contra a 
incerteza endógena e exógena, oferecendo como incentivo para a continuidade da relação à regularidade das compras e o pagamento de preço prêmio pela qualidade e, como forma de penalização, a interrupção da compra e a divulgação em redes de comunicação de informações negativas sobre o parceiro.

\subsection{O NOVO PAPEL DO VAREJO MODERNO}

O acirramento da competição entre os equipamentos varejistas, os novos hábitos comportamentais dos consumidores e a adoção de novas estratégias comerciais vêm aumentando a participação do varejo moderno nas vendas de FLV (Farina e Machado, 2000). A estratégia consiste em conquistar novos clientes por meio da oferta de uma ampla variedade de produtos em um mesmo local, permitindo facilidade e conveniência ao consumidor (Bishop, 1994).

Ao mesmo tempo, a importância do departamento de FLV aumentou significativamente no interior da cadeia varejista moderna (McLaughin e Perosio,1994). Os hipermercados e supermercados se caracterizam por uma crescente importância na distribuição varejista de produtos hortifrutigranjeiros em todo o mundo.

A estratégia adotada, baseada na alta qualidade ${ }^{14}$ dos produtos vendidos, associa a credibilidade da loja junto aos consumidores, por vender produtos de boa qualidade, aos atributos dos produtos frescos que oferece, cujas características qualitativas não são facilmente perceptíveis. Bagnara (1996) constatou nos EUA que as características dos produtos interagem com as características da loja, afetando diretamente a percepção da qualidade pelo consumidor. Lima Filho (1999) obteve resultados semelhantes para o Brasil, mostrando que a qualidade dos produtos hortícolas constitui um atributo importante na avaliação do varejo moderno pelos consumidores. O setor de FLV gera grande interesse de investimentos pelas redes pelo fato de atraírem

\footnotetext{
${ }^{14}$ Uma explicação mais detalhada do conceito de qualidade encontra-se na seção 4.3 .1 do próximo capítulo.
} 
consumidores com uma freqüência maior que a habitual, oferecendo comodidade e diversos serviços aos clientes.

Ao ser mais exigente que o setor varejista tradicional em termos de qualidade, grau de maturidade, data de entrega e embalagem dos produtos, o varejo moderno transmite credibilidade a respeito da qualidade dos produtos frescos oferecidos ao consumidor nas lojas, conquistando os clientes insatisfeitos com produtos vendidos em outros equipamentos varejistas e, conseqüentemente, provocando um progressivo aumento de sua participação na comercialização de FLV.

O varejo moderno tem enfrentado enormes dificuldades para alcançar suas metas de desempenho, uma vez que a estratégia de alta qualidade é muito sensível quanto à quantidade, qualidade e regularidade dos preços. Conseguir o suprimento regular e de alta qualidade de produtos frescos tem sido uma atividade de difícil realização pelo varejo moderno em razão do alto grau de incerteza das transações envolvendo FLV.

Um segundo tipo de estratégia adotada pelo varejo moderno baseia-se no preço. Oferecer o produto ao menor preço possível passa a ser o principal objetivo do fornecedor, não havendo preocupações quanto a qualidade do produto vendido e a regularidade de disponibilidade. As duas estratégias principais adotadas para o suprimento de diferentes lojas e/ou consumidores, preços baixos e alta qualidade, demandam estruturas de governança diferentes, quando os atributos de transação são afetados (Zylbersztajn e Farina, 1998). A adoção simultânea das estratégias trata-se de uma maneira do varejo moderno conseguir discriminar os preços dos produtos oferecidos.

Em geral, a alta especificidade de ativos encoraja a integração por permitir prevenir o comportamento oportunista. Segundo Azevedo (1996) a integração vertical parcial serve como instrumento de barganha em estruturas de governança em que a quase-renda deve ser negociada entre as partes. Ao mesmo tempo, a produção coordenada pela hierarquia favorece o intercâmbio de informação, facilitando a descrição dos produtos. A integração vertical parcial permite a 
aquisição de informação sobre o estágio produtivo subseqüente, sendo um instrumento de apoio para a negociação entre as partes (Riordan, 1990).

Entretanto, as formas organizacionais de mercado e híbrida predominam na coordenação das transações entre os agentes da cadeia de FLV. A coordenação escolhida pelo varejo moderno pode ser obtida pelo sistema de preços, quando o produto transacionado tem baixa especificidade de ativo e ofertado por vários agentes. Caso contrário, a coordenação eficiente pode exigir a elaboração de contratos onde ficam pré-definidos instrumentos de incentivo e controle da transação.

\subsubsection{GOVERNANÇA DE MERCADO}

A governança de mercado predominou hegemonicamente como mecanismo de coordenação na cadeia produtiva de FLV durante um longo período. Caracteriza-se pela ausência de compromissos de longo prazo, presença de contratos completos e papel preponderante do mecanismo de preços. Trata-se da forma mais adequada para sustentar a estratégia de preços baixos.

A coordenação de um sistema descentralizado requer que os agentes econômicos conheçam o local de comercialização e o preço do produto transacionado para que ocorra o funcionamento eficiente da estrutura. A capacidade de fornecer um local específico para a realização de transações anônimas entre compradores e vendedores constitui a principal vantagem do mercado físico. Apesar de ter sido a forma mais adequada no passado para coordenar as transações envolvendo FLV, os mercados físicos geravam elevados custos de transação em razão de:

(1) Crescimento do custo de avaliação (classificação e qualidade) em razão do elevado número de lotes;

(2) A exibição física do produto aumenta o tempo de distribuição e diminui o tempo de vida útil na prateleira; 
(3) O tamanho pequeno dos lotes e a grande heterogeneidade dos FLV dificultam a construção de lotes homogêneos e grandes, aumentando o custo de montagem.

Entretanto, a forma de mercado fornece ao varejo moderno informação a respeito do comportamento dos preços dos produtos comercializados, em razão da informação ser pública nesta situação. Tal fato reduz o risco de existência de um elevado diferencial de preços entre os concorrentes. Por outro lado, a governança de mercado não assegura o nível de qualidade e o volume do produto, que depende da disponibilidade dos fornecedores no momento da aquisição. Assim, apesar de apresentar custos de transação mais elevados, a existência da governança de mercado ainda tem um papel informativo importante para as transações entre os agentes da cadeia.

\subsubsection{A EVOLUÇÃO PARA MERCADOS VIRTUAIS}

A natureza da governança de mercado modificou-se, evoluindo dos mercados físicos para os mercados virtuais. As transações realizam-se a distância, baseadas no preço e em sistemas de classificação e padronização que deve ser adotado ao longo de toda a cadeia produtiva (Brousseau e Codron, 1997).

Os mercados virtuais possuem praticamente as mesmas propriedades dos mercados físicos, sendo eficientes no ajuste entre oferta e demanda, e apresentando elevada variação nos preços. Entretanto, não são eficientes para promover a qualidade e estimular a quantidade de investimento requerido em razão da dificuldade de avaliar corretamente as características dos produtos.

Sob o ponto de vista do comprador, o mercado virtual tem um custo inferior, pois permite a transferência de parte do custo de conferência das características dos produtos para os agentes localizados acima na cadeia produtiva. Entretanto, como o vendedor não se encontra presente no instante da checagem do produto, o surgimento de comportamento de risco moral por parte do comprador pode 
ocorrer. Quanto mais perecível o produto, maior a dificuldade de rápida renegociação e, portanto, maior a chance do surgimento de oportunismo ex-post.

Diferentemente dos mercados físicos, o preço do produto tornou-se privado, não sendo mais conhecido publicamente. Ao mesmo tempo, o crescimento dos contratos recíprocos de longo prazo (híbrido) faz com o que o preço não reflita mais o ajuste entre a oferta e demanda.

Um aspecto central para o desenvolvimento do comércio eletrônico na cadeia de FLV é a existência de produtos padronizados. A ausência de padrões e classificações acarreta o aparecimento de custos associados ao comportamento de risco moral por parte dos agentes. Assim, se o sistema de padronização é ineficiente, o deslocamento dos produtos para as centrais de distribuição física se faz necessário, em virtude das negociações sobre o preço e quantidade exigirem a inspeção física do produto, dificultando a logística adequada de coleta, distribuição e armazenagem. Quanto maior a especificidade temporal do produto, maior a exposição ao oportunismo pós-contratual.

\subsubsection{GOVERNANÇA HÍBRIDA}

A forma organizacional de mercado tornou-se ineficiente para ajustar a demanda crescente do varejo moderno por produtos com alta especificidade de ativos. O surgimento de acordos recíprocos de longo prazo permite melhorar o desempenho de algumas dimensões da governança de mercado (Brousseau e Codron, 1997).

Os acordos de longo prazo permitem a resolução de diversos problemas enfrentados pelo varejo moderno, como a necessidade de regularidade e volume programado, a possibilidade de estabelecimento de uma estratégia de qualidade por meio da definição e controle de requerimentos específicos e a redução de atrasos logísticos em razão da melhora da coordenação e da redução dos controles. O contrato relacional (McNeil, 1974) consiste na forma contratual que mais se aproxima dos arranjos de longo prazo. 
Dentro de tal contexto, dois novos arranjos híbridos têm surgido para governar as transações do varejo moderno com atacadistas (T2) e produtores (T3) na cadeia produtiva de FLV. A primeira forma refere-se a contratos informais de fornecimento. Neste tipo de arranjo, o compromisso entre os agentes baseia-se principalmente na confiança mútua, não existindo qualquer tipo de documento formal como garantia da transação. Normalmente, em tais contratos a determinação do preço ocorre após a entrega do produto, sendo baseado nas condições vigentes no momento da transação. Apresentam mecanismos de adaptação cooperativos referentes ao preço e surgem em relações de longo prazo recorrentes. O efeito reputação associado aos sistemas de informação baseado em redes de comunicação desempenha o papel principal de salvaguarda de tais contratos.

A segunda forma refere-se a parceria na produção. Como descrito por Nassar e Botellho (1999), na parceria o atacadista/varejista fornece ao produtor os insumos necessários a produção, interferindo diretamente no processo produtivo, objetivando obter maior garantia de disponibilidade de produto de alta qualidade e maior lucro. Tal forma de governança exige a adoção de algum tipo de controle da produção por parte do atacadista/varejista, incorrendo em custos adicionais. Novamente, o efeito reputação associado aos sistemas de informação inibe o comportamento oportunista de ambas as partes.

A aceitação da dependência bilateral pelos parceiros comerciais ajuda a explicar a mudança da estrutura de governança de mercado para a forma híbrida de estrutura de governança baseada em acordos de reciprocidade de longo prazo (Ménard, 1996). A dependência surge, normalmente, da especificidade de ativo (Williamson, 1985), dificuldade de avaliação do desempenho (Spiller e Zelner, 1997) ou complexidade da transação (Masten, 1991).

Os acordos recíprocos de longo prazo resultam da combinação de mecanismos bilaterais e coletivos, permitindo que a forma híbrida forneça mais proteção aos investimentos requeridos para a construção de uma estratégia de qualidade e a melhoria da coordenação das transações. Mesmo assim, os grandes investimentos específicos requeridos para obter produtos de alta 
qualidade estão sujeitos ao risco de quebra contratual em razão da criação de dependência bilateral que incentiva o comportamento oportunista das partes.

Por outro lado, os acordos de longo prazo não apresentam flexibilidade em termos de preços, em razão da impossibilidade dos fornecedores garantirem o fornecimento dos produtos dentro do prazo especificado com alta qualidade sem terem garantias sobre o preço. Assim, a estipulação do preço ocorre antecipadamente, não estando sujeito a variações na oferta e na demanda.

Ao mesmo tempo em que a adoção dos acordos recíprocos de longo prazo permite ao varejo moderno garantir o suprimento de produtos frescos de alta qualidade com a regularidade necessária, apresentam também custos mais elevados por apresentarem estratégia de fornecimento complexas e operações logísticas mais elaboradas.

Em suma, a adoção da forma híbrida torna a operação mais custosa e com maiores riscos em razão da falta de flexibilidade dos preços (Brousseau e Codron, 2000) quando comparada com a forma de mercado. Por outro lado, a adoção de contratos de fornecimento ou alianças informais reduz os custos de organizar as transações hierarquicamente, sendo uma alternativa mais viável que a integração vertical. A combinação dos mecanismos bilaterais de retaliação (Axelrod,1984), aprendizado mútuo e coletivo e efeito reputação, que derivam da repetição da transação dentro de uma relação de longo prazo, sustentam os compromissos informais oriundos da dependência bilateral. A ação coletiva fornece o suporte necessário para a efetividade dos mecanismos.

\subsubsection{COMPLEMENTARIDADE DAS FORMAS ORGANIZACIONAIS}

Um dos principais aspectos da organização da cadeia produtiva de FLV trata-se da convivência de diferentes estruturas de governança para reger transações semelhantes. Apesar de antagônicas quanto aos objetivos estratégicos, as duas estruturas de governança que sustentam as transações em foco na cadeia de FLV apresentam alto grau de complementaridade. 
Observações empíricas ${ }^{15}$ revelam a existência de um mix contratual, ou seja, uma determinada transação utiliza diferentes estruturas de governança, que se combinam no papel de atenuar os custos de transação. Assim, os atores econômicos definem um portfólio de estruturas de governança para regular uma determinada transação.

Há diversos argumentos que justificam a convivência de estruturas de governança distintas regendo a mesma transação. O primeiro argumento utiliza a idéia de que uma relação unívoca entre configurações dos atributos das transações e as estruturas de governança mantêm-se, ou seja, a diversidade de contratos rege transações efetivamente diversas, que se distinguem em pelo menos um dos atributos (especificidade de ativos, incerteza ou freqüência). Em suma, as diversas relações entre os agentes da cadeia constituem transações distintas, com atributos distintos e, portanto, associadas a estruturas de governança distintas (Azevedo e Silva, 2001).

Um segundo argumento baseia-se nos limites cognitivos dos agentes para explicar a heterogeneidade contratual. Em razão do pressuposto de racionalidade limitada, a solução determinística não existe, uma vez que não é possível distinguir precisamente as transações para níveis próximos dos atributos e, conseqüentemente, identificar a melhor solução. Portanto, a heterogeneidade das estruturas de governança decorreria da incapacidade dos agentes escolherem a solução de fato mais eficiente na economia dos custos de transação.

Um terceiro argumento baseia-se na idéia da escolha de mix contratual transitório para reger transações que compartilham dos mesmos atributos ${ }^{16}$. A falta de confiança inicial entre os agentes incentiva o aparecimento de formas contratuais distintas. Com o passar do tempo, desenvolve-se reputação mútua entre os agentes a respeito do comportamento pós-contratual, reduzindo o problema derivado da assimetria informacional. A evolução da relação resulta ao final do processo em estruturas de governança puras.

\footnotetext{
${ }^{15}$ Farina e Machado (2000), Nassar e Botelho (1999) e Brousseau e Codron (1997).

${ }^{16}$ Modelo de Gallini e Lutz (1992) citado por Lafontaine \& Shaw (1999).
} 
O último argumento, baseado no trabalho de Carlton (1979) citado por Azevedo e Silva (2001),supõe a existência de um mix contratual estável. O argumento baseia-se na idéia de que as estruturas de governança podem estar sujeitas a riscos não correlacionados e, assim, uma composição de diferentes estruturas de governança (um mix contratual) reduz o risco da transação.

O problema do mix contratual revela que, além de concorrentes, estruturas de governança podem apresentar algum grau de complementaridade tanto no nível individual quanto no nível coletivo.

Sob o ponto de vista do varejo moderno, a escolha de uma única estratégia de abastecimento pode excluir um grande número de clientes. A escolha da estratégia de alta qualidade não permite aos supermercados oferecer preços competitivos, perdendo clientes com menor elasticidade preço em todos os departamentos da loja. Individualmente, cada rede de supermercado determina o peso desejado para cada estratégia. A adoção pelo varejo moderno de uma combinação das estratégias de alta qualidade e preços baixos torna-se mais adequada para a comercialização de FLV no setor. Assim, o consumidor final defronta-se simultaneamente com locais onde convivem produtos de qualidade superior, dispostos em gôndolas refrigeradas e em embalagens especiais, e com produtos de preços inferiores, dispostos sem grandes cuidados.

Ao mesmo tempo, a combinação das estratégias permite a utilização de propriedades de ambas às estruturas, uma vez que a forma de mercado ajuda a reduzir a incerteza quanto ao preço, enquanto que a forma híbrida ajuda a reduzir a incerteza quanto à qualidade dos produtos.

Por ultimo, o conhecimento de uma estrutura de governança ajuda no gerenciamento da outra. Assim, a forma de mercado fornece informações essenciais a respeito da oferta, demanda, qualidade média e disponibilidade de categorias de produtos. A existência de transações via mercado permite a avaliação dos custos adicionais para melhorar a qualidade dos produtos, permitindo ao varejo moderno negociar com os fornecedores o preço e a qualidade requerida no momento da realização dos contratos. Da mesma forma, a forma de mercado necessita de informação proveniente das redes de 
comunicação da forma híbrida para melhorar o seu desempenho (Brousseau e Codron, 2000).

\subsection{PROBLEMAS DE COORDENAÇÃO DA CADEIA DE FLV}

Como constatado por Dimitri (1999) e Barkema e Drabenstott (1996), em geral a estratégia baseada na coordenação sob contratos predomina nas transações envolvendo a atividade produtiva agrícola. A capacidade de coordenação vertical torna-se elemento constituinte da competitividade da cadeia produtiva. A coordenação permite aos agentes definir e viabilizar estratégias competitivas, reagir a mudanças no meio ambiente ou aproveitar oportunidades de lucro.

As características únicas que os FLV apresentam tornam sua comercialização altamente específica e segmentada, dificultando o ajuste entre oferta e demanda. Se, por um lado, a oferta é disseminada e especializada devido ao grande número de produtores geograficamente espalhados, a demanda é disseminada, mas diversificada, devido à heterogeneidade das preferências dos consumidores.

A cadeia produtiva de FLV caracteriza-se pela existência de produtos com diferentes níveis de qualidade e descrição complexa. A complexidade de descrição dos produtos refere-se à quantidade de informação necessária para especificar os atributos do produto com detalhes suficientes que permitam sua seleção pelo comprador.

A dificuldade em mensurar a qualidade do produto, fato que envolve a necessidade de mão-de-obra especializada ao longo de toda cadeia produtiva, torna o custo de monitoramento elevado, favorecendo o surgimento de assimetrias informacionais decorrentes do oportunismo dos agentes. Um sistema de coordenação eficiente não deve somente promover o equilíbrio das quantidades ofertada e demandada, mas também garantir que a qualidade desejada do produto seja produzida na cadeia produtiva. 
A comercialização de produtos frescos de alta qualidade exige que investimentos sejam feitos por todos os agentes envolvidos. A falta de investimento adequado por pelo menos um dos agentes compromete a qualidade final do produto, prejudicando todos os componentes da cadeia. Assim, o desempenho eficiente depende da ação ser bem coordenada ao longo da cadeia. Qualquer falha de coordenação pode reduzir o valor do produto, aumentar os custos e provocar perdas na produção (Brousseau e Codron, 1997:3). A falta de mecanismos que permitam rastrear a movimentação do produto dificulta a atribuição de responsabilidades pelos danos ocorridos no produto, transferindo, em geral, uma proporção indevida do risco aos produtores, por meio da redução do preço ou pela devolução das remessas.

A coordenação vertical consiste em uma maneira de enfrentar o comportamento oportunista que traz vantagem para todos os agentes da cadeia produtiva ao compartilhar o risco entre todos os agentes que participam do processo (OECD, 1997:11).

Normalmente, os problemas de coordenação ocorrem em diferentes pontos da cadeia produtiva, envolvendo diferentes agentes. Assim, na relação entre produtor e comprador (T1 e T2), os contratos são preponderantemente informais e a falta de monitoramento da qualidade do produto no momento da entrega pelo produtor permite o surgimento do comportamento de risco moral por parte do comprador. Ao mesmo tempo, o produtor possui mais informação a respeito da qualidade do produto despachado, permitindo o surgimento de problemas associados à seleção adversa. O efeito reputação fornece a salvaguarda necessária ao cumprimento dos contratos.

Já na relação entre vendedor e consumidor final (T4), os contratos são informais e o problema de oportunismo pré-contratual é predominante, visto que o consumidor não consegue avaliar corretamente a qualidade do produto que está adquirindo e o vendedor, na maioria dos casos, possui tal informação. A falha de mercado criada pela assimetria informacional pode gerar uma situação onde somente os produtos de qualidade inferior serão comercializados no mercado, gerando o problema de seleção adversa (Akerlof,1970). 


\subsection{A PADRONIZAÇÃO COMO MECANISMO DE COORDENAÇÃO}

A coordenação das decisões econômicas de produção, investimento e consumo necessita da existência de produtos padronizados e terminologias adequadas para descrevê-los. A padronização e sistemas de classificação constituem instrumentos fundamentais para a ampliação do mercado consumidor e para o aumento da transparência das transações envolvendo FLV.

$\mathrm{O}$ tratamento da cadeia produtiva de FLV como um conjunto de contratos formais e informais que procuram garantir a transmissão de informação, incentivos e controles em resposta as mudanças do ambiente competitivo e, ao mesmo tempo, viabilizar estratégias empresariais, permite abordar o problema de adoção e implementação de sistemas de classificação e padrões sob a ótica da ECT.

Padrões e classificações adequados fornecem uma linguagem comum aos agentes da cadeia, viabilizando, por meio da redução dos custos de transação, a utilização do sistema de preços para produtos não homogêneos (Farina et al., 1997). Entretanto, quando o sistema de classificação e padronização ainda encontra-se em uma etapa inicial e apresenta grandes dificuldades de implementação, tanto pública quanto privada, a coordenação eficiente da cadeia fica prejudicada.

A ineficiência de sistemas de informação e padronização torna necessária a presença física do produto no momento de efetivação da transação, impedindo a redução dos custos logísticos. O fim da necessidade de inspeção física do produto requer a existência de sistemas efetivos de classificação e padronização dos

produtos, sistemas eficientes de monitoramento e sistemas informatizados de acompanhamento de preços em várias praças.

A falta de padronização na cadeia de FLV não permite a coordenação eficiente dos agentes ao longo da cadeia produtiva, impedindo que os ganhos potenciais de eficiência ocorram, atrapalhando o crescimento do setor. A necessidade de definir e garantir as características dos bens finais estimula 0 desenvolvimento da coordenação vertical entre os diferentes operadores da 
cadeia, implicando no surgimento de subsistemas estritamente coordenados ${ }^{17}$ uma vez que o padrão de concorrência exige a adoção de estruturas de governança específicas. Trata-se tipicamente do problema de organização dos diferentes estágios de produção.

No próximo capítulo discutem-se questões relacionadas à padronização (conceito, gênese, funções e tipos), formas de fornecer credibilidade ao padrão, transmitir a informação contida neles e o papel da reputação.

${ }^{17}$ Zylbersztajn e Farina (1997) utilizam o conceito de subsistemas estritamente coordenados para designar conjuntos de firmas coordenadas verticalmente por meio de mecanismos contratuais. Cada segmento dos SAGs apresenta diversas firmas com diferentes estratégias e tecnologias, com diferentes arranjos contratuais coordenando os elos. 


\section{PADRONIZAÇÃO E SISTEMAS DE CLASSIFICAÇÃO}

A importância de sistemas de classificação e padronização na organização dos mercados agroalimentares aumentou significativamente em decorrência da redução das barreiras comerciais e do aumento da preocupação com questões associadas à qualidade dos alimentos.

Mudanças no ambiente institucional, tecnológico e competitivo vêm modificando e ampliando o conceito de padrões e classificações nos sistemas agroindustriais. Novas tecnologias de informação melhoraram o conhecimento a respeito das preferências do consumidor, permitindo o aumento da capacidade de acompanhar e monitorar a evolução do comportamento do consumidor pelos agentes sem perda de eficiência. Atributos relacionados à segurança dos alimentos, conteúdo nutricional e preservação ambiental foram incorporados ao conjunto de informações determinantes da escolha do consumidor, segmentando a demanda por produtos. O crescimento da quantidade de atributos relevantes exige um novo processo de coordenação entre os segmentos da cadeia produtiva, que seja mais complexo do que o baseado simplesmente no sistema de preços. Barkema e Drabenstott (1996) indicam a predominância de relações de longo prazo baseadas em contratos, em substituição ao sistema tradicional de preços.

Ao mesmo tempo, a abertura comercial e a liberação de preços no mercado mundial permitiram uma ampliação do leque de estratégias que conjugam políticas de preço e qualidade do produto, visando aproveitar as oportunidades geradas pela tecnologia da informação e pelo desenvolvimento do mercado consumidor, alterando os padrões de concorrência vigentes (Farina,1999). A estratégia de diferenciação pela qualidade e a incorporação de valor adicionado aos produtos alimentares tornaram-se uma tendência mundial.

Dentro do novo contexto competitivo, a implementação da padronização tem a capacidade de impactar positivamente a coordenação de cadeias produtivas, uma vez que diminui os custos transação ao melhorar o fluxo de informações entre os agentes, homogeneizar a linguagem e facilitar possíveis estratégias de segmentação. 
Ao facilitar a identificação das características dos bens comercializados, a padronização reduz a variabilidade da informação a respeito do produto. A uniformidade dos atributos permite a redução da incerteza associada à transação, reduzindo o custo de mensuração. Barzel (1982:36) argumenta que a capacidade de mensurar os atributos do produto está diretamente conectada à existência de padrões. Por exemplo, as redes de fast-food fornecem alimentos com qualidade padronizada, permitindo ao consumidor encontrar o mesmo produto em diferentes lojas da rede (Klein e Saft, 1985: 349). A informação adquirida sobre a refeição em um determinado estabelecimento da rede é automaticamente transmitida a todas as lojas pertencentes à cadeia de fast-food. Ao permitir o fornecimento de informação crível a respeito do produto, a padronização provoca uma redução na variância do nível de qualidade do bem.

A consolidação de padrões de qualidade demanda a capacidade de criar organizações (estruturas de governança) capazes de fornecer o suporte necessário às ações geradoras e controladoras dos padrões desejados, podendo exigir ações tanto públicas como privadas.

A crescente elevação da participação de sistemas privados de classificação e padronização em substituição aos antigos sistemas públicos trata-se de uma importante tendência observada nos sistemas agroalimentares (Farina e Machado, 2000). A falta do padrão público efetivo incentiva firmas e associações a criarem e impingirem padrões privados para comunicar qualidade, segurança e diferenciação do produto aos demais agentes da cadeia. A criação de padrões tornou-se uma questão mais associada a estratégias privadas do que a políticas públicas.

A alteração de regimes públicos para regimes privados tem importantes implicações para a organização e governança da cadeia produtiva. Particularmente, tais estratégias estão associadas a sistemas produtivos estritamente coordenados, requerendo que os agentes realizem elevados investimentos para implementá-los (Reardon e Farina,2001).

Assim, existe uma crescente preocupação a respeito de eventuais efeitos de exclusão sobre os diversos agentes em virtude da adoção de sistemas 
estritamente coordenados, uma vez que a realização de investimentos específicos elevados pode impedir a atuação de pequenas e médias empresas em determinado setor, em razão da capacidade limitada de investimento dos agentes.

Como salientado por Farina (1999), a adoção ou alteração de padrões exige que todos os agentes da cadeia produtiva promovam ajustes para se adequar às novas regras de produção e comercialização. Os ajustes requeridos implicam em custos adicionais (novos equipamentos, insumos e mão-de-obra especializada), que devem ser compensados para que a adoção dos padrões possa ser integralmente implementada. A forma de compensação pode envolver prêmios de preço ou reduções de custo no processo. Entretanto, nem sempre os benefícios são claramente percebidos, o que pode inibir a difusão dos padrões. De acordo com a remuneração dos agentes e o fluxo de produto ao longo do SAG, o monitoramento dos padrões pode ser mais ou menos custoso, podendo significar a não adoção efetiva do mesmo (Sousa et al., 2000).

Quando os custos de ajuste ocorrem no curto prazo e os benefícios surgem somente em longo prazo, a adoção da padronização pode fracassar em razão da falta de adesão dos agentes. A generalização da adesão tem papel fundamental para o surgimento de externalidades positivas de rede devido à implementação de padrões e classificações.

A colaboração de todas as partes envolvidas torna-se essencial à efetividade do padrão, podendo surgir por meio de um comportamento cooperativo de barganha ou mediante um comportamento não cooperativo entre as partes. Entretanto, a estratégia não cooperativa nem sempre apresenta um equilíbrio Pareto-ótimo, podendo ser superada pela estratégia cooperativa (Farina e Zylbersztajn, 1993).

Em suma, existe uma consolidação da tendência crescente de diferenciação dos produtos e da redução do papel coordenador do Estado nos sistemas agroalimentares. Novas relações contratuais, formais ou informais, ao longo dos sistemas produtivos vêm se difundindo e exigindo que a padronização adquira um novo papel. 
Inicialmente, o capítulo abordará a questão da padronização dos produtos alimentares, apresentando os principais conceitos, características e tipos. Uma segunda etapa envolve a descrição de duas formas de gênese do padrão, endógena ou exógena à cadeia produtiva. Por último, discute-se a utilização de mecanismos de credibilidade e sinalização do padrão adotado e o papel da reputação no processo.

\subsection{CONCEITO E DEFINIÇÕES}

Historicamente, o surgimento de padrões na agricultura ocorreu nos mercados de commodities como um padrão público que objetivava reduzir os custos de transação, aumentar a eficiência das relações de trocas e permitir a expansão do comércio. Classificação e padronização são faces distintas, mas relacionadas, de um mesmo processo.

A classificação supõe a existência de algum padrão, podendo servir de base para a elaboração de padrões. Refere-se ao processo no qual bens, idéias e pessoas, são distribuídos em diferentes categorias. Classificar significa determinar as características de um produto ou comportamento com base em padrões, ou qualificá-los tendo como objetivo a elaboração de padrões.

Por outro lado, a padronização representa uma forma particular de reunir, filtrar e acumular informação acerca de produtos, serviços e processos (Foray, 1994). Segundo David e Greenstein (1990), um padrão representa um conjunto de especificações técnicas que os agentes da cadeia produtiva podem adotar de forma voluntária, tácita ou formal, ou autoritária.

Padrões e classificações são parâmetros definidos que segregam produtos similares em categorias, descrevendo-os com uma terminologia consistente, que pode ser compreendida pelas partes envolvidas na transação. Compreendem um conjunto de especificações técnicas, terminologias, definições e princípios de classificação e rotulagem que incluem regras de mensuração estabelecidas por regulamento ou autoridade e um sistema de categorização baseado em atributos quantificáveis (Jones e Hill, 1994). 
Em suma, um produto padronizado possui um conjunto de especificações que definem algumas de suas características ou do seu processo de fabricação.

Como discutido por Farina (1999), as especificações devem possuir as seguintes funções básicas: referência, compatibilidade, base para a ampliação de economia de rede e base mínima para garantir um nível de eficiência social. As duas primeiras funções básicas permitem melhorar a transparência das transações de mercado, sendo redutoras de custos de transação e coordenação, enquanto as duas últimas referem-se à redução dos custos associados à produção.

Os padrões e classificações podem abranger produtos, serviços e processos, podendo ser categorizados em padrões privados, públicos, coletivos, nacionais, setoriais, gerais e específicos, de uso voluntário ou obrigatório, entre outros.

Como salientado por Farina e Reardon (2000), um complexo conjunto de variáveis irá determinar qual a forma mais adequada para cada processo produtivo, quem será o agente que estabelecerá e implementará o padrão e quais os efeitos gerais da adoção de padrões sobre o funcionamento do mercado. A seguir serão apresentadas as categorias mais relevantes.

A ausência de padrões efetivos cria a necessidade de inspeção física dos bens, gerando custos e limitando a capacidade de coordenação da cadeia produtiva. Por exemplo, a marca comercial, que constitui uma forma de sinalização da qualidade, só consegue fornecer uma indicação confiável do nível de qualidade do produto se estiver diretamente associada à padronização das características do bem vendido sob aquela marca.

\subsection{CATEGORIAS DE PADRONIZAÇÃO}

Importantes dicotomias e categorizações distinguem padrões entre público e privado (Farina, 1999); voluntário, quase voluntário e obrigatório (Caswell, Bredahl e Hooker, 1998); geral e específico (Farina, 1999); processo e produto 
(Farina e Reardon, 2000). É importante ressaltar que as dicotomias fornecem situações polares, sendo as formas intermediárias mais freqüentes.

\subsubsection{PADRÃO DE FATO E PADRÃO DE DIREITO}

A forma de adesão ao padrão permite distinguir entre padrão de fato e padrão de direito. Ambos os tipos buscam reduzir a assimetria informacional entre os agentes e incompatibilidades técnicas do processo produtivo (Machado, 2000:76).

Os padrões de fato podem não estar originalmente associados a qualquer interesse privado ou, então, posteriormente sustentados por qualquer instituição, mas encontram-se sob uma forma bem documentada de domínio público. Por outro lado, podem ser elaborados por entidades que criam incentivos para que outros agentes adotem um conjunto particular de especificações técnicas (Foray, 1994).

Os padrões de fato surgem a partir de uma cadeia de micro-decisões descentralizadas ou pela ação voluntária de um grande agente. Os outros agentes seguem a entidade capaz de produzir sozinha uma forte difusão de uma opção particular, apesar da liberdade de escolha de cada um (Farina,1999).

$O$ padrão de direito surge por meio de acordos estabelecidos entre os principais agentes econômicos. A implementação pode ocorrer a partir da definição de padrões estabelecidos e difundidos por organizações de padronização voluntária ou, então, podem ser promulgados por aparelhos legislativos ou estruturas administrativas tornando-se compulsórios (Farina, 1999).

\subsubsection{PADRÃO DE PRODUTO E PADRÃO DE PROCESSO}

Padrões e classificações podem dizer respeito ao produto e ao processo (Farina e Reardon, 2000). Padrões que definem as características do processo ou do produto desfrutam de maior valor informacional do que padrões que definem 
desempenho e serviços. Enquanto os primeiros podem impedir a inovação dos padrões de desempenho, os segundos podem penalizar agentes especializados que buscam adaptar as características de seus produtos (Farina, 1999).

O padrão de produto refere-se às características que se espera encontrar no produto em um determinado ponto da cadeia produtiva. Por exemplo, a quantidade máxima de resíduo químico permitido no momento da aquisição do produto pelo consumidor final (Reardon et al., 2001).

O padrão de processo preocupa-se com as características do processo de produção adotado pelos agentes ao longo da cadeia produtiva. O padrão de processo pode especificar o nível de desempenho da produção do produto ou, então, criar ou manter determinadas condições a respeito do ambiente, trabalhadores entre outros fatores. A Análise de Risco e Ponto de Controle Crítico (HACCP) trata-se de um importante exemplo de padrões de processo.

Dependendo da orientação adotada, imposição de padrões e classificações influencia diretamente o efeito pretendido na coordenação eficiente da cadeia produtiva.

\subsubsection{PADRÃO PÚBLICO E PADRÃO PRIVADO}

A visão tradicional da literatura sobre classificação e padronização de produtos alimentares sempre focalizou o tema como uma questão de domínio exclusivamente público. A padronização é normalmente vista como um bem público necessário à eliminação da falha de mercado causada pela presença de informação imperfeita e assimétrica no mercado.

Entretanto, há formas intermediárias onde o padrão não é totalmente público ou privado. Farina (1999) argumenta que o surgimento de situações intermediárias deve-se ao fato de existirem diferentes conceitos para a dicotomia entre público e privado. O primeiro conceito identificado na literatura por Farina (1999) envolve a determinação do agente dominante na implementação do padrão no ambiente institucional. A identificação do agente que preponderantemente promulga e monitora a adesão ao padrão consiste a preocupação central da 
diferenciação. Em tal situação, o agente principal pode ser o Governo, firmas privadas, associações representando firmas privadas ou entidades de classe.

Por outro lado, o bem público na Teoria Econômica é definido como um bem que deve ser fornecido na mesma quantidade para todos os consumidores afetados, sendo um tipo especial de externalidade de consumo (Varian, 1994:622). Dentro de tal linha, padrões e classificações são categorizados como bens públicos quando têm características de não-exclusão ou não-rivalidade, exibindo economias de rede ${ }^{18}$ (Farina, 1999). De modo geral, entende-se padrões e classificações na literatura como bens públicos oferecidos pelo governo, ou, como bens coletivos oferecidos por uma entidade independente profissional, ou, alternativamente, como bens privados, quando constituem base para sustentação de estratégias de firmas individuais.

Outro conceito envolve a questão de acessibilidade ao padrão. Tal classificação verifica se o benefício da adesão ao padrão é acessível a qualquer agente ou se existem barreiras à adesão que excluem alguns agentes. Codron et al. (2000) classificam o padrão segundo o critério de inclusão ou exclusão do agente ao benefício gerado pela padronização. Em tal situação, a dicotomia entre público e privado envolve a questão de se os agentes que conseguem prover os atributos exigidos terão livre acesso ao sinal de qualidade fornecido pelo padrão.

O quarto conceito discutido por Farina (1999) refere-se ao tipo de adesão exigido à adoção do padrão. Em tal abordagem, o padrão será de adesão obrigatória se todos os agentes devem aderir a ele; voluntária quando a adoção ocorre de forma espontânea; quase-voluntária se a adesão não for obrigatória mas é necessária para a firma permanecer competitiva. Um padrão público refere-se à situação de adesão obrigatória para todos os agentes envolvidos no processo produtivo. Por outro lado, o padrão privado ocorre quando a adesão for voluntária ou quase-voluntária.

\footnotetext{
${ }^{18}$ A existência de economias de rede ocorre quando os ganhos decorrentes do uso ou consumo do bem ou serviço são afetados positivamente pelo número de agentes que consomem ou utilizam o referido bem ou serviço. Assim, quanto maior o número de consumidores e produtores que usam determinado padrão, maior o ganho alcançado por usuários adicionais, dados os ganhos em comparabilidade e intercambialidade (Farina, 1999).
} 
O presente estudo alinha-se com o primeiro conceito, indicando como padrão público à situação que o principal órgão promulgador é o Estado.

\subsubsection{PADRÃO DE REFERÊNCIA: GERAL OU ESPECÍFICO}

Os padrões de referência incluem definições, especificações técnicas, terminologias e princípios de classificação e rotulagem a respeito do produto ou do método de produção codificado em um documento. Estabelecem e tornam público um certo conjunto de características que asseguram as propriedades de reprodução, equivalência e estabilidade dos produtos, adequadas às condições de produção e de troca (Foray, 1994).

A utilização do padrão de referência permite a rápida identificação do produto e dos atributos de qualidade e desempenho, facilitando a coordenação entre os agentes da cadeia ao reduzir os custos de aquisição da informação sobre os produtos pelos agentes e limitando as situações sujeitas ao comportamento oportunista de risco moral.

O estabelecimento de padrões de referência permite o pagamento de preço prêmio ou descontos para qualquer divergência em relação ao padrão estabelecido, além de permitir o surgimento de mercados virtuais que tornam a inspeção física do produto desnecessária.

A diferença entre padrão geral e específico baseia-se no papel do padrão na tentativa de aumentar a transparência e a competitividade. Farina (1999) entende que o padrão geral pode aumentar a transparência, reduzir barreiras à entrada e intensificar a competição de preços. Por outro lado, o padrão específico permite a diferenciação do bem, criando uma vantagem competitiva pelo estabelecimento de um produto único.

A adoção de padrões específicos diferenciados tem como objetivo a segmentação do mercado buscando a obtenção de vantagem competitiva e lucro adicional. A alteração dos atributos das transações em virtude da segmentação pela qualidade baseada na diferenciação vertical do produto conduz à adoção de 
estruturas de governança que sustentem a estratégia, criando-se um subsistema estritamente coordenado por uma empresa ou grupo de produtores.

\subsubsection{O ESTABELECIMENTO DE PADRÕES MÍNIMOS}

A complexidade e a universalidade tendem a evoluir em sentido contrário. Quanto mais simples for o padrão definido, em termos de atributos identificáveis e da classificação associada, maior será a adoção pelos agentes e, conseqüentemente, maior a economia de rede alcançada.

A implementação do padrão mínimo fornece um padrão de referência para que os agentes envolvidos nas transações possam avaliar o produto transacionado, permitindo tanto o pagamento de preços prêmios quanto os descontos decorrentes de divergências em relação ao padrão.

O padrão mínimo estabelece um determinado conjunto de características e especificações a respeito do produto (ou do processo produtivo) que devem ser totalmente atendidas para que a transação possa ocorrer. A informação criada por padrões mínimos facilita a coordenação ao longo da cadeia produtiva.

Como descrito por Leland (1979:1342), a imposição de padrões mínimos de qualidade reduz a oferta de produtos de baixa qualidade, sendo uma possível forma de remediar a falha de mercado gerada pela assimetria informacional e beneficiar os agentes envolvidos nas transações. O argumento de Leland é consistente com os resultados obtidos no estudo empírico realizado por Ferguson e Carman (1999) para o mercado de kiwi nos Estados Unidos e na Nova Zelândia. O estudo mostra que o consumidor utiliza a padronização para identificar as características desejadas na fruta, reduzindo a incerteza quanto à qualidade esperada do produto.

Quando existem restrições a serem atendidas na transação, a falta de padrões mínimos de referência pode levar à integração vertical ou a formas híbridas de governança que necessitam de sistemas de controle eficientes e custosos, atrapalhando a coordenação eficiente da cadeia produtiva. 
Por último, a impossibilidade dos agentes verificarem sozinhos a conformidade com padrões de referência torna necessária a presença de entidades independentes, privadas ou públicas, para informar os atributos específicos e desejados dos produtos.

\subsection{ASPECTOS GERAIS DA PADRONIZAÇÃO NA CADEIA DE FLV}

Visto que os produtos agrícolas apresentam um vasto conjunto de características como peso, tamanho, formato, densidade, cor, gosto, odor, limpeza, firmeza, maturidade, entre outros, a existência de um sistema que facilite a comunicação entre os agentes torna-se vital para eficiência coordenativa da cadeia.

Nos últimos anos, o sistema agroalimentar inicialmente transferiu o foco de atenção da qualidade do produto para a qualidade do processo e, mais recentemente, para o enfoque sistêmico, onde a necessidade de cooperação entre os agentes tem papel fundamental. $O$ conjunto de ações desempenhadas pelos agentes, monitoradas pelo Estado e ditadas pelas exigências de qualidade dos consumidores, é que vai garantir a qualidade dos produtos segundo um enfoque sistêmico. Kühl e Drescher (1996) indicam que o principal fator de modificação da demanda por alimentos consiste na elevação dos padrões mínimos de qualidade dos atributos desejados do produto. Quanto maior a qualidade exigida dos produtos produzidos, maior o incentivo à coordenação vertical, possibilitando um fluxo de informação mais eficiente e o aumento do controle de cada etapa do processo produtivo.

$\mathrm{Na}$ medida em que o processo produtivo se desenvolve, aumenta a complexidade dos produtos e o crescimento da divisão horizontal e vertical do trabalho multiplica os problemas de complementaridade e compatibilidade técnica entre os bens, aumentando a demanda pela adoção de padrões (Farina, 1999).

Segundo Giovannucci e Reardon (2001), a utilização de uma terminologia comum para reger as transações apresenta diversos benefícios. Primeiro, elimina a necessidade de presença física do produto no momento da aquisição, 
permitindo a utilização de mercados virtuais. Segundo, melhora os incentivos por qualidade e segurança. Terceiro, torna a informação a respeito do produto mais confiável. Quarto, facilita a comparação de preço e qualidade. Quinto, reduz os riscos associados ao comportamento oportunista. Sexto, diminui os mecanismos de controle das transações. E, finalmente, facilita a resolução de disputas a respeito da qualidade dos produtos.

Assim, o estabelecimento de padrões, resultante do desenvolvimento do sistema produtivo, tem como objetivo construir um instrumento eficaz que permita a adoção de medidas cada vez mais precisas e procedimentos de controle da qualidade mais confiáveis. Ao mesmo tempo, fornece um impulso adicional ao desenvolvimento da qualidade ao permitir que o sistema de preços diferencie os níveis de qualidade.

\subsubsection{PADRÃO DE QUALIDADE}

Um bem pode ser descrito como uma cesta de um conjunto de diferentes características que cada indivíduo ordena conforme suas preferências pessoais (Tirole, 1988:99). Desde os trabalhos de Theil (1952), Houthakker (1952) e Lancaster (1966) considera-se a qualidade de um bem como uma composição de propriedades que podem ser refletidas no sistema de preços. Assim, a característica qualidade influencia diretamente a escolha ótima do indivíduo, variando conforme o gosto individual de cada um.

O conceito qualidade do produto refere-se ao conjunto de propriedades e características que têm a capacidade de satisfazer necessidades e desejos dos indivíduos (Batalha, 1997). A escolha dos atributos de qualidade relevantes na determinação do preço do produto depende da capacidade cognitiva do indivíduo em reconhecer a presença do atributo no bem.

A padronização diz respeito a várias características do produto como qualidade (aparência, gosto, limpeza), segurança (controle da quantidade de resíduos), autenticidade (garantia do local geográfico de origem ou uso de um determinado processo) e excelência do processo produtivo (contaminação 
ambiental e ambiente de trabalho saudável). Segundo Reardon et al. (2001) vem ocorrendo um constante crescimento das exigências por um mix de características do padrão, principalmente na implementação de padrões privados.

O processo de padronização dos FLV consiste em uma tarefa de difícil realização, em razão da dificuldade de medição objetiva da qualidade dos produtos. Qualquer transação envolvendo FLV caracteriza-se por problemas de incerteza a respeito da qualidade dos bens e assimetria de informação entre os agentes. A adoção de tipologias adequadas que agrupem uma diversidade de atributos dos produtos torna-se necessária.

Uma tipologia desenvolvida por Nelson (1970) classificou bens e serviços conforme os atributos que o indivíduo consegue avaliar no instante da compra. A classificação diferencia os produtos em bens de pesquisa (search goods), bens de experiência (experience goods) e bens de crença (credence goods), dependendo do atributo preponderante do bem.

O primeiro grupo inclui os atributos percebidos imediatamente pelo indivíduo, como o preço e características relacionadas à qualidade externa do produto (tamanho, cor, textura, manchas, etc.). No segundo grupo encontram-se os atributos que só podem ser avaliados pelo consumidor após a compra (sabor, frescor, amadurecimento). Por último, os atributos de crença referem-se a características não detectáveis mesmo após o consumo, como a ausência de resíduos químicos e pesticidas, questões ambientais, religiosas e geográficas, entre outras. Outra forma de interpretação da tipologia de Nelson (1970) baseia-se na dificuldade e no custo com que o indivíduo se defronta ao tentar avaliar a qualidade dos bens e serviços no instante da compra.

Tradicionalmente, na literatura econômica, os produtos alimentares são classificados como bens de experiência, embora a crescente preocupação dos indivíduos com as características nutricionais e a segurança dos alimentos atualmente tenha provocado um aumento no número de atributos de crença desejados pelo consumidor (Codron et al., 2000:1). Kühl e Drescher (1996) concluem que o número de atributos de crença considerados pelo consumidor 
tende a expandir-se continuamente no sistema agroalimentar, em virtude do desenvolvimento de técnicas de controle mais efetivas.

Spers (2000: 302) apresenta outra tipologia que classifica os atributos de qualidade avaliados pelo consumidor na escolha do alimento em intrínsecos e extrínsecos. A qualidade intrínseca inclui atributos que necessitam utilizar instrumentos (selos, certificados, marcas e rotulagens) para serem observados pelo consumidor, estando a percepção fortemente associada ao grau de confiança dos instrumentos utilizados. A ausência de vestígios de resíduos químicos e conservantes, o valor nutritivo, a reputação do produto ou empresa e as questões ambientais representam exemplos de atributos intrínsecos. Já a qualidade extrínseca inclui atributos de fácil percepção externa pelo consumidor, como preço, cor, aparência, tamanho e formato. Em geral, a percepção e visualização dos atributos de qualidade dos FLV não ocorrem facilmente, sendo, portanto, atributos intrínsecos.

Em geral, problemas de assimetria de informações e de incerteza sobre a qualidade dos bens caracterizam a maioria das transações envolvendo FLV. A utilização de garantias sobre a qualidade do produto elimina completamente o problema informacional, mas favorece o surgimento dos problemas de risco moral e seleção adversa.

Quando a descrição de qualidade envolve muitos atributos, o fornecimento de garantias torna-se muito complexo para ser avaliado pelo indivíduo, sendo necessário incorrer em custos elevados para providenciar instrumentos informativos eficientes. A adoção de um padrão de referência baseado na qualidade constitui uma forma de adicionar informação a respeito de determinadas especificações do bem transacionado sem elevar substancialmente os custos e, ao mesmo tempo, permitir a cobrança de preço prêmio por produtos com qualidade acima da referência.

Somente a criação de estruturas de governança, públicas ou privadas, capazes de garantir o monitoramento dos padrões desejados permitirá a consolidação de padrões de qualidade na cadeia de FLV. 


\subsubsection{GÊNESE DA PADRONIZAÇÃO NA CADEIA DE FLV}

Existem alguns princípios básicos a serem seguidos no estabelecimento de um sistema de classificação e padronização. Segundo Giovannucci e Reardon (2001), o primeiro passo consiste na identificação dos principais agentes afetados, visando determinar sobre quem incidirá a mudança institucional. Visto que o processo de implementação e desenvolvimento de padrões pode ser longo e árduo, a solidificação de compromissos com as partes envolvidas torna-se de vital importância para a efetividade do processo.

Um segundo fator que deve ser considerado na fase inicial do processo consiste na identificação precisa dos propósitos da implementação de padrões e classificações. Nem sempre o tipo de padronização adotado favorece de forma igualitária e efetiva todos os agentes envolvidos.

A análise da padronização de produto deve considerar a predisposição dos agentes na adoção do novo padrão proposto. Os participantes da cadeia produtiva devem identificar as vantagens da adesão aos padrões, de modo a ser incentivados a realizar os investimentos necessários para o enquadramento nos padrões.

Assim, todos os participantes devem conjuntamente avaliar o sistema atual, decidir o agente (interno ou externo à cadeia) responsável pela promulgação e controle dos padrões adotados, prever os efeitos coordenativos e determinar os impactos distributivos, permitindo que o processo de padronização e classificação seja transparente (Giovannucci e Reardon, 2001).

Farina (1999) cita três razões que dificultam a introdução de padrões em uma cadeia produtiva. Em primeiro lugar, a padronização requer um elevado investimento em capital físico, financeiro e humano. Em segundo lugar, cada firma ou consumidor espera que outro agente adote o padrão primeiro, permitindo uma avaliação mais precisa dos custos e benefícios associados à adoção, reduzindo a margem de risco do investimento. Tal fato inibe a implementação ou a mudança do padrão (Kindleberger, 1983:388). Por último, os efeitos redistributivos gerados na coletividade nem sempre são desejados por todos. 
O padrão pode ser imposto pelo Estado, caracterizando a influência do ambiente institucional sobre o SAG, ou ser estabelecido a partir de iniciativas de agentes com interesses específicos, em uma forma de coordenação que, por exemplo, poderá ser executada por associações e/ou cooperativas.

\subsubsection{O SURGIMENTO EXÓGENO DO PADRÃO}

O surgimento exógeno refere-se à situação em que agentes externos à cadeia produtiva determinam 0 formato do padrão. Em tal situação, a padronização pode ser imposta pelo Estado, associações profissionais autônomas ou firmas dominantes de outro segmento produtivo. De modo geral, entende-se a padronização como um bem público quando oferecido pelo Estado, como um bem coletivo quando oferecido por uma associação profissional autônoma, ou como um bem privado quando sustenta estratégias individuais (Farina, 1999).

Mercados fragmentados apresentam grandes dificuldades na adoção de padrões por todos os agentes, limitando os benefícios ao subgrupo de produtores que voluntariamente participam do sistema. A intervenção pública pode ser necessária para que se inicie o processo de padronização.

Em geral, as razões que levam à interferência do Estado estão ligadas à característica de assimetria informacional no mercado de alimentos, que cria uma situação de falha de operação no sistema de preços. Mesmo com a possibilidade do surgimento do efeito reputação, a existência de empresas que operem com produtos de baixo valor e com grande freqüência de transações, conduz à necessidade do estabelecimento de controles (Zylbersztajn, 1999).

North (1990) entende o papel do Estado como provedor de um ambiente promotor, e não inibidor, da atividade produtiva. O Estado define o ambiente institucional como o resultado da ação da sociedade, tendo papel de redutor dos custos de transação ao garantir os direitos de propriedade e fornecer um ambiente necessário para os agentes privados atuarem.

Segundo North (1990), as instituições são vistas como as regras, os costumes ou os limites legais para a ação dos indivíduos, enquanto as 
organizações são construídas pelos agentes visando explorar os incentivos presentes na sociedade.

De acordo com Farina e Zylbersztajn (1994), o Estado possui um papel importante na determinação do ambiente institucional vigente, coordenando disputas e organizando a atividade de produção, por meio do estabelecimento de padrões, políticas de preços, transmissões de informações relevantes e outros mecanismos. A presença do Estado na criação de sistemas de classificação e padronização baseia-se na criação de um ambiente institucional formado por leis, normas e decretos que regulamentem a atuação dos agentes no interior dos diversos SAGs.

As normas são um mecanismo poderoso para regular conflitos entre grupos de dois ou mais indivíduos sem a existência de uma autoridade central. $\mathrm{Na}$ política, no direito e na liberdade civil, as normas informais sobre o que é um comportamento aceitável são mais fortes e conhecidas do que o sistema legal formal. Os trabalhos desenvolvidos por Furubotn e Pejovich (1974) e Schotter (1981) demonstram que uma grande quantidade de comportamentos individual baseia-se em padrões que não podem ser determinados somente por um indivíduo. Se o comportamento coordenado ocorre sem a intervenção de uma autoridade central que o policie, a regulação resultante do conflito é decorrente da existência de normas.

Ao estabelecer padrões, o Estado deve considerar os custos de implementação, uma vez que o provimento de qualidade requer investimentos elevados e a sociedade nem sempre apresenta condições de suportar os preços resultantes. Em geral, os padrões observados em países desenvolvidos de alta renda são impraticáveis em países menos desenvolvidos.

De maneira similar, a atuação de associações profissionais autônomas consiste na definição e implementação de padrões coletivos com o amparo do Estado, visando proteger os consumidores contra a adulteração e limitar a concorrência (Farina, 1999). De forma limitada, as associações podem excluir membros, ou tornar público o comportamento oportunista de empresas, entretanto, cabe ao Estado o exercício do poder de coerção, que é a forma mais 
forte de motivação do cumprimento de determinações legais. Não há substituto para o Estado na preservação das regras ditadas pela sociedade (Zylbersztajn, 1999).

\subsubsection{O SURGIMENTO ENDÓGENO DO PADRÃO}

O surgimento endógeno refere-se à situação em que agentes internos à cadeia produtiva determinam o formato do padrão. Segundo Farina e Machado (2000), o padrão público não conseguir evoluir no mesmo ritmo que as mudanças nas preferências dos indivíduos em razão da falta de incentivos adequados aos agentes econômicos para sua adoção e a pequena capacidade de coerção do setor público frente ao não cumprimento das regras estabelecidas. Quando o Estado não consegue promover corretamente a padronização, outras formas surgem naturalmente no ambiente institucional para suprir tal deficiência.

A falta do padrão público incentiva firmas e associações a criarem e impingirem padrões privados, utilizando rótulos e sistemas de certificação próprios para comunicar aos agentes a qualidade, a segurança e a diferenciação do produto. A efetividade dos padrões privados está diretamente associada ao bom funcionamento do aparato jurídico de proteção ao consumidor e dos instrumentos de coerção que garantam o cumprimento dos contratos por todos os agentes envolvidos nas transações.

Por outro lado, a criação do padrão privado pode aumentar o poder de determinados grupos em mercados concentrados, perpetuando o domínio das empresas líderes. Quanto mais ampla for a dominação do mercado, maiores os efeitos alcançados dentro da estrutura produtiva na qual se insere a empresa. Em tal situação, a adesão de eventuais fornecedores ao padrão privado, exigido pela empresa dominante, ocorre de forma voluntária, se tratando unicamente de uma estratégia para conquistar novos clientes.

Em geral, os padrões associados a estratégias competitivas de empresas privadas apresentam maior complexidade e restrições, necessitando de 
monitoramento de todo processo ao longo da cadeia produtiva e o amparo de contratos formais e informais.

\subsubsection{COMPLEMENTARIDADE DOS PROCESSOS}

O fato dos sistemas agroindustriais estarem crescentemente utilizando relações contratuais entre os agentes torna mais complexa a determinação de responsabilidades por eventuais desalinhamentos entre as normas legais e as práticas observadas, passando a coexistir tanto a ação privada quanto a pública. Ao mesmo tempo, os consumidores, cada vez mais exigentes e valorizando atributos de qualidade, passam a pressionar o Estado por meio de entidades de representação, motivando a criação de organizações especializadas para lidar com a coordenação vertical dos SAGs, visando atingir determinados padrões de qualidade.

Como salientado por Zylbersztajn (1999:5), "a consolidação de padrões de qualidade demanda capacidade de criar organizações, estruturas de governança, que sejam capazes de dar o suporte necessário às ações geradoras e controladoras dos padrões desejados. Isto pode demandar ações tanto públicas como privadas". Na definição dos padrões a participação conjunta do Estado e das entidades privadas, individuais ou coletivas, deve ser incentivada para que um sistema formal se torne não efetivo rapidamente.

O fato do padrão público formal não conseguir evoluir tão rapidamente quanto as mudanças no ambiente institucional, em razão das dificuldades burocráticas e políticas inerentes ao processo, faz com que o padrão privado informal predomine nas transações entre os agentes da cadeia. Segundo North (1990), as instituições tendem a mudar lentamente, enquanto as organizações ajustam-se rapidamente ao ambiente institucional, nele interferindo em busca de vantagens competitivas. No processo de criação e substituição de instituições, o Estado sofre forte pressão, tanto para adequar sua estrutura interna administrativa de modo a dar agilidade à aplicação das leis, quanto de grupos de interesse presentes na sociedade. 
Para o exercício da coerção, e como parte do papel público, está o monitoramento dos agentes. Em geral, o monitoramento do cumprimento de normas legais é custoso, podendo, em alguns casos, ser exercido pelo setor privado, em coordenação com o setor público. Desta forma, as associações de defesa do consumidor monitoram a qualidade dos alimentos, tornando público ou denunciando ao poder público situações em desacordo com a lei.

Entretanto, o monitoramento da adesão a padrões públicos ou privados deve ser assumido em determinado momento pelo Estado, o único que realmente desfruta de poder mandatório sobre os agentes privados (Farina, 1999). O poder de coerção para fazer cumprir determinações legais torna-se fundamental ao processo de implementação de padrões. Assim, a efetividade dos padrões privados depende do bom funcionamento do sistema jurídico ou outras instituições que protejam os consumidores como, por exemplo, o PROCON no Brasil. Em geral, considera-se o sistema judiciário um bem público que dificilmente pode ser substituído pelo setor privado (Zylbersztajn, 1999).

\subsubsection{IMPACTOS DISTRIBUTIVOS DA ADOÇÃO DE PADRÕES}

A adoção de padrões envolve geralmente a mudança na qualidade do produto transacionado, como, por exemplo, alterações no número de atributos intrínsecos e extrínsecos valorizados pelo consumidor. A mudança nas regras de comercialização do produto, decorrente da introdução e/ou modificação do sistema de classificação e padronização, tem impactos distributivos importantes da cadeia produtiva, podendo ser considerada como uma forma de alteração do ambiente institucional.

Segundo North (1994), a mudança institucional consiste em um processo presente em todo lugar, contínuo e incremental, sendo conseqüência direta das escolhas individuais diárias dos agentes. A origem da mudança está diretamente associada à oportunidade de benefício percebida pelos agentes com a alteração do marco institucional, podendo ter uma origem externa ou interna ao sistema produtivo. 
Dois aspectos importantes e complementares dos sistemas de padronização e classificação devem ser considerados na análise dos impactos distributivos ao longo da cadeia de FLV. O primeiro aspecto refere-se às padronização de produto, que define atributos referentes à qualidade e às características desejáveis no bem transacionado. A padronização do produto modifica e melhora a disseminação de informação entre os agentes ao tornar homogênea a linguagem utilizada na transação. Também facilita a adoção de estratégias de segmentação ao criar padrões de referência para descrever as características do produto.

O segundo aspecto diz respeito à padronização de embalagem, estando associado diretamente ao fluxo de informações e a rastreabilidade ${ }^{19}$ do produto ao longo da cadeia (Souza et al., 2000). A redução das perdas em virtude do aumento da proteção contra a manipulação incorreta dos produtos promove ganhos evidentes de produtividade na comercialização de FLV. Por exemplo, a introdução de embalagens adequadas para o transporte rodoviário de mamão, em substituição ao método tradicional de empacotamento dos produtos em jornal e empilhamento diretamente sobre a carroceria do caminhão, reduziria o índice de perda dos atuais $40 \%$ para um valor bem inferior.

$O$ conceito de rastreabilidade refere-se à possibilidade de conhecimento do fluxo do produto ao longo do SAG e à habilidade de adequar-se aos procedimentos existentes nas diversas etapas. A melhoria do fluxo de informação ao longo do processo permite o controle e a verificação imediata do caminho percorrido pelo produto desde o produtor rural até o consumidor final.

As padronizações do produto e da embalagem permitem a redução das assimetrias informacionais, inibindo o comportamento oportunista dos agentes, permitindo a diminuição das salvaguardas contratuais e, conseqüentemente, reduzindo o custo de transação. O impacto na redução dos custos de transação relaciona-se diretamente à forma organizacional empregada para coordenar as

\footnotetext{
${ }_{19}$ Machado (2000) define a rastreabilidade como "um processo de práticas sistemáticas de segregação física e troca de informação entre os diferentes agentes da cadeia produtiva, responsáveis pela execução e cumprimento de uma meta específica de preservar os atributos e a identidade de produtos transacionados segundo suas especificações".
} 
transações. Quanto maior o grau de integração vertical na cadeia produtiva menor a redução no custo de transação. Assim, a coordenação de mercado apresenta o maior ganho de eficiência quando comparado com as formas hierárquica e híbrida.

Entretanto, apesar de vantagens coordenativas evidentes, a adoção de sistemas de classificação e padronização apresenta forte resistência, principalmente dos agentes envolvidos que se beneficiam da falta de transparência do mercado. A dificuldade de implementar e alterar um sistema de padronização em qualquer estrutura produtiva ocorre em razão da existência de interesses divergentes e conflitantes entre os diversos agentes.

No contexto da cadeia de FLV, a incerteza das transações permite o surgimento de oportunismo dos agentes envolvidos, tornando mais fortes as barreiras à padronização.

\subsection{A PADRONIZAÇÃO E O VAREJO MODERNO}

O atual padrão de competição da cadeia produtiva de FLV baseia-se cada vez mais na diferenciação de atributos de qualidade dos produtos. A crescente incorporação de atributos de crença ao conjunto de características preferidas pelo consumidor dificulta ainda mais a identificação direta da qualidade dos produtos, especialmente em ambientes que não apresentam um sistema efetivo de monitoramento de qualidade. Além da deficiência do ambiente regulatório, o fato das características dos FLV não serem facilmente observadas dificulta o pagamento de preços prêmios aos fornecedores de produtos com qualidade superior, uma vez que os agentes temem o comportamento oportunista da contraparte. A falta de sistemas que facilitem a identificação e comparação das diferenças qualitativas inibe a realização de investimentos em qualidade pelos agentes.

Especificamente, o varejo moderno está situado em uma posição

estratégica no interior da cadeia produtiva de FLV. A proximidade com o consumidor final torna o varejo moderno mais apto à captação de movimentos relativos às mudanças sócio-econômicas e estilo de vida da população. Ao mesmo 
tempo, está mais sujeito a prejuízos decorrentes da incerteza com relação à quantidade e qualidade dos produtos recebidos dos fornecedores.

Como discutido no capítulo 3 , a produção e comercialização de FLV apresentam alta especificidade de ativos, na qual o recebimento do preço prêmio depende da eficiência coordenativa das transações realizadas entre os diversos agentes verticalmente relacionadas na cadeia produtiva. A coordenação vertical estreita os vínculos com o consumidor final, facilitando o fluxo de informação e garantindo um produto específico.

Os elevados investimentos específicos necessários à produção de produtos que incorporem atributos de crença em um ambiente sem instrumentos de controle eficientes indicam que a forma organizacional hierárquica deveria prevalecer nas transações envolvendo FLV. Tanto o mercado quanto a hierarquia deixam de ser estruturas de governança eficientes para remunerar e monitorar adequadamente um produto de qualidade superior. Arranjos híbridos específicos baseados em contratos relacionais constituem a forma mais eficiente para sustentar as transações envolvendo os FLV.

A implementação de padrões e sistemas de classificação tem um impacto positivo sobre a coordenação vertical da cadeia produtiva de FLV ao reduzir os custos de transação e permitir a adoção de contratos relacionais com diferentes graus de idiossincrasias. Quanto mais confiável e efetivo for o sistema de classificação e padronização menor a necessidade de salvaguardas contratuais e, conseqüentemente, menores os custos de transação. No limite, a forma organizacional de mercado prevaleceria em transações com custo de transação nulo.

Um dos principais aspectos da organização da cadeia produtiva de FLV é a convivência de estruturas de governança de mercado e híbridas para reger transações semelhantes. $O$ alto grau de complementaridade ${ }^{20}$ das duas formas organizacionais permite que os agentes beneficiem-se das vantagens específicas de cada uma, dependendo das características individuais de cada transação.

\footnotetext{
${ }^{20}$ Para maior detalhamento ver seção 3.3.3.
} 
As novas estratégias adotadas pelo varejo moderno utilizam como mecanismo para melhorar a coordenação das transações na cadeia produtiva de FLV a criação de padrões privados próprios, que têm como objetivo principal informar a qualidade desejada dos produtos comercializados aos produtores e, ao mesmo tempo, atender às exigências de qualidade do consumidor.

Uma questão fundamental consiste em determinar qual tipo de informação o padrão privado deve transmitir para os agentes ao longo da cadeia produtiva e como provê-los de tal informação. A montante, o varejo moderno deve ter a capacidade de fornecer incentivos adequados para garantir o recebimento dos produtos em conformidade com o padrão exigido e, ao mesmo tempo, possuir instrumentos de controle eficazes para coibir a não conformidade. A jusante, o varejo moderno precisa transmitir a informação de que a conformidade com os padrões exigidos foi atingida para poder obter preço prêmio na comercialização do produto.

O surgimento indiscriminado de padrões privados, criados por diferentes agentes no interior da cadeia produtiva, afeta adversamente a coordenação vertical ao gerar um volume excessivo de informações diferentes e, às vezes conflitantes entre si, a respeito do mesmo produto, impedindo que o consumidor consiga identificar adequadamente a característica desejada, reduzindo a efetividade e a credibilidade do padrão. A credibilidade consiste em um fator importante para a efetividade do padrão privado.

A longo prazo, o conjunto de informações escolhido e a maneira de comunicação constituem a forma de sinalização empregada pelo varejo moderno para dar credibilidade ao padrão privado e transmitir as informações referentes aos atributos de crença incorporados aos FLV. Assim, a escolha da estratégia de sinalização mais adequada torna-se essencial para a resolução do problema.

O próximo passo consiste em discutir estratégia que o varejo moderno dispõe para fornecer credibilidade ao padrão privado e, ao mesmo tempo, transmitir a informação contida no padrão, objetivando o recebimento de preço prêmio, uma vez que a padronização, por se tratar de um bem coletivo, não 
oferece por si só os incentivos necessários para premiar produtos de qualidade superior.

\subsubsection{CREDIBILIDADE DA PADRONIZAÇÃO}

A efetividade da implementação de padrões e classificações a respeito da qualidade e segurança do produto requer que o agente promulgador disponha de credibilidade junto à sociedade. A credibilidade reflete a habilidade do agente, ou grupo de agentes, em garantir o cumprimento do compromisso firmado contratualmente, formalmente ou informalmente, a respeito da qualidade do produto final. A questão envolvendo os problemas de risco moral e seleção adversa sobre a escolha do nível de qualidade pelo agente pode ser interpretada como um problema de falta de credibilidade do agente com respeito à obrigação contratual.

No setor de FLV, o varejo moderno apresenta certo grau de dificuldade no desenvolvimento de estratégias que incutam confiança e satisfação ao consumidor e aos agentes a montante na cadeia produtiva. A grande importância dos atributos de experiência no setor de produtos frescos, as limitações do uso de marcas comerciais em razão da grande variabilidade das características dos produtos, motivada pela alta perecibilidade, e a elevação da importância dos atributos de crença constituem fatores que afetam negativamente a capacidade do varejo moderno em atender às necessidades dos agentes.

Em suma, a definição e garantia do padrão vêm se tornando cada vez mais dependentes das características específicas do processo de produção ao longo da cadeia de FLV que não podem ser observadas e verificadas somente pelos atributos de pesquisa dos bens. A adoção de estratégias empresarias específicas torna-se necessária para que o varejo moderno consiga dar credibilidade ao padrão privado próprio.

O presente estudo apresenta três estratégias que fornecem credibilidade ao padrão privado criado pelo varejo moderno: criação de marcas comerciais, certificação e relações de longo prazo. As duas primeiras formas referem-se a 
estratégias associadas somente às transações T4, compreendendo a relação do varejo moderno com o consumidor final. Já a última forma engloba tanto as estratégias voltadas para os agentes a montante na cadeia produtiva (produtores e atacadistas), representadas pelas transações T2 e T3, quanto à relação com o consumidor final (transação T4).

\subsubsection{ESTRATÉGIA DE CRIAÇÃO DE MARCA COMERCIAL}

O conceito original de marca vem sofrendo um rápido processo de transformação desde da década passada, expandindo seu alcance em várias direções. Atualmente, tudo pode ser visto como uma marca, desde uma caixa de cereal no supermercado até o nome de um museu famoso. A marca associada à qualidade do produto consiste em um dos mais valiosos ativos que uma companhia pode ter. Diversos trabalhos na literatura econômica identificam a construção da marca comercial como o método mais efetivo para os agentes informarem a qualidade de seus produtos aos consumidores (Codron, Sterns e Reardon, 2000; Rao e Monroe, 1989; Bagnara, 1996).

Uma marca envolve a imagem cultural, racional e emocional que o consumidor associa a determinada companhia ou produto. Cada vez mais consumidores estão interessados em qualquer assunto relacionado à marca, como, por exemplo, os ingredientes do produto, a história da companhia, a atitude e o comportamento da companhia em relação a questões ambientais.

A marca consiste em um nome específico usado para distinguir o produto de determinado vendedor, representando uma impressão geral sobre o produto, criada na mente do consumidor pelos atributos de qualidade extrínsecos e intrínsecos, nome e símbolo. A maioria dos produtos vendidos no comércio possui um nome e/ou símbolo bem definido, que identificam implicitamente algumas característica do produto. Como definido por Peri e Gaeta (1999), o nome da marca deve ter como característica a facilidade de reconhecimento e pronúncia; enquanto o símbolo deve associar o produto diretamente à marca, permitindo o desenvolvimento de uma imagem do produto perante o consumidor. 
De fato, a marca auxilia $\circ$ consumidor a identificar $o$ produto independentemente do local de aquisição, permitindo a redução dos custos de transação. Entretanto, não pode ser identificada como um sinal de qualidade superior, sendo somente um indicador mais estável e consistente do nível de qualidade no espaço e no tempo.

Outro elemento importante da marca consiste na garantia fornecida pelo varejista ao consumidor. A garantia constitui uma promessa informal que descreve o comprometimento da empresa em fornecer o produto conforme o padrão privado estabelecido. A falta de garantia eleva o custo de mensuração do produto devido à cuidadosa verificação dos atributos efetuada pelo consumidor. A credibilidade da marca associa-se diretamente às garantias fornecidas pelo varejista, sendo uma forma de reduzir a incerteza a respeito do produto.

Gryna (1992) identifica várias formas de marca comercial, que incluem marcas próprias de grandes comerciantes, de fabricantes, de franquias, de cadeia de produtos e de associações de indústrias. Uma estratégia recentemente adotada consiste na utilização, pelo varejo moderno, da marca da rede para a venda de produtos de fabricantes independentes, que são selecionados após rigorosos testes de qualificação. Bagnara (1996) constatou que as características do produto interagem com as características da loja, afetando diretamente a percepção de qualidade do consumidor. O objetivo da estratégia é associar a imagem de credibilidade que a rede possui junto ao consumidor ao produto de marca desconhecida que será vendido sob a marca da rede.

A utilização comum da marca comercial regulada por um conjunto de regras que devem ser seguidas por um grupo de agentes legalmente independentes transforma o uso individual em coletivo. A co-propriedade da marca impossibilita a utilização exclusiva por um único agente. Entretanto, a marca coletiva só poderá ser utilizada por pessoas que respeitem as regras de uso estabelecidas pelo mantenedor do registro.

Visando incutir credibilidade ao padrão privado, o varejo moderno pode usar a combinação de propaganda, promoção e distribuição repetida e contínua dos produtos com uma qualidade consistente com o padrão promulgado. Um dos 
objetivos da adoção de uma estratégia de criação de marca é diferenciar o produto dos concorrentes mais próximos, buscando aumentar o volume de venda. A diferenciação pode ser obtida tornando-o fisicamente diferente, pela utilização de embalagens especiais e variações no tamanho e forma, ou, então, alterando a percepção dos consumidores, por meio de atividades promocionais que mostrem a superioridade da qualidade do produto.

Com o sucesso da estratégia, o varejo moderno consegue associar a marca comercial própria ao produto vendido, de maneira que o consumidor consiga identificar diretamente os atributos de qualidade de pesquisa e crença dos FLV. A marca adiciona valor ao produto caso sua estratégia de criação tenha tido sucesso, permitindo que um preço mais alto seja cobrado por seu detentor. Geralmente, o consumidor possui maior confiança em produtos com marca, sendo capaz de pagar um preço prêmio pela qualidade superior, uma vez que a utiliza como um indicador crível da qualidade do produto (Rao e Monroe, 1989).

No setor de FLV a marca tem uso limitado em razão da perecibilidade dos produtos, sendo a reputação o principal determinante da sustentação da vantagem competitiva de sua utilização. Bagnara (1996) demonstrou que, no mercado de pêssegos frescos, o uso de uma marca que garanta a não utilização de pesticidas na fase de produção não é suficiente para aumentar o valor adicionado da fruta. No entanto, o uso da marca torna-se necessário para vender e manter a participação de mercado do referido produto.

Codron, Sterns e Reardon (2000) mostram que as estratégias baseadas na criação de marcas não foram totalmente bem sucedidas na França, apresentando custo e risco elevados para resultados pouco significantes. $\mathrm{O}$ aumento dos gastos na atividade de monitoramento e controle da qualidade dos produtos consiste na forma encontrada pelo varejo moderno para garantir que os investimentos realizados na construção da marca não sejam totalmente perdidos.

Em suma, a sustentação da estratégia de criação de marca no setor de FLV não encontrou ainda uma resolução adequada, em razão da dificuldade de manutenção de uma qualidade consistente ao longo do tempo dos atributos de pesquisa e experiência, em razão do rápido processo de deterioração dos 
produtos. O investimento na construção da reputação por comportamento confiável trata-se da forma adequada para a sustentação da estratégia de criação de marca comercial.

\subsubsection{ESTRATÉGIA DE CERTIFICAÇÃO}

Os conceitos de certificação e padronização apresentam várias similaridades, embora sejam distintos entre si. Sob o ponto de vista da coordenação de sistemas agroindustriais, a certificação é vista como uma padronização mais detalhada, que possui mecanismos de exclusão para os usuários que violarem as regras preestabelecidas. A certificação fornece credibilidade à padronização, sendo exigida em situações nas quais a padronização apresente um nível elevado de complexidade, tornando-se, assim, insuficiente para $\mathrm{o}$ atendimento das necessidades dos agentes. A literatura francesa utiliza o conceito de padrão de referência para se referir à certificação (OECD,1997).

Essencialmente, a certificação pode ser coletiva, quando um órgão certificador especializado coordena o estabelecimento de regras e mecanismos de controles, ou interna, quando se associa a sub-sistemas estritamente coordenados criados especialmente para reduzir o custo de transação. No segundo caso, a empresa opta em criar um sistema próprio quando as alternativas oferecidas no ambiente institucional não atendem suas necessidades. $O$ desenvolvimento de um certificado privado consiste em uma estratégia de diferenciação de produto que não exige investimentos tão elevados quanto o estabelecimento de uma marca comercial. Paralelamente, do ponto de vista de processamento e alteração industrial, o produto certificado é idêntico ao semelhante não certificado. A certificação privada adiciona valor ao produto sem, necessariamente, acrescentar mais transformação ao produto (Nassar, 1999).

Machado (2000:79) entende que a certificação refere-se a um instrumento formal que garante especificações de qualidade preestabelecidas sobre o produto. Assim, a certificação consiste na definição de atributos de um produto, processo 
ou serviço, e na garantia de que eles se enquadram em normas pré-definidas, podendo ser emitido por instituições independentes (privada, pública, nacional ou internacional) com poder de monitoramento e exclusão (Nassar, 1999).

Como salientado por Nassar (1999), similarmente aos conceitos de padronização e rastreabilidade, a certificação pode ser analisada dentro do arcabouço teórico compreendido pela coordenação vertical das cadeias produtivas, pois tem como objetivo garantir a qualidade dos produtos certificados, segundo as necessidades e desejos específicos dos agentes da cadeia (consumidores, intermediários, varejistas, etc.).

Ao estabelecer determinados procedimentos e padrões, a certificação permite que as empresas participantes controlem a qualidade do produto e garantam o uso de um conjunto de atributos, criando um processo dinâmico de exclusão e seleção de firmas e produtos. Outro objetivo da certificação consiste no fornecimento de informação ao consumidor sobre determinados atributos dos produtos, reduzindo as assimetrias informacionais e aumentando a eficiência dos mercados. Dentro de tal contexto, a certificação é entendida como um sinal de qualidade fornecido por uma instituição formal, externa ao mercado, que se responsabiliza pela veracidade das informações contidas no certificado.

A certificação pode transformar uma commodity em um produto especializado enquanto o certificado privado não for dominante no mercado. Ao mesmo tempo, a certificação privada pode ser um eficiente instrumento de sustentação e apoio de marcas privadas e, em alguns casos, ser mais importante ao consumidor do que a marca. O quadro 4 apresenta uma comparação entre certificado e marca.

O uso da certificação na cadeia produtiva de FLV é mais indicado quando os padrões adotados utilizam processos produtivos específicos ou baseados em atributos diferenciados, tratando-se de uma ferramenta que reduz os custos de transação e melhora o desempenho da cadeia produtiva.

Segundo Codron, Sterns e Reardon (2000), o surgimento indiscriminado de diversos tipos de certificados ameaça a efetividade dos mesmos ao confundir os consumidores. Baines e Davis (1997) mostram que a proliferação de certificados 
de garantia de qualidade no Reino Unido tem atrapalhado a coordenação de cadeias produtivas ao confundir os agentes sobre quais atributos intrínsecos e extrínsecos cada certificado está garantindo. Por exemplo, os novos consumidores carecem de experiência anterior de consumo e têm pouco conhecimento acerca de características peculiares do produto, não conseguindo diferenciar corretamente os diversos certificados (Boccaletti, 2000:6).

QUADRO 4: COMPARAÇAO ENTRE CERTIFICADO E MARCA

\begin{tabular}{|c|c|c|}
\cline { 2 - 3 } \multicolumn{1}{c|}{} & CERTIFICADO & MARCA \\
\hline Características & $\begin{array}{c}\text { Instrumento coletivo } \\
\text { Estratégias do sistema ou da indústria }\end{array}$ & $\begin{array}{c}\text { Instrumento privado } \\
\text { Estratégias da firma }\end{array}$ \\
\hline Responsabilidade & Organização certificadora (árbitro) & Firma possuidora da marca \\
\hline $\begin{array}{c}\text { Objetivos } \\
\text { Principais }\end{array}$ & $\begin{array}{c}\text { Garantir os atributos dos bens } \\
\text { Incremento em qualidade }\end{array}$ & $\begin{array}{c}\text { Representar os atributos do produto } \\
\text { Manter ou elevar participação de mercado } \\
\text { Segmentação e diferenciação }\end{array}$ \\
\hline $\begin{array}{c}\text { Resultados } \\
\text { Secundários }\end{array}$ & $\begin{array}{c}\text { Ampliar a participação de mercado } \\
\text { Criar barreiras à entrada } \\
\text { Segmentação e diferenciação }\end{array}$ & $\begin{array}{c}\text { Promover a qualidade do produto } \\
\text { Regulamentação }\end{array}$ \\
\hline Fonte: Adaptado de Nassar (1999) & Específica & Não específica* \\
\hline
\end{tabular}

O sucesso da utilização da estratégia de certificação de FLV depende da capacidade de monitoramento, do poder de exclusão e da reputação da organização externa escolhida para garantir a conformidade com os padrões privados adotados pelo varejo moderno. Há diversas formas de certificação empregadas no setor, como a utilização de rótulos, selos de sanidade e pureza entre outros.

Normalmente, o Estado e/ou instituições internacionais constituem-se os principais agentes regulamentadores. O surgimento espontâneo de um sistema de certificação não ocorre comumente no interior da cadeia produtiva, cabendo a entidades externas a elaboração das regras. Em situações de falta de um sistema de regulamentação institucional governamental, o surgimento da certificação é prejudicado ou inviabilizado. Neste caso, a organização externa independente tem como função básica especificar as características usadas como padrão, monitorar a conformidade de tais características e emitir um certificado de conformidade. A 
credibilidade do certificado baseia-se nos monitoramentos (ex-ante e ex-post) realizados pela terceira parte externa às transações.

A legitimidade das instituições formais de certificação pode ser garantida pelo Estado ou por meio da reputação adquirida por uma organização privada independente que se responsabilizará pela veracidade das informações fornecidas.

\subsubsection{ESTRATÉGIA BASEADA EM RELAÇÕES DE LONGO PRAZO}

O estabelecimento de relações de longo prazo entre o varejo moderno e consumidores, atacadistas e produtores tem como objetivo associar os atributos de qualidade desejados de experiência e crença a um particular local ou agente, ao invés de uma determinada marca comercial ou certificação.

A efetividade da estratégia está diretamente ligada à confiança que o varejo moderno conquista junto aos demais agentes ao longo do período de relacionamento comercial. A manutenção da relação garante a credibilidade do padrão privado promulgado pelo varejo moderno.

Entretanto, a ocorrência de qualquer divergência nas expectativas dos agentes quanto aos atributos específicos padronizados ameaça a manutenção do relacionamento. A estratégia baseia-se sobretudo em investimentos específicos realizados na reputação do varejo moderno, não sendo produto específica.

Em geral, para a transação T4, a estratégia baseada em relações informais de longo prazo predomina no interior das lojas do varejo moderno e, principalmente, no departamento de FLV, em virtude do custo inferior de implementação e pelo fato de apresentar menor risco associado à transação quando comparada com as duas estratégias anteriores (certificação e marca comercial).

De forma semelhante, as transações T2 e T3 baseiam-se em acordos recíprocos de longo prazo em virtude da forma organizacional de mercado não conseguir atender à demanda crescente do varejo moderno por produtos de 
qualidade superior ${ }^{21}$. Tais relações de longo prazo permitem a proteção dos investimentos requeridos para a construção da credibilidade do padrão privado, melhorando a coordenação das transações. Em geral, baseia-se em contratos formais de longo prazo que incorporam garantias contra ações oportunistas.

O estabelecimento de relações de longo prazo apresenta riscos para ambas as partes envolvidas na transação. Os riscos do varejo moderno consistem no fornecimento de produtos de baixa qualidade e o não cumprimento dos prazos de entrega estabelecidos. Por outro lado, o fornecedor está permanentemente exposto ao risco de quebra contratual pelo varejo moderno, representando a perda completa dos investimentos específicos realizados para atender as especificações dos padrões privados. $\mathrm{O}$ aumento da dependência bilateral entre as partes reduz os riscos dos agentes.

A continuidade do relacionamento permite a redução gradativa das salvaguardas contratuais e, conseqüentemente, a diminuição dos custos de transação. A reputação por comportamento confiável torna-se fator chave para a redução dos custos de transação ${ }^{22}$.

\subsubsection{A ADOÇÃO DE UM MIX DE ESTRATÉGIAS}

As três estratégias apresentam elevada interdependência, podendo ser complementares ou contraditórias. Em geral, o varejo moderno adota uma combinação de estratégias para criar e manter a credibilidade do padrão privado próprio junto aos demais agentes envolvidos nas transações T2, T3 e T4.

Por exemplo, a designação de origem (DO) representa um tipo de certificação de qualidade que utiliza basicamente indicações do local de origem do produto como um fator de diferenciação. Trata-se da representação de uma marca institucional que assegura ao consumidor a região geográfica de origem do FLV e que o produto foi produzido conforme o padrão definido pelo certificado. A

\footnotetext{
${ }^{21}$ Ver item 3.3.2.

${ }^{22}$ Ver item 2.2.4.
} 
principal função consiste em ser um indicador confiável dos atributos de qualidade de crença, facilitando a diferenciação do produto.

Em geral, a DO utiliza uma denominação comercial específica da área geográfica de origem para diferenciar o produto dos potenciais substitutos. A administração do certificado é realizada por um grupo nomeado, encarregado de controlar e desenvolver as atividades, e implementar um sistema de controle efetivo com o objetivo de garantir a aplicação de regras comuns de produção. Uma conseqüência direta para os agentes sob a certificação refere-se ao surgimento do efeito reputação em razão da criação da $D O$, que fornece credibilidade coletiva a toda produção proveniente de determinado local. A DO só será um indicador confiável de qualidade se o consumidor conseguir inferir sobre os atributos de experiência e crença do produto.

A utilização de selos de DO consiste em uma estratégia que utiliza elementos inerentes tanto à marca comercial quanto à certificação (Quadro 4). Ao mesmo tempo, a continuidade da relação permite ao consumidor adquirir confiança com respeito ao selo.

Em suma, as três estratégias apresentadas nas seções anteriores têm como objetivo principal comum diferenciar o produto com qualidade superior, fornecendo credibilidade ao padrão privado criado pelo varejo moderno. Trata-se de estratégias que podem se expandir ao longo de toda a cadeia produtiva de maneira concomitante, buscando atender as diferentes demandas dos consumidores.

A presença do efeito reputação é essencial para o funcionamento das três estratégias de credibilidade. A reputação aumenta a confiança dos agentes sobre marcas, empresas certificadas, empresas certificadoras e do próprio varejo moderno, permitindo a obtenção de preços prêmios por produtos com qualidade superior comprovada. Segundo Machado (2000), a tendência atual consiste em sinalizar a qualidade dos alimentos por meio do efeito reputação tanto da marca e da certificação do produto quanto da entidade certificadora e da contra-parte. 


\subsubsection{SINALIZAÇÃO DA PADRONIZAÇÃO}

A ECT mostra que a existência de informação imperfeita e assimétrica provoca o surgimento de custos de transação que prejudicam a coordenação eficiente da cadeia produtiva. Duas questões cruciais que surgem no momento da adoção de estratégias que fornecem credibilidade ao padrão privado consistem na determinação de qual tipo de informação o padrão privado deve transmitir aos agentes ao longo da cadeia produtiva e como provê-los de tal informação.

Os consumidores continuamente efetuam escolhas entre diversos produtos à sua disposição, não somente sujeitos à carência de informação a respeito do preço dos bens, mas, provavelmente, também dispondo de escassez de informação com relação à variabilidade da qualidade do bem adquirido, devido ao elevado custo e à dificuldade de obtenção de tais informações. O equilíbrio alcançado em tais mercados apresenta um nível de qualidade inferior ao ótimo, proporcionando perdas de bem-estar aos agentes econômicos (Akerlof, 1970). Como discutido por Nelson (1970), limitações na informação do consumidor a respeito da qualidade têm efeitos negativos sobre a estrutura de mercado.

$\mathrm{O}$ varejo moderno deve ter a capacidade de fornecer incentivos adequados aos agentes que se encontram acima na cadeia produtiva, para garantir o recebimento dos produtos em conformidade com o padrão exigido e, simultaneamente, possuir instrumentos de controle eficazes para coibir a não conformidade. Assim, os agentes necessitam comunicar a implementação de padrões e classificações a respeito da qualidade e segurança do produto para tornar efetiva a estratégia de diferenciação empregada. $O$ incentivo para convencer outros agentes que os produtos realmente possuem determinadas características é elevado para o varejo moderno.

Uma terceira questão crucial que surge refere-se ao fato de que a adoção indiscriminada de diferentes estratégias de credibilidade no interior da cadeia produtiva acentua a dificuldade de identificação dos atributos preferidos em razão da capacidade cognitiva limitada dos agentes. A criação de um mecanismo que permita ao detentor de produtos em conformidade com padrões e classificações 
informar aos compradores a diferença de qualidade torna-se racional e desejável, tanto do ponto de vista do consumidor quanto do vendedor. O uso de um sinal crível, contendo informação relevante sobre a adoção do padrão privado, enviado ao longo da cadeia produtiva, restabelece parte da eficiência do mercado ao reduzir a quantidade de informação privada.

A sinalização baseada na garantia de qualidade dos produtos consiste em um mecanismo que permite a transmissão correta de informações sobre as características desejadas do produto aos diversos agentes da cadeia produtiva. A utilização de sinais de qualidade reduz e limita a assimetria informacional, amenizando os efeitos adversos na coordenação eficiente da cadeia.

O sinal de qualidade pode ser visto como um resumo informativo que fornece as características do produto ou da atividade de produção. A exposição do produto a partir do sinal (logotipo, símbolo, marca, certificado, entre outros) permite ao consumidor identificar e reconhecer imediatamente o bem e, indiretamente, inferir sobre algumas características do produto que não são perceptíveis no momento da compra.

Segundo a visão de Klein e Leffer (1981), o sinal de qualidade refere-se a um conjunto de promessas a respeito da qualidade futura do bem contidas em um contrato, informal ou formal, mantido pelas partes envolvidas na transação. A abordagem permite a análise dos mecanismos contratuais que encorajariam os agentes a produzir o bem com o nível de qualidade anunciado pelo sinal. Dentro de tal contexto, o sinal pode envolver, por exemplo, o compromisso de um nível de qualidade consistente no espaço e no tempo (padronização), ou a garantia de que os produtos não contêm determinados elementos (segurança de alimentos), ou a garantia que o processo produtivo não utiliza determinada tecnologia, ou, então, garantia que o produto é proveniente de determinada área geográfica (DO).

Quatro elementos fundamentais definem a identidade e a função de comunicação do sinal de qualidade de um produto (Peri e Gaeta 1999):

a) Um sinal de qualidade deve ser rapidamente identificável e reconhecido;

b) Entende-se a qualidade como um sinal de especificidade, pois indica diferenças ou distinções em relação a padrões de referência; 
c) A qualidade consiste em um sinal de conformidade com padrões, devendo a especificidade ser mensurável, verificável e controlável, ou seja, mantida sob controle no processo de produção;

d) A qualidade consiste em um sinal de reafirmação e garantia de atributos e especificidades prometidos ao consumidor.

Segundo Machado (2000:66), os dois primeiros elementos englobam as características que permitem ao consumidor reconhecer a qualidade do produto, enquanto os dois últimos elementos representam o custo pago pela empresa para manter e garantir a conformidade do produto com padrões estabelecidos e a credibilidade da imagem do produto associada aos atributos de especificidade do primeiro grupo. A ausência de qualquer elemento reduz a eficiência do sinal de qualidade como transmissor de informação aos agentes.

Existem diversas formas alternativas de adicionar informação relevante ao produto por meio da sinalização. A escolha entre diferentes alternativas de sinais de qualidade ou a combinação de alternativas tem importantes implicações, tanto no longo quanto no curto prazo, sobre a reputação da firma, seu produto ou serviço e a eficiência com que conduz o negócio. O surgimento do sinal de qualidade pode ser resultado da iniciativa de um produtor individual ou de um grupo de produtores interessados em criar um sinal comum de qualidade, ou, então, do Estado.

Sporleder e Goldsmith (2001) agrupam em quatro classes as formas alternativas de sinalização de qualidade. A primeira classe consiste nas estratégias que utilizam protocolos e procedimentos de terceiras partes para monitorar a conformidade de padrões e classificações sobre a qualidade de produtos e processos. O controle é realizado por entidades públicas e privadas conceituadas e externas à cadeia produtiva. A efetividade do sinal depende da capacidade de alterar rapidamente as normas pelas terceiras partes frente às mudanças do ambiente institucional. Em geral, as entidades privadas apresentam maior velocidade de resposta do que o órgão público regulamentador, em razão dos problemas burocráticos e políticos inerentes ao processo de implementação de novas regras. 
Uma segunda classe de sinalização baseia-se em estratégias de diferenciação do produto pela marca comercial e/ou reputação da firma. A reputação associada à determinada marca refere-se à confiança do consumidor na integridade do agente provedor do produto. A marca consiste em um mecanismo eficiente para transmitir informação crível a respeito da qualidade dos produtos, mas a perecibilidade dos FLV limita o seu uso pelos agentes ${ }^{23}$.

A terceira classe descrita por Sporleder e Goldsmith (2001) refere-se a estratégias de compensação como seguros e garantias sobre a qualidade dos produtos. Ao fornecer garantias a respeito da qualidade do bem o agente consegue sinalizar confiabilidade quanto às características de crença do produto. Entretanto, tal classe tem uso limitado no setor FLV em virtude da dificuldade de percepção do instante exato que as características do produto se alteraram, dificultando o estabelecimento de prazos de validade.

A última classe inclui a utilização de alianças estratégicas ${ }^{24}$ e de integração vertical para assegurar a sinalização dos atributos de qualidade. A incerteza é reduzida em virtude da comunicação entre os agentes tornar a informação mais precisa e completa ao longo dos estágios verticais da cadeia produtiva, permitindo o surgimento de ganhos de eficiência.

As diversas classes de mecanismos de sinalização fornecem várias opções para o varejo moderno informar a diferenciação do produto. Não existe, entretanto, uma solução global ótima para o problema que depende essencialmente das características dos atributos das transações e do ambiente institucional no qual as transações estão inseridas.

\subsubsection{INTERAÇÃO DOS MECANISMOS DE CREDIBILDADE E SINALIZAÇÃO}

Os dois grupos de estratégias baseados em mecanismos de sinalização e credibilidade de padrões e classificações apresentam grande similaridade. Por

\footnotetext{
${ }^{23}$ Maiores esclarecimentos na seção 4.4.1.1

${ }^{24}$ Sporleder et al. (1998) definem as alianças estratégicas como relações formais verticais baseadas no compartilhamento de objetivos comuns que visam facilitar a coordenação e aumentar a eficiência da cadeia produtiva, como, por exemplo, joint ventures.
} 
exemplo, a utilização de marcas comerciais fornece credibilidade e, ao mesmo tempo, sinaliza a diferenciação do produto. Do mesmo modo, a utilização de certificados e o emprego de protocolos e procedimentos por terceiras partes sobre a qualidade dos produtos e processos apresentam características semelhantes. Em geral, existe um elevado grau de complementaridade entre as estratégias de credibilidade e sinalização.

A necessidade de realização de elevados investimentos pelo varejo moderno para a construção do sinal de qualidade e da credibilidade provoca o aumento dos gastos com sistemas de monitoramento para defender os investimentos realizados. A possibilidade de redução dos investimentos incentiva a utilização de estratégias que simultaneamente forneçam credibilidade e sinalizem a diferenciação da qualidade do produto.

Ao mesmo tempo, a utilização simultânea dos mecanismos de credibilidade e sinalização torna-se necessária para que $o$ processo de criação $e$ implementação de padrões privados pelo varejo moderno seja bem sucedido. Em geral, a forma mais disseminada na cadeia de FLV consiste na utilização combinada dos dois mecanismos. Entretanto, a falta de qualquer um deles tornará qualquer tentativa de introdução de padrões privados fadada ao fracasso.

\subsubsection{O EFEITO CARONA (FREE RIDER)}

Tanto o uso comum da marca quanto à designação de origem podem gerar um problema de oportunismo conhecido na literatura como free-rider ou efeito carona. O problema surge quando um agente que utiliza uma marca comercial coletiva altera alguma característica relevante do produto para obter um ganho extra imediatamente em razão da redução do custo. $O$ agente continuaria se beneficiando do sinal de qualidade fornecido pela marca sem atender ao conjunto de regras estabelecidas para seu uso. $O$ efeito da perda de credibilidade da marca junto ao consumidor insatisfeito com o produto adquirido fora das especificações será sentido por todos os agentes que utilizam a marca coletiva. A redução futura na demanda não afetará somente o free-rider, provocando prejuízos para toda a 
coletividade. O efeito é intensificado quando a possibilidade de compras repetidas é extremamente baixa, como em lojas localizadas em auto-estradas.

Quando detectada a ocorrência do comportamento free-rider, a possibilidade de imposição de sanções visa principalmente inibir a ação oportunista futura dos agentes. Sob a forma de restrições contratuais, na maioria dos casos a penalidade consiste no término do uso da marca coletiva pelo agente que infringiu as regras do sinal de qualidade.

O término da relação implica em perdas de quase-rendas futuras para os agentes. Se a estimativa do valor presente descontado do fluxo de quase-rendas for superior à estimativa do lucro extra no curto prazo, o agente não terá incentivos para desenvolver um comportamento oportunista, evitando o rompimento do contrato.

\subsubsection{O PAPEL DA REPUTAÇÃO}

O papel da reputação em todo o processo é fundamental, uma vez que atua como um mecanismo de sustentação da credibilidade do padrão privado, do varejo moderno e do sinal de qualidade transmitido aos demais agentes da cadeia produtiva, conforme discutido nas seções anteriores.

Nas transações envolvendo produtos que apresentam grande quantidade de atributos de crença, como os FLV, os agentes utilizam as transações passadas como indicador das qualidades presente e futura dos produtos. A reputação aumenta a quantidade de informação disponível no instante de concretização da transação, ao garantir que um conjunto de promessas sobre determinadas características do bem ou serviço transacionado permaneça consistente ao longo do tempo. Assim, a boa reputação do produto ou da firma fornecedora afeta positivamente a venda de bens e serviços, enquanto a má reputação pode conduzir uma empresa à falência.

O desenvolvimento de reputação por comportamento confiável entre os agentes permite a redução de salvaguardas contratuais e a necessidade de inspeção técnica especializada nas transações, diminuindo os efeitos adversos da 
existência de informação imperfeita e assimétrica.

Devido à necessidade de um período de tempo para sua criação e por facilitar o desenvolvimento de qualquer atividade produtiva para seu detentor, a reputação tem grande valor econômico. A reputação de uma firma trata-se de um ativo valioso, podendo estar associada tanto à marca comercial (Shapiro, 1983), quanto à certificação e às relações de longo prazo. Trata-se de uma relação extremamente frágil entre os agentes envolvidos, sendo passível de perda por qualquer movimento errôneo.

Em geral, as empresas procuram construir a reputação de qualidade do produto a partir da marca comercial (Klein e Leffer, 1981, Shapiro, 1983). A marca pode ser classificada como um ativo intangível que fornece ao consumidor uma garantia subjetiva a respeito da uniformidade do produto, permitindo a redução dos custos de mensuração. Conseqüentemente, qualquer organização ou indivíduo deve constantemente preocupar-se com a reputação de sua marca. $\mathrm{O}$ correto gerenciamento da reputação protege o valor de longo prazo da marca, que em muitos casos pode exceder o valor dos ativos tangíveis das corporações ou dos indivíduos.

A reputação, por outro lado, consiste em um conceito mais amplo que denota a soma dos conhecimentos desenvolvidos pelo consumidor com relação a determinada organização ou pessoa ao longo do tempo. Além da marca, a reputação inclui a performance do produto, onde o consumidor utiliza as experiências passadas como forma de julgamento; a qualidade que o consumidor espera encontrar no produto baseado no preço, posicionamento de mercado, propaganda e nível de performance inerente; o serviço que é oferecido ao consumidor, incluindo os diferentes níveis de distribuição, instalação e outras formas de relacionamento entre consumidor e empresa; e o apoio de marketing (propaganda, embalagem e atividades promocionais). O estabelecimento da reputação da marca envolve custos elevados que podem ser facilmente perdidos se o vendedor não utilizar um sistema de controle eficiente que assegure a uniformidade dos atributos dos produtos.

De modo similar, o efeito reputação representa um mecanismo eficaz para 
gerar e manter a credibilidade do agente, sustentando a estratégia de certificação por terceiras partes e as relações de longo prazo entre os agentes. A formação da reputação trata-se também de uma atividade que envolve a transmissão de informação, uma vez que a qualidade dos bens produzidos previamente serve como um sinal da qualidade dos bens produzidos no período corrente (Shapiro, 1983). A figura 5 mostra o relacionamento entre os elementos mencionados para a formação da reputação das estratégias de credibilidade (marca, certificado e relacionamento de longo prazo) e sinalização.

FIGURA 5: FORMAÇÃO DA REPUTAÇÃO

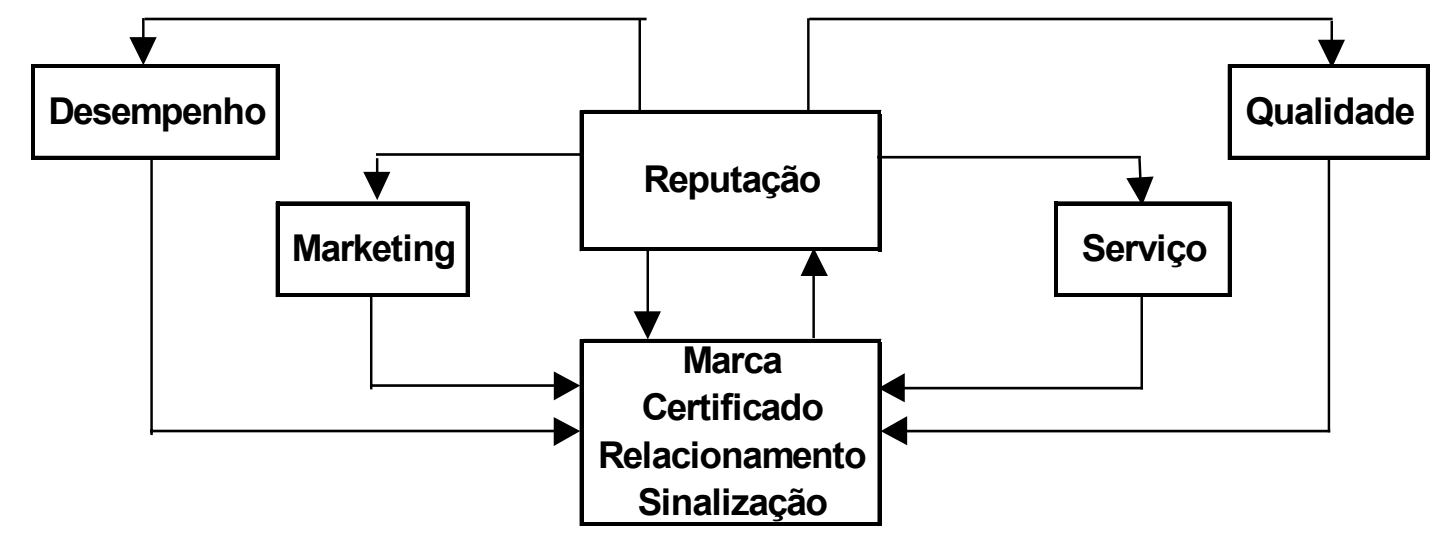

Fonte: Elaboração do autor

A decisão da firma de produzir bens de alta qualidade consiste em um processo dinâmico, onde os benefícios associados a tal decisão surgem somente no futuro, por meio do efeito reputação que é construído lentamente ao longo dos anos.

A construção da reputação requer um período inicial de investimento, onde o agente deve comercializar o produto com preço inferior ao custo, uma vez que, enquanto a reputação não for estabelecida, a obtenção do preço associado a bens de alta qualidade não é possível. A necessidade de investimento na formação da reputação implica que, no equilíbrio, os produtos de qualidade superior devem ser vendidos a um preço prêmio acima do custo de produção. O prêmio representa uma recompensa pelo investimento inicial na construção da reputação (Shapiro, 
1983).

Ao mesmo tempo, o ganho obtido com o prêmio tem um papel central na manutenção da reputação do vendedor ou firma. A falta de recompensa pela produção de itens de alta qualidade permitirá o aparecimento da estratégia fly-bynight de redução de qualidade em busca de maximização do lucro. Tal situação refere-se à possibilidade de obtenção de lucros superiores de curto prazo por meio da redução da qualidade do bem comercializado. A perda da reputação provocada pela utilização de tal estratégia ocorrerá somente no longo prazo, permitindo ao agente obter uma receita adicional de imediato. A estratégia é dominante uma vez que lucros positivos são obtidos pelos agentes. Entretanto, como explorado por Klein e Leffer (1981), a estratégia fly-by-night não será dominante quando a estratégia de fidelidade via manutenção da qualidade também gerar um fluxo de lucros positivos no longo prazo suficiente para compensar o ganho de curto prazo.

Kreps (1990: 119) observa que a eficácia do efeito reputação em garantir contratos implícitos depende do fato dos termos contratuais não serem ambíguos e da capacidade da sociedade observar e transmitir por meio de redes de comunicação o comportamento dos agentes. A possibilidade de perda da reputação conduz o agente, ou grupo de agentes, a desenvolver sistemas eficazes de controle, interno ou externo, nas suas relações comerciais, objetivando manutenção dos ganhos advindos de preços prêmios e da confiança dos demais agentes. A manutenção da reputação torna-se um instrumento de incentivo eficiente para inibir o comportamento oportunista ao longo da cadeia produtiva.

\subsubsection{VISÃO GERAL DO PROCESSO DE MUDANÇA INSTITUCIONAL}

O conjunto dos capítulos 3 e 4 fornece uma visão detalhada da dificuldade de todo o processo de transformação que a cadeia produtiva de FLV vem enfrentando para acompanhar as mudanças do ambiente institucional. O processo de adoção de diferentes estratégias que visam implementar a padronização e classificação dos FLV permite o aumento da eficiência coordenativa da cadeia produtiva, gerando a redução dos custos de transação e a adoção de formas 
organizacionais híbridas para sustentar as transações entre os agentes.

Quando o Estado não consegue prover adequadamente o ambiente institucional de mecanismos eficazes de coerção para sustentar padrões mínimos de referência para a qualidade dos produtos comercializados no interior da cadeia produtiva de FLV, incentiva o surgimento de padrões desenhados por empresas privadas na busca de instrumentos que permitam diferenciar seus produtos.

Axelrod (1997) sustenta que a reputação consiste em um importante, e freqüentemente dominante, mecanismo utilizado para sustentar uma norma privada ou pública ao criar um sinal a respeito do comportamento individual. A violação da norma cria um sinal adverso a respeito do comportamento futuro do indivíduo, representando uma elevada perda de receita para os agentes.

Em geral, o surgimento de normas e regras inicialmente ocorre informalmente na sociedade em razão da morosidade do aparato legal, que enfrenta problemas relacionados a burocracia e a questões políticas. Ao mesmo tempo, o dinamismo do processo competitivo impossibilita os agentes privados de aguardar o final do processo de formação de leis e normas formais. Assim, a utilização informal de normas próprias por agentes privados visa a rápida adaptação ao novo padrão competitivo enquanto a norma formal não é definida. A falta de um aparato legal para resolver eventuais conflitos entre os agentes faz com a reputação tenha um papel fundamental como redutor de custos de transação em um ambiente institucional governado por relações informais.

O surgimento da norma formal pode ocorrer a partir do sinal gerado pela reputação de um determinado comportamento que é premiado ou punido no interior da sociedade. De fato, a continuidade da utilização informal, no ambiente institucional, de determinadas regras e normas pelos indivíduos provoca a formação da reputação, positiva ou negativa, servindo como um sinal informativo para formalização da regra informal no futuro. O papel do efeito reputação consiste em fornecer a sustentação necessária para inibir o comportamento oportunista de curto prazo dos agentes no processo de mudança institucional ao longo da cadeia produtiva.

O processo de criação de sistemas de classificação e padrões na cadeia de 
FLV enquadra-se perfeitamente neste cenário. A alteração do padrão de comercialização vigente pelo varejo moderno, por meio da implementação de estratégias que visam agregar qualidade e valor aos FLV, objetiva melhorar a coordenação da cadeia produtiva, criar sistemas eficientes de incentivos, reduzir o comportamento oportunista e estimular o aparecimento de instituições públicas e/ou privadas de controle. A reputação do varejo moderno, os mecanismos de credibilidade e sinalização fornecem a base de sustentação de todo o processo, permitindo a redução dos custos de transação.

A capacidade de resposta do ambiente institucional frente às mudanças do padrão competitivo trata-se de um fator importante para avaliar a eficiência coordenativa da cadeia produtiva. O próximo passo consiste em comparar a cadeia produtiva de FLV na Holanda e no Brasil, que apresentam níveis de capacidade adaptativa diferentes e, conseqüentemente, diferentes graus de eficiência coordenativa. 


\section{AS CADEIAS PRODUTIVAS DE FLV HOLANDESA E BRASILEIRA}

No presente capítulo realiza-se um estudo comparativo entre as cadeias produtivas de FLV na Holanda e no Brasil, objetivando verificar a influência do ambiente institucional no desenvolvimento do setor. O capítulo mostra que a capacidade adaptativa do ambiente institucional de cada país, frente às mudanças do padrão competitivo, constituiu em fator de diferenciação da eficiência coordenativa da cadeia produtiva. O fato da cadeia de FLV holandesa encontrarse em uma fase de desenvolvimento mais avançada que a cadeia brasileira, em razão da melhor eficiência adaptativa do ambiente institucional, favoreceu o estabelecimento da padronização e de sistemas ótimos de distribuição. A metodologia da ECT permite identificar problemas potenciais no processo de modernização do sistema de distribuição brasileiro e desenvolver propostas de medidas corretivas por meio da análise institucional comparativa.

Inicialmente, apresenta-se as características do setor de FLV para cada país e, em seguida, comenta-se as semelhanças e diferenças das cadeias produtivas. Um dos objetivos do capítulo consiste na investigação das novas estratégias adotadas pelos agentes envolvidos na comercialização de FLV para enfrentar as mudanças no padrão de competição do setor na Holanda e no Brasil.

\subsection{A CADEIA HOLANDESA DE FLV}

O setor agrícola holandês é considerado um dos mais desenvolvidos do mundo. Apesar da área territorial reduzida, a Holanda apresenta um setor de produção de alimentos com elevada capacidade produtiva. A localização geográfica privilegiada, na foz dos principais rios europeus, favoreceu 0 estabelecimento do país como uma região de passagem obrigatória das mercadorias do continente, permitindo o desenvolvimento de sistemas de distribuição especializados. Martin e Hughes (1993) atribuem como principal fator de sucesso do setor agrícola do país o excelente sistema de distribuição de 
mercadorias, que consegue interligar eficientemente todos os agentes da cadeia produtiva.

Visando fortalecer o papel de centro de distribuição, o país realiza investimentos em infra-estrutura continuamente, tendo como objetivo a redução de custos e a melhoria do desempenho. O Porto de Roterdã, por exemplo, tornou-se ponto de referência em termos de entrada e saída de produtos agrícolas da Europa, sendo desde 1962 o porto que movimenta maior quantidade de carga no mundo, além de apresentar baixos custos.

Zylbersztajn et al. (1992) entendem que o sucesso holandês deve-se à conjunção de alguns fatores, como, por exemplo, condições de produção eficientes, proximidade a grandes mercados consumidores e forte estrutura cooperativista. A posição de destaque, em termos de competitividade no setor agrícola, foi alcançada paulatinamente ao longo do último século, sendo que o conhecimento histórico de todo processo permite melhor entendimento do grande sucesso agrícola holandês.

\subsubsection{ANTECEDENTES}

Ao longo dos séculos, a Holanda apresenta uma história de busca contínua de oportunidades comerciais para seus produtos no exterior. Desde a crise agrícola mundial de 1880, o Estado holandês tem procurado identificar aspectos limitantes da atividade agrícola e buscado ativamente construir um ambiente institucional que permitisse ao produtor rural atuar com extrema eficiência.

A influência governamental foi decisiva para redução da desorganização e melhoria da cooperação entre os agentes no setor de FLV. A criação de institutos e universidades voltados para pesquisa especializada na área agrícola, realizada pelo Estado, proporcionou um elevado ganho de produtividade no setor, ao promover uma maior difusão do conhecimento.

Paralelamente, o pequeno produtor sem poder de negociação organizou-se em cooperativas de produtores agrícolas, visando aumentar o poder de barganha nas transações com fornecedores de insumos e compradores da produção. $O$ 
crescimento das cooperativas ocorreu naturalmente, com pouca interferência do Estado, em diversos setores agrícolas. A criação de leilões pelas cooperativas para negociar a produção, no início do século $X X$, favoreceu a organização dos produtores em torno de objetivos comuns, permitindo melhorar o fluxo de informação e garantir níveis mínimos de preços aos produtos.

A partir da década de 30, o Estado acentuou a prática de promover políticas de estímulo à produção, baseadas em estratégias de desenvolvimento da coordenação entre os agentes. Tais estratégias visavam principalmente incentivar o aumento da qualidade por meio de subsídios à pesquisa técnica, influenciar a oferta de maneira a atingir preços adequados e estimular as vendas por meio de promoções e propagandas (Zylbersztajn et al., 1992).

Após o fim da $2^{a}$ Guerra Mundial, uma verdadeira revolução ocorreu no setor agrícola, impulsionado pela forte mecanização e pelo uso intensivo de capital, que reduziu drasticamente a quantidade de mão-de-obra empregada no setor e provocou a especialização das atividades. Com criação da Comunidade Econômica Européia (CEE), em 1957, o foco do país tornou-se o ganho de competitividade no interior da Comunidade. A posição geográfica estratégica permitiu à Holanda tornar-se o principal pólo de distribuição de mercadorias na Europa.

Particularmente, a Holanda beneficiou-se da ampliação da área do mercado consumidor, permitindo a expansão e o desenvolvimento do setor de FLV. Se, por um lado, a política comum da CEE incentivou a produção agrícola dos países membros, ao mesmo tempo prejudicou os ganhos de produtividade frente ao resto do mundo em razão do protecionismo excessivo de alguns países. Dentro de tal contexto, o papel do Estado holandês foi determinante no processo de ganho de eficiência, ao promover estímulos que garantissem a continuidade do desenvolvimento do setor, apesar das restrições impostas pela política comum da CEE. Particularmente, a adoção de padrões mínimos na agricultura foi inicialmente imposta pelo Estado, sendo a adesão obrigatória pelos produtores. A medida que o setor evoluiu, as regras públicas foram paulatinamente sendo 
substituídas por restrições privadas mais amplas com adesão voluntária dos produtores.

O setor de horticultura teve um crescimento elevado e contínuo de demanda até o inicio da década de 80, permitindo a estruturação de um sistema eficiente de produção em razão da forte atuação do Estado como promotor da eficiência coordenativa, ao monitorar e penalizar qualquer desvio das regras estabelecidas. Assim, o surgimento ocorreu de forma exógena na maioria das cadeias produtivas de FLV na Holanda, sendo que a reputação do Estado em punir os infratores teve papel decisivo para o estabelecimento de padrões e a redução do oportunismo dos agentes. Ao mesmo tempo, continuava em vigor o plano do Estado de concentrar elevados investimentos em pesquisas que favorecessem o aumento da eficiência produtiva no campo.

A partir da década de 80, o modelo adotado começou a mostrar sinais de enfraquecimento, em razão da saturação da demanda por alimentos na Europa, o crescimento da competição proveniente dos países do leste europeu e da redução da capacidade de investimento do Estado. O excesso de oferta de FLV, associado à modificação da demanda de produtos homogêneos para produtos diferenciados e refinados e à alteração das preferências dos consumidores, impulsionam as atuais modificações na estrutura produtiva do setor. Ao mesmo tempo, a presença do Estado vem diminuindo e modificando-se, de promotor de mudanças para simplesmente órgão regulador, cabendo ao setor privado preencher o espaço deixado.

Enquanto a presença do Estado restringe-se ao fornecimento de informações a respeito da certificação do produto e garantias de qualidade e segurança de alimento, o setor privado, especialmente o varejo moderno, preocupa-se com o estabelecimento de normas que permitam rastrear completamente todo o processo produtivo da cadeia de FLV. Assim, novas estruturas de governança são necessárias para coordenar as transações no setor. 


\subsubsection{ASPECTOS GERAIS}

Há aproximadamente 14.000 produtores de FLV na Holanda, localizados ao sul do país, próximos a Roterdã e Bélgica. A produção é fragmentada, sendo normalmente efetuada em pequenas fazendas familiares. O número de produtores vem declinando rapidamente nos últimos anos, tendo decrescido 20\% desde 1994 em razão dos baixos preços praticados e do aumento de escala das firmas que provocou a elevação do grau de concentração no setor.

A participação da cadeia de FLV corresponde a $42 \%$ da produção agrícola do país, sendo a produção de vegetais ao ar livre responsável pela maior área de produção da cadeia. O crescimento da produção de FLV ocorre continuamente no país, em decorrência da busca de antigos produtores por novas oportunidades na agricultura, migrando para o setor produtivo mais dinâmico na atualidade.

Há duas formas predominantes de produção de FLV na Holanda: a céu aberto e em estufas. A horticultura a céu aberto é a mais disseminada no país, em virtude do baixo investimento que o produtor necessita realizar para iniciar o plantio. Entretanto, tal modo de produção é inviável durante o rigoroso inverno da região, prejudicando o rendimento anual.

A horticultura baseada na utilização de estufas ocupa uma área de 10.000 hectares, representando somente $10 \%$ da área utilizada no setor pelo país. 0 cultivo de vegetais sob estufas ocupa $42 \%$ da área total, representando $7,5 \%$ do valor da produção do setor agrícola. Tomate (1.100 hectares), pimenta (1.000 hectares) e pepino ( 800 hectares) são os principais produtos plantados no sistema de estufas. Somente uma pequena parcela da produção de frutas ocorre sob estufas (1\%). A produção de maçã (12.800 hectares) e pêra (6.000) são as duas principais culturas de frutas do país, sendo o cultivo realizado predominantemente sob céu aberto (99\%).

O cultivo e a produção sob estufas ocorrem continuamente durante todo o ano, permitindo um alto desempenho do sistema. Empresas familiares especializadas na produção de um único tipo de FLV representam a grande maioria dos agentes que utilizam infra-estrutura com tecnologia de ponta. $O$ cultivo 
ocorre sobre um substrato que contém todas as propriedades biologicamente desejáveis para a planta, dispensando o uso da terra. A especialização da produção permite o emprego da mecanização e a utilização de sistemas computadorizados para controlar a oferta de água, fertilização, temperatura, ventilação, umidade, concentração de dióxido de carbono no ar e insolação. Sensores ópticos são empregados em substituição ao olho humano no sistema automatizado de colheita, transporte, classificação e embalagem. O emprego da infra-estrutura tecnologicamente avançada permite a redução da quantidade de trabalhadores empregados nas estufas, além de promover o aumento da produção e da qualidade dos produtos obtidos e de gerar redução dos custos.

Ao mesmo tempo, a elevada quantidade de investimentos realizados em pesquisa na área agrícola no país ao longo das últimas décadas permite um excelente rendimento por hectare na agricultura e, em especial, na horticultura. Institutos de pesquisa conduzem diversos estudos sobre o cultivo de vegetais de alta qualidade, com o objetivo de aprimorar sabor, aparência, aspectos nutricionais e resistência a pragas. A atuação conjunta de especialistas e dos agentes envolvidos na atividade produtiva de FLV tem como objetivo final um contínuo processo de aperfeiçoamento da qualidade dos produtos, que permite a manutenção de altos níveis de desempenho.

A Holanda é um dos maiores exportadores europeus de produtos agrícolas. Na tabela 1, observa-se que o setor de alimentos tem um papel de destaque na pauta de exportações do país.

TABELA 1: COMPOSIÇÃO DAS EXPORTAÇÕES (\%)

\begin{tabular}{|l|c|}
\hline \multicolumn{1}{|c|}{ SETOR } & $\mathbf{2 0 0 0}$ \\
\hline Máquinas e Equipamentos de Transporte & 30,20 \\
\hline Química & 23,50 \\
\hline Alimentos & 18,00 \\
\hline Bens Manufaturados & 12,20 \\
\hline Outros Produtos & 10,70 \\
\hline Matéria Prima & 5,40 \\
\hline
\end{tabular}

Fonte: Statistics Netherlands (CBS) 
O país mantém uma balança comercial favorável para produtos agrícolas e alimentos, possuindo uma elevada participação no mercado mundial de flores, batatas e vegetais. A União Européia constitui o principal mercado consumidor, respondendo por $78,5 \%$ do total das exportações holandesas do setor, onde se destaca a Alemanha (50\%) como principal parceiro comercial ${ }^{25}$.

A balança comercial tem sido negativa para frutas in natura e positiva para vegetais, sendo positiva no geral para a cadeia de FLV. O país importa grande quantidade de frutas tropicais, como laranja, banana e pêssego, originários principalmente da Espanha (19\%), Bélgica e Luxemburgo (17\%) e Chile (10\%).

O consumidor holandês gasta cerca de US\$ 3,7 bilhões por ano com produtos de horticultura (plantas ornamentais e alimentos), sendo a cadeia de FLV responsável por $66 \%$ do total. A despesa com FLV representava $17 \%$ da despesa total com alimentação em 1996, e vem progressivamente crescendo ao longo dos anos em decorrência do recente aumento da preocupação da população com a adoção de uma alimentação saudável.

$O$ fato dos FLV serem produtos altamente perecíveis faz com que 0 consumidor holandês prefira adquirir os produtos diariamente em pequenas quantidades. O principal canal de distribuição é o varejo moderno, responsável pela comercialização de $73 \%$ da produção do país.

A importância da feira livre é relativamente pequena na Holanda, em decorrência da qualidade inferior e da falta de padronização dos produtos vendidos em tais equipamentos varejistas, embora apresentem preços ligeiramente inferiores. O holandês é um consumidor sofisticado que prefere adquirir produtos com qualidade superior, optando pelo pagamento de preço prêmio por produtos com marcas comerciais e/ou selos de garantia que possuam reputação no setor.

\footnotetext{
${ }^{25}$ Statistics Netherlands (CBS): dados referentes a 2001.
} 


\subsubsection{ORGANIZAÇÃO DA CADEIA DE FLV}

A figura 6 ilustra a estrutura da cadeia produtiva holandesa de FLV. A comercialização dos produtos ocorre principalmente via leilões, embora recentemente alguns produtores tenham passado a vender diretamente aos atacadistas, varejistas e firmas processadoras. O surgimento de uniões de produtores e organizações comerciais constitui uma estratégia recente na Holanda, que vem crescendo continuamente no país. As uniões de produtores são compostas por grupos de produtores de produtos específicos, que têm afetado a distribuição do poder de mercado, tradicionalmente sob domínio dos leilões, afetando negativamente a participação dos leilões na comercialização dos FLV. Entretanto, apesar o crescimento nos últimos anos, ainda representa uma pequena parcela na comercialização de FLV do pais $(2 \%)$.

FIGURA 6: ESTRUTURA DA CADEIA HOLANDESA DE FLV

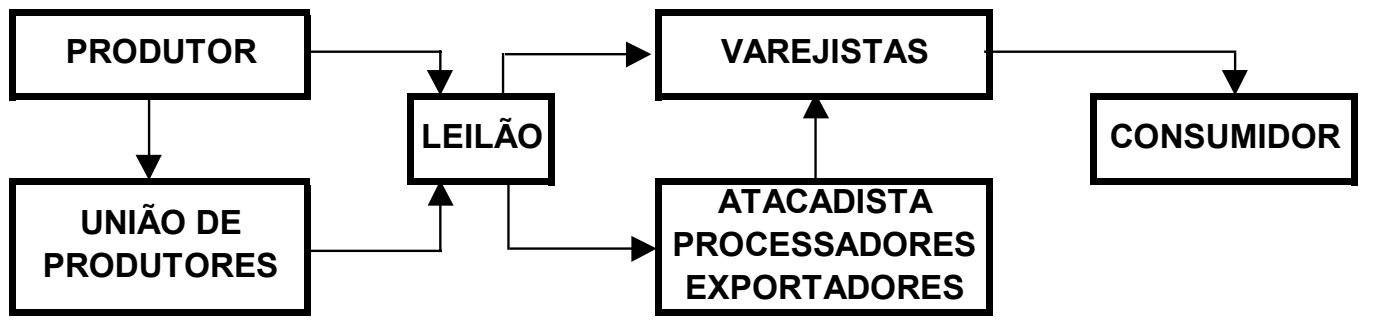

FONTE: ELABORAÇÃO DO AUTOR

O leilão possui uma estrutura física onde os agentes negociam os produtos, e localiza-se geograficamente nas proximidades das áreas produtoras devido à especificidade temporal dos produtos frescos. Tais estruturas constituem cooperativas pertencentes aos produtores, cuja função principal é permitir a atuação conjunta de produtores filiados.

Segundo Zylbersztajn et al. (1992) o leilão constitui uma forma eficiente de reduzir a diferença de poder entre vendedores e ofertantes. A motivação do produtor para vender no leilão é fortalecer seu poder de barganha frente aos grupos organizados de atacadistas e varejistas. É permitido ao leilão vender lotes 
originários de diferentes produtores como um lote único desde que formem um conjunto homogêneo do produto. A maior parte dos produtos comercializados no leilão utiliza o sistema do relógio ("clock"). O ponteiro move-se do preço mais elevado para o mais baixo. Ao pressionar o botão o lote é comprado pelo preço indicado no relógio. Caso o preço indicado no relógio atinja um preço mínimo prédeterminado, o lote é simplesmente retirado da venda e destruído, pagando-se ao produtor o preço mínimo. Todos os produtores membros do leilão contribuem financeiramente para o pagamento do preço mínimo.

O leilão Zon é o mais tradicional da Holanda, sendo especializado na venda de vegetais. $\mathrm{Na}$ estrutura do Zon, cada produtor está associado a uma organização de comercialização do produto que, por sua vez, é um membro efetivo do leilão. $O$ leilão Zon possui 28 organizações para frutas e vegetais, 1 para flores e 1 para cogumelos.

O maior leilão holandês, o Greenery ${ }^{26}$, recentemente aboliu o emprego do relógio para a comercialização dos produtos. A nova estratégia não foi bem aceita principalmente pelos produtores. Como conseqüência, o número de produtores vendendo no leilão Zon aumentou, devido à insatisfação com relação ao novo método empregado pelo Greenery. Por motivo idêntico, o número de pequenos leilões tradicionais na Holanda vem crescendo aceleradamente. Os pequenos leilões consistem de pequenas cooperativas onde o produtor é um membro direto, não necessitando associar-se a nenhuma organização.

Os atacadistas adquirem os produtos nos leilões, comercializando-os com supermercados, pequenas firmas domésticas, países e firmas estrangeiras. Recentemente, alguns atacadistas iniciaram o estabelecimento de contratos diretamente com os produtores, incentivados pela iniciativa da Greenery, constituindo, porém, uma estratégia pouco disseminada. A concentração horizontal no setor atacadista é pequena, sendo que as 33 maiores empresas são responsáveis por $40 \%$ da participação mercado. Por outro lado, a concentração entre as firmas exportadoras é maior, sendo 10 empresas responsáveis por $50 \%$ da participação de mercado.

\footnotetext{
${ }^{26}$ Organização comercial que opera no mercado independentemente dos produtores
} 
A distribuição ao consumidor de FLV utiliza diversos canais na Holanda. O comércio varejista tradicional inclui feiras livres, vendedores de rua e mercearias. Os supermercados consistem no principal canal de distribuição, com $73 \%$ do total das vendas de FLV, sendo $61 \%$ das vendas de frutas. Seguindo a tendência mundial nos últimos anos, a participação dos supermercados na venda de FLV tem continuamente aumentado na Holanda.

A estrutura de mercado no setor varejista é altamente concentrada, estando $73 \%$ da participação de mercado em poder das cinco maiores redes de supermercados, conforme apresentado na tabela 2. Apesar da concentração do setor, a alta competição entre os varejistas modernos tem provocado a redução das margens.

TABELA 2: PARTICIPAÇAO DE MERCADO

\begin{tabular}{|l|c|}
\hline \multicolumn{1}{|c|}{ Varejista } & $(\mathbf{\%})$ \\
\hline Albert Heijn & 28 \\
\hline Vendex Food & 13 \\
\hline Unigro/ De Boer & 13 \\
\hline Schuitema & 11 \\
\hline Audi & 8 \\
\hline
\end{tabular}

Fonte: Ftdistributie (1998)

O principal grupo, Royal Ahold, opera seis cadeias de lojas varejistas na Holanda, que incluem os grupos Albert Heijn (supermercado), Gall\&Gall (comercialização de bebidas finas) e Etos (venda de produtos de beleza), presente em 23 países e detentor de uma rede de 7.000 pontos de venda no mundo. 0 objetivo principal do grupo Ahold é tornar-se líder do segmento em todos países nos quais possua operações, utilizando uma estratégia agressiva de aquisições e alianças. Para atingir tal objetivo, a empresa desenvolve a estratégia de construir uma rede mundial varejista que proporcionaria economias de escala, troca de informações sobre práticas utilizadas e benchmarking. 


\subsubsection{SISTEMAS DE PADRÕES E ESTRATÉGIAS DE QUALIDADE}

A regulação EC2200, promulgada em 1996 no Common Agricultural Policy, determina as características qualitativas dos FLV comercializados na União Européia (UE). A regulação fornece requerimentos mínimos para os atributos de pesquisa, utilizando critérios claros e precisos para diferenciar os produtos em classes de qualidade. Além da regulação da qualidade, existem também regras para certificação, embalagens e ambientais, constituindo um conjunto complexo de requerimentos.

A necessidade de formação de lotes homogêneos para comercialização dos FLV em leilões estimulou o estabelecimento de padrões e classificações pelos produtores filiados às cooperativas. A evolução do sistema apresenta marcos importantes, como o estabelecimento do sistema de preços mínimos em 1948 e do sistema de padronização em 1968. O surgimento precoce de padrões na Holanda permitiu que a cadeia de FLV se organizasse de maneira eficiente.

O sistema de preços mínimos permite aos produtores não terem que vender os produtos com renda marginal negativa, atuando como um monopolista e reduzindo o poder de barganha dos compradores. A definição do preço mínimo pelo leilão leva em consideração os preços praticados na Europa para o produto, independendo da classificação, visando atrair agentes de diversos países. Em geral, somente os produtos de menor qualidade acionam o sistema.

Com o estabelecimento dos padrões, os produtores puderam definir qual tipo de produto desejavam vender e, ao mesmo tempo, classificar e embalar o produto na própria propriedade conforme as normas estabelecidas pela cooperativa, adicionando valor ao produto. $\mathrm{O}$ incentivo para o produtor agir de maneira oportunista é reduzido, uma vez que a reputação do produtor está diretamente associada ao produto vendido no leilão. A proximidade locacional entre os compradores no interior do leilão permite o surgimento de uma rede de comunicação de baixo custo extremamente eficiente. $O$ comportamento oportunista do produtor terá conseqüências imediatas no valor de seu produto negociado, implicando em elevadas perdas econômicas. Ao mesmo tempo, o novo 
processo de classificação apresenta custo elevado para o produtor, que fica impedido de negociar no leilão durante tal período.

Assim, os padrões estabelecidos e utilizados pelos produtores têm grande credibilidade e aceitabilidade no mercado consumidor. O nome do leilão funciona como marca comercial frente aos consumidores, tratando-se de um mecanismo de sinalização dos produtos transacionados. O efeito adverso da perda de reputação fornece o controle necessário para a manutenção dos níveis de qualidade na cadeia de FLV holandesa. Ao mesmo tempo, a redução dos custos de monitoramento dos contratos garante o aumento da eficiência do leilão.

As estratégias de qualidade da indústria hortifrutícola baseiam-se em regulamentações mandatórias, editadas por agências multinacionais, União Européia e agências governamentais nacionais. Ao mesmo tempo, permite-se que as firmas participem de estratégias de qualidade voluntárias, tais como o sistema de segurança de qualidade integrado para todos os agentes da cadeia (IKZ); rótulos privados ou marcas comerciais para firmas individuais ou grupos (horizontal ou vertical) de firmas; ISO; sistema de controle ambiental para produtores (MBT) e código de higiene para FLV não processados (HACCP).

Paralelamente, a UE possui determinadas medidas para apoiar os produtores agrícolas. A oferta é regulada por meio de subsídios às exportações e tarifas de importação, mas não utiliza o sistema de quotas. No entanto, nenhuma medida vem sendo adotada para impedir a redução de preços causada pelo excesso de oferta na horticultura. O governo holandês não permite nenhuma política de distorção comercial entre os países da UE, não podendo promover uma política que favoreça os agricultores do país.

Na Holanda, há incentivos à inovação na agricultura por meio de subsídios que visam melhorar o desempenho da atividade. Há a provisão legal de recursos criados pelo governo para auxiliar a horticultura, como, por exemplo, restituição de taxa de energia, verba para melhoria da infra-estrutura das estufas, provisão para o uso de gás como fonte de energia na horticultura, entre outros. Outros tipos de subsídios visam melhorar a qualidade do produto e a eficiência do processo 
produtivo, além da criação de novos produtos e o desenvolvimento de estratégias ambientais.

A UE fornece regras públicas de qualidade, cujo cumprimento é obrigatório somente para os produtos mais comercializados na região, como tomate e pepino. Paralelamente, o governo holandês emite regras para os produtos secundários sem a participação da UE. As inspeções de qualidade nos leilões, supermercados e lojas são realizadas por uma instituição pública (KCB) que possui regras próprias. A previsão é que, futuramente, tais regras serão incluídas no European Union Quality Control Regulation e na Dutch Agricultural Quality Law.

Os leilões possuem um sistema próprio de qualidade que adiciona regras extras às exigidas pela KCB. Os produtos oferecidos para venda devem seguir um critério de qualidade que inclui tamanho, peso e cor. Critério idêntico deve ser adotado em todos os leilões para os mesmos produtos. De forma geral, são três classes de qualidade, onde somente os produtos incluídos na terceira classe não podem ser comercializados como produtos frescos. As regras dos leilões são voluntárias e vistas como um sinal de garantia de qualidade dos produtos. Cada leilão fornece um certificado de qualidade ao lote aprovado na inspeção.

De forma complementar às regras privadas dos leilões e às regras públicas, existem outras formas de monitoramento da qualidade dos FLV na Holanda. O sistema IKZ estabelece uma lista de regras de qualidade a serem adotadas na cadeia produtiva. Envolve regras de qualidade para os produtos e os processos empregados (classificação, limpeza e distribuição) ao longo da cadeia. A cadeia produtiva agrícola que recebe o certificado de produção IKZ tem permissão para colocar um selo de qualidade no produto para diferenciá-lo dos concorrentes. $\mathrm{O}$ certificado ISO constitui o sistema de regras de qualidade mais restritivo. Organizações voluntariamente adotam as normas ISO por acreditar que a reputação do certificado tem um forte impacto no comportamento do consumidor.

O Consumentbond consiste na principal organização de consumidores holandeses, controlando a qualidade do produto por meio de inspeções aleatórias e pelo registro de reclamações dos consumidores sobre produtos e lojas. A rede 
de transmissão de informações do Consumentbond apresenta grande poder de inibição ao comportamento oportunista dos agentes.

Em suma, o conjunto de regras e sistemas adotados, privados e/ou públicos, apresenta elevado grau de complementaridade e cria um ambiente institucional favorável à redução dos custos de transação ex-post, permitindo, assim, elevados ganhos de renda pelos agentes em virtude do aumento da eficiência da coordenação vertical na cadeia. Ao mesmo tempo, tal conjunto fornece credibilidade aos agentes e reduz a quantidade de informação imperfeita ao longo da cadeia, ao transmitir de forma mais eficiente os atributos de crença e pesquisa presentes nos FLV. A contínua manutenção do padrão de qualidade permite o surgimento do efeito reputação associada ao agente e ao conjunto de regras e sistemas, constituindo um importante mecanismo informal de coerção ao comportamento oportunista.

\subsubsection{NOVAS ESTRATÉGIAS NA CADEIA DE FLV}

Em função da saturação do crescimento da oferta de FLV na Holanda e UE e do aumento do poder do varejo moderno, vem ocorrendo a elevação da demanda por padrões de qualidade diferenciados, que possuem atributos mais estritos dos que adotados normalmente nos leilões. Tal fato tem provocado o aparecimento de novas estratégias na cadeia produtiva de FLV que visam atender à nova demanda dos consumidores e, ao mesmo tempo, reduzir o poder de barganha das cooperativas. Trata-se de uma tentativa de redistribuição da renda entre os agentes, promovida especialmente pelo varejo moderno.

Ao mesmo tempo, a diminuição da capacidade dos órgãos públicos em definir e controlar atributos cada vez mais complexos, incentiva o crescimento da participação privada na definição e implementação de novos padrões e classificações de qualidade. A preocupação atual do Estado holandês consiste em promover um ambiente institucional favorável para a realização das transações por meio da utilização de instrumentos efetivos de controle e punição. Especificamente para o setor de frutas e vegetais, o Estado holandês em conjunto 
com a OECD, busca difundir a utilização de certificados reconhecidos internacionalmente no interior da cadeia produtiva, melhorar as condições de transporte dos produtos e incentivar o desenvolvimento da padronização de embalagens e rótulos. O presente estudo apresentará as principais estratégias adotadas na Holanda.

\subsubsection{THE GREENERY}

A fusão de 12 leilões em 1996 deu origem ao The Joined Horticulture Auctions (VTN), um novo agente na cadeia produtiva de FLV com grande poder de barganha. Os membros do VTN são, além de produtores, proprietários de uma parte do capital dos leilões unificados. O VTN constitui o único acionista da The Greenery, empresa que vem empreendendo um processo de inovação do setor ao criar novos produtos e conceitos, com o objetivo de adicionar valor ao produto e promover ações que visam proteger o meio ambiente. Trata-se de uma empresa de distribuição, vendas e marketing que atua no setor de produtos frescos em toda UE.

A nova estratégia da empresa eliminou a utilização do relógio como forma de venda dos produtos, adotando, em substituição, contratos formais entre produtores e compradores. A organização negocia diretamente com grandes empresas varejistas européias e produtores, tentando modificar o foco de orientação do produto para o mercado consumidor. Ao mesmo tempo, a The Greenery vem promovendo um progressivo processo de integração vertical, adquirindo grandes firmas distribuidoras no interior da cadeia de FLV. Entretanto, a nova estratégia ainda não foi bem aceita pelos produtores mais tradicionais que sentiram diretamente a redução de seu poder de barganha frente aos varejistas e atacadistas.

A The Greenery atua ativamente no desenvolvimento de sistemas de certificação e controle de qualidade para os produtores associados, visando harmonizar seus padrões e classificações com os desenvolvidos no varejo moderno. Todos os produtos ofertados pela empresa são produzidos segundo 
especificações definidas em sistemas privados de controle de qualidade, como o Greenery Quality System (GZS). O certificado privado GZS somente é emitido para os produtores que incorporem recomendações ambientais, de higiene, segurança de alimentos e de condições de trabalho na produção dos FLV. O GZS permite aos produtores certificados atender facilmente a outros sistemas de controle de qualidade, como o EUREPGAP do setor varejista moderno.

Outra estratégia desenvolvida pela The Greenery consiste na criação do selo próprio para os produtos frescos orgânicos (GO). Atualmente, um de grupo de 25 produtos é oferecido nos diversos equipamentos varejistas com o selo GO.

\subsubsection{VAREJO MODERNO: INCORPORAÇÃO DE ATRIBUTOS DE CRENÇA}

Em 2000, vários supermercados europeus desenvolveram um sistema próprio de controle de qualidade para a cultivação de FLV, denominado EUREPGAP. Trata-se de uma estratégia coletiva que envolve a diferenciação do produto. O EUREPGAP estabelece especificações ambientais, higiênicas, de segurança alimentar e de condições de trabalho, utilizando sistemas de informação que permitem rastrear totalmente o processo produtivo. Atualmente, os supermercados associados requerem que todos os FLV adquiridos e comercializados atendam as recomendações fornecidas pelo sistema.

Outra estratégia inovadora no setor é desenvolvida pelo grupo Ahold. A estratégia adotada consiste na diferenciação do produto com base em preocupações com as questões ambientais. Todas as empresas associadas ao grupo ao redor do mundo desenvolvem projetos relacionados à origem dos produtos, buscando atender à crescente preocupação dos consumidores com a segurança e a qualidade dos alimentos. A estratégia pretende associar ao grupo (marca e reputação) a imagem positiva conseguida frente ao consumidor em razão da preocupação com questões ambientais. Dentro de tal contexto, a empresa incentiva projetos que buscam a utilização eficiente de energia, a criação de sistemas de refrigeração não poluentes e a reciclagem de embalagens. 
Uma observação importante consiste na preocupação de integrar os sistemas de controle de qualidade entre os agentes da cadeia. Assim, o GZS e o EUREPGAP apresentam elevado grau de complementaridade dos atributos de crença especificados, não sendo, portanto sistemas concorrentes. Tal fato, aumenta a credibilidade do selo e a quantidade de informação disponível ao consumidor.

\subsubsection{UNIÃO DE PRODUTORES}

O surgimento de uniões de produtores é recente na Holanda, não sendo ainda bastante disseminada no país. Entretanto, a estratégia tem afetado a distribuição de poder no interior da cadeia de FLV.

Um grupo de produtores descontente, membros de leilões, passou a fornecer os produtos produzidos às uniões, desrespeitando a regra de fornecimento exclusivo dos leilões. Tais produtores reclamam do rígido sistema de controle de qualidade dos leilões, que dificulta a produção de FLV de primeira classe, ou seja, a classificação mais elevada. Entretanto, a qualidade exigida para produtos de primeira classe constitui parte da estratégia de gerenciamento da reputação do leilão frente ao consumidor interno e externo. Qualquer redução dos parâmetros de qualidade terá uma forte repercussão negativa sobre a reputação do leilão. O conflito entre as partes tem sido potencializado pela ameaça de exclusão do produtor do leilão.

\subsubsection{VAREJO MODERNO: DESENVOLVIMENTO DE MARCAS PRÓPRIAS}

Os grandes grupos varejistas modernos têm desenvolvido marcas próprias para os produtos frescos, buscando diferenciar seus produtos dos competidores e conquistar a confiança dos consumidores. A adoção da estratégia de marca necessita do estabelecimento de acordos recíprocos de longo prazo com os fornecedores, visando garantir a qualidade dos produtos e o abastecimento 
regular. Tais acordos incluem especialmente atributos de pesquisa e experiência, mas já começam a aparecer contratos com especificações referentes a atributos de crença.

A estratégia favorece principalmente as pequenas empresas que não possuem marca própria conhecida pelos consumidores. A colocação da marca do varejo moderno permite que tais empresas tenham um volume maior de vendas, em razão de o consumidor associar a credibilidade da loja ao produto vendido sob sua marca própria. Por outro lado, o varejo moderno precisa estabelecer critérios rígidos na seleção dos fornecedores, pois a perda de reputação junto ao consumidor afeta diretamente a comercialização dos produtos vendidos em todos os departamentos da loja.

\subsection{A CADEIA BRASILEIRA DE FLV}

A cadeia produtiva de FLV é uma das menos desenvolvidas no Brasil, apresentando ausência de padrões mínimos de referência efetivos e assimetrias excessivas no sistema de informação. A infra-estrutura de apoio encontra-se em uma precária, não contanto com número suficiente de câmaras frias $\mathrm{e}$ apresentando todas as estruturas logísticas (estradas, armazéns, entre outros) mal cuidadas e obsoletas. Conseqüentemente, a incerteza, tanto endógena quanto exógena, é elevada e o mercado físico continua sendo necessário para coordenar o fluxo da produção e comercialização.

Os contratos informais são comuns no mercado de produtos frescos, sendo baseados em vantagens recíprocas entre as partes e disciplinados pela confiança, reputação e sanções comerciais (troca de fornecedor), e não por intermédio de procedimentos legais. Todavia, os arranjos informais tendem a ser substituídos por arranjos formais no longo prazo com o aumento da freqüência das transações e a elevação da especificidade dos produtos em razão do aumento das exigências de qualidade.

A falta de informação a respeito do mercado hortifrutícola é o principal problema enfrentado pelos agentes da cadeia produtiva brasileira de FLV. O 
sistema atual de comercialização, baseado nas Centrais Estaduais de Abastecimento (CEASAs), não tem capacidade de transmitir eficientemente informações sobre preços, condições de mercado, consumo e qualidade. Observa-se que o setor público não conseguiu definir padrões e classificações na cadeia produtiva de FLV, prejudicando o desenvolvimento do setor. Apesar do padrão público existir, o formato atual não consegue atender às necessidades dos agentes privados da cadeia e, na maioria dos casos, dificulta a realização da transação.

Complementando o cenário hortifrutícola brasileiro, as estruturas logística e administrativa são obsoletas e ineficientes, não permitindo a concretização de ganhos de escala, gerando altos custos logísticos que enfraquecem todos os elos da cadeia produtiva.

\subsubsection{ANTECEDENTES}

As crises de abastecimento no país iniciaram-se no final do século XIX. Segundo Belik (2000), a dificuldade de abastecimento referia-se principalmente a problemas de escassez de oferta, que, naquele momento, dependia excessivamente das importações de alimentos. Os reflexos da crise mundial de 1870 reduziram drasticamente os preços dos produtos primários diminuindo a quantidade de divisas existentes no país, afetando diretamente a importação de alimentos. Naquele instante, a solução encontrada pelo Estado consistiu na redução dos impostos de importação e incentivos à criação de pequenas lavouras, visando elevar a oferta de alimentos nas áreas rurais no longo prazo. Entretanto, houve falta de políticas direcionadas ao suprimento de alimentos nas áreas urbanas que começavam a surgir no país.

No início do século $X X$, sucessivas crises de abastecimento assolaram o país em razão das duas guerras mundiais e da crise de 1929. Em 1917, uma nova crise de abastecimento ocorreu em virtude do crescimento das exportações de alimentos aos países em guerra, provocando novamente a redução da oferta interna de alimentos. A instituição do Comissariado de Alimentação Pública em 
1918 tinha como objetivo regular preços e estoques de alimentos de primeira necessidade (Belik, 2000).

No período entre guerras sucessivamente se alternaram momentos de relativa tranqüilidade e eclosão de crises profundas de abastecimento no país. Somente a partir do governo Vargas, a ação do Estado passou a efetivamente instituir incentivos à produção, controle de preços e medidas punitivas aos responsáveis pelos problemas de abastecimento (Belik, 2000). As crises subseqüentes, provocadas pelo inicio da segunda guerra mundial e pela instabilidade macroeconômica do governo JK, influenciaram negativamente a produção e oferta de alimentos. Até o momento, o país ainda dependia da importação de produtos primários para abastecer as camadas sociais menos favorecidas, não possuindo nenhuma política adequada de desenvolvimento para o setor agrícola.

Somente a partir da década 60, o intervencionismo do Estado deixa de ser normativo para tomar a forma de ações diretas sobre a organização e a regulação de um sistema de abastecimento, interferindo sobre toda a cadeia produtiva (produtor, atacado e varejo). A nova estratégia baseava-se na criação de entrepostos de abastecimento públicos nos principais núcleos urbanos do país. Assim, durante a década de 70 , o governo brasileiro iniciou o processo de implantação de centrais de abastecimentos (CEASA), na tentativa de gerar uma infra-estrutura pública onde ocorresse a comercialização privada de produtos primários no interior de um ambiente competitivo, visando aumentar a transparência das transações e facilitar o acesso de pequenos produtores ao mercado de produtos frescos.

O sistema público de distribuição de alimentos perecíveis teria três funções básicas: física, econômica e informativa. A função física seria desempenhada por entrepostos ou plataformas de distribuição, envolvendo transporte, manipulação, estocagem, reorganização e expedição do produto. O principal resultado da racionalização do sistema logístico consistia em gerar economias de escala multiproduto. A função econômica e financeira tinha o papel de favorecer a negociação de preços, condições de troca e pagamento. Por último, a função de 
informação permitia organizar otimamente os fluxos de produtos por meio da criação de mecanismo que geravam a transmissão da informação entre os agentes. É importante ressaltar que a criação do sistema público tinha também como objetivo primário aumentar a quantidade de informação disponível aos agentes do mercado.

Na década 90, com processo de modernização e abertura da economia brasileira, a reavaliação dos objetivos e instrumentos de atuação do Estado moderno envolvia a privatização tanto da infra-estrutura pública quanto dos serviços onde o Estado mantinha o direito de propriedade sobre a infra-estrutura. A privatização das centrais de abastecimento enquadra-se no processo de redefinição do papel do Estado. Tornou-se uma tendência mundial a substituição do sistema público promulgador por estruturas de coordenação vertical privada, onde o Estado passa a ter somente um papel regulador. O Brasil deve seguir a mesma direção futuramente, apesar das atuais dificuldades registradas na tentativa de reestruturação do setor.

Com o fim dos problemas de abastecimento o país começou a preocuparse com a elevação da qualidade dos produtos ofertados. Somente no final da década de 90 começaram a surgir as primeiras tentativas de estabelecimento de normas de classificação, ainda de forma incipiente, no Estado de São Paulo.

O sucesso do objetivo de aproximar oferta e demanda de produtos hortifrutigranjeiros foi alcançado com a construção das centrais de abastecimento pelo Estado brasileiro. Entretanto, o padrão concorrencial previsto pelo Estado não foi factível, na medida em que surgiram rendas não competitivas advindas da formação de grupos de interesse no interior das centrais de abastecimento. A intervenção do Estado na área de abastecimento teve sucesso na redução da dependência da importação de alimentos, porém fracassou no estabelecimento de padrões mínimos de qualidade dos produtos comercializados na cadeia produtiva de FLV.

Os preços dos produtos hortícolas ainda se formam no interior das CEASAs sem diferenciação por qualidade e influenciados diretamente pelas estratégias dos atacadistas permissionários. Como conseqüência, tais atacadistas detêm 
informação privilegiada sobre o mercado, sendo contrários a qualquer mudança no atual sistema de comercialização que possa afetar o seu poder de barganha. Desta forma, o antigo sistema tem sido incapaz de atender à demanda crescente do varejo moderno e do setor de fast-food por produtos com padrões de referência mínimos quanto à qualidade dos FLV.

Apesar do surgimento de plataformas privadas, tanto o varejo tradicional quanto o moderno ainda são abastecidos direta ou indiretamente, total ou parcialmente, pelos CEASAs, não conseguindo ofertar aos consumidores produtos diferenciados e diversificados. Até os dias atuais, o sistema público permanece predominante na comercialização de FLV no Brasil. As transações envolvendo FLV dependem fortemente do mercado físico spot e das CEASAs. Em tal contexto, a CEAGESP (Companhia de Entrepostos e Armazéns Gerais do Estado de São Paulo) é o mais importante centro de abastecimento de supermercados e feiras livres. A CEAGESP tem papel preponderante no sistema público de distribuição de produtos primários no Brasil, apesar do constante declínio, tanto do volume total quanto do valor total comercializado $(11 \%$ e $21 \%$ desde 1995 , respectivamente) englobando uma ampla estrutura física (lojas, armazéns, silos, etc.) e uma estrutura de coordenação do abastecimento de produtos perecíveis. Diversas companhias atacadistas privadas compõem e atuam como permissionários nos centros de distribuição geridos pelo Estado.

O surgimento de formas alternativas de comercialização, como contratos formais e informais entre varejistas e atacadistas; contratos entre varejistas/atacadistas e produtores; e integração vertical, somado à construção de centros privados de distribuição, vem diminuindo gradativamente a quantidade de produtos enviados à CEAGESP.

Ao mesmo tempo, algumas companhias privadas construíram infraestrutura própria nas proximidades dos centros de distribuição públicos, buscando melhorar o controle sobre a quantidade e qualidade dos produtos enviados para comercialização nas CEASAs. O principal objetivo das empresas privadas é aumentar a transparência dos negócios, reduzindo a assimetria informacional entre os agentes da cadeia. 
Por último, a legislação atual e os grupos interessados na manutenção da atual estrutura de distribuição pública impedem o estabelecimento de padrões efetivos e o surgimento de uma estrutura mais moderna e eficiente. A falta de definição de sistemas de classificação e padrões de qualidade efetivos permite a transferência do excedente do produtor para os intermediários que atuam nas centrais públicas. A percepção de Williamson (1991) de que muitas estruturas de governança trazem no seu desenho os elementos de ineficiência associados à geração e apropriação de rendas por grupos de interesse, confirmam-se no caso da cadeia brasileira de FLV.

\subsubsection{ASPECTOS GERAIS}

O Brasil é o terceiro maior produtor de FLV, ficando atrás somente da China e da Índia no cenário internacional. O país exporta principalmente frutas tropicais e importa maçãs, pêras, uvas e ameixas. Apesar da elevada produção, o país não apresenta posição relevante no comércio mundial, tendo em vista que a maioria dos produtos é consumida internamente.

No cenário internacional, apenas algumas nações possuem elevado nível de consumo per capita de FLV na dieta habitual. Há raras exceções à baixa média de consumo familiar de FLV no mundo. Por exemplo, uma família holandesa, em média, consome 186 quilos de FLV por ano, enquanto o consumo de uma família brasileira não passa de 86 quilos por ano. A situação brasileira é semelhante à maioria das nações. O consumo brasileiro de FLV, apesar de ser bem inferior ao consumo holandês, é considerado comparativamente elevado no cenário mundial.

Em termos de consumo per capita, o Brasil apresenta somente alto consumo de legumes, como indicado por Pekkarinev (1975). O consumo de FLV não é distribuído uniformemente na população brasileira. Segundo dados do Instituto Nacional de Alimentação e Nutrição (INAN) para 1996, somente 44\% da população brasileira consome frutas e $58 \%$ legumes e vegetais. 
GRÁFICO 2: DISTRIBUIÇÃO GEOGRÁFICA DO CONSUMO DE FLV (\%)

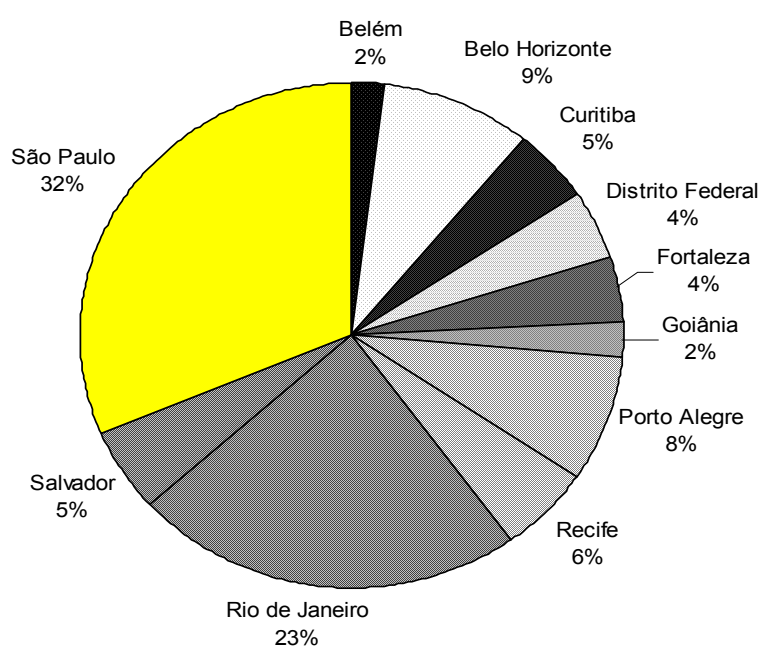

Fonte: Pesquisa de Orçamento Familiar (POF) - IBGE - 1996

Similarmente, a distribuição geográfica do consumo de FLV também é irregular no país. O gráfico 2 indica que 64\% consumo ocorre em São Paulo, Rio de Janeiro e Belo Horizonte, conferindo alto grau de concentração à região sudeste do Brasil.

O elevado consumo em São Paulo (32\%) foi um dos fatores decisivos para a observação de redução da participação da despesa com FLV no país. $\mathrm{Na}$ totalidade das regiões pesquisadas pela Pesquisa de Orçamento Familiar (POFIBGE) ocorreu uma redução de $9,16 \%$ para $8,61 \%$ na participação das despesas com FLV no interior do conjunto de despesas familiares (Tabela 3).

TABEA 3: DESPESACOMFLVNADESPESAFAMLARTOTAL (\%)

\begin{tabular}{|c|c|c|c|c|c|c|c|c|c|c|}
\hline POF & Belém & $\begin{array}{c}\text { Belo } \\
\text { Horizonte }\end{array}$ & Guritiba & Fortaleza & $\begin{array}{c}\text { Porto } \\
\text { Alegre }\end{array}$ & Recife & $\begin{array}{c}\text { Rio de } \\
\text { Janeiro }\end{array}$ & Salvador & São Paulo & Total \\
\hline $\mathbf{1 9 8 6}$ & 6,90 & 8,35 & 8,31 & 6,21 & 7,60 & 7,75 & 9,15 & 6,76 & 10,48 & 9,16 \\
\hline $\mathbf{1 9 9 6}$ & 7,84 & 9,64 & 7,34 & 7,71 & 8,48 & 9,82 & 9,11 & 8,53 & 8,09 & 8,61 \\
\hline Variação & 0,94 & 1,30 & $(0,97)$ & 1,49 & 0,88 & 2,07 & $(0,03)$ & 1,77 & $(2,39)$ & $(0,55)$ \\
\hline
\end{tabular}

Fonte: Pesquisa de Orçamento Familar - IBGE - 1986 e 1996 
Os centros urbanos na região Nordeste e Belo Horizonte apresentaram acréscimo, enquanto São Paulo, Rio de Janeiro e Curitiba obtiveram redução da participação da despesa com FLV na despesa familiar. O aumento das despesas com alimentação fora do domicílio nos grandes centros urbanos de São Paulo, Rio de Janeiro e Porto Alegre, explica a diminuição do consumo de FLV no país como um todo (Tabela 4).

TABELA 4: DESPESA COM ALIMENTAÇÄO FOR A DO DOMICILIO (\%)

\begin{tabular}{|c|c|c|c|c|c|c|c|c|c|c|}
\hline POF & Belém & $\begin{array}{c}\text { Belo } \\
\text { Horizonte }\end{array}$ & Curitiba & Fortaleza & $\begin{array}{c}\text { Porto } \\
\text { Alegre }\end{array}$ & Recife & $\begin{array}{c}\text { Rio de } \\
\text { Janeiro }\end{array}$ & Salvador & São Paulo & Total \\
\hline $\mathbf{1 9 8 6}$ & 22.80 & 25.40 & 21.99 & 25.61 & 21.76 & 24.28 & 26.06 & 28.76 & 22.96 & 24.49 \\
\hline $\mathbf{1 9 9 6}$ & 19.01 & 27.06 & 21.85 & 23.95 & 24.73 & 19.63 & 28.64 & 22.95 & 25.55 & 25.35 \\
\hline Variação & $(3.79)$ & 1.66 & $(0.13)$ & $(1.66)$ & 2.96 & $(4.65)$ & 2.59 & $(5.81)$ & 2.59 & 0.85 \\
\hline
\end{tabular}

Fonte: Pesquisa de Orçamento Familar - IBGE - 1986 e 1996

A variação dos preços no atacado e no varejo apresenta grande variância em razão do efeito da sazonalidade, diminuindo aproximadamente $60 \%$ durante o período de safra.

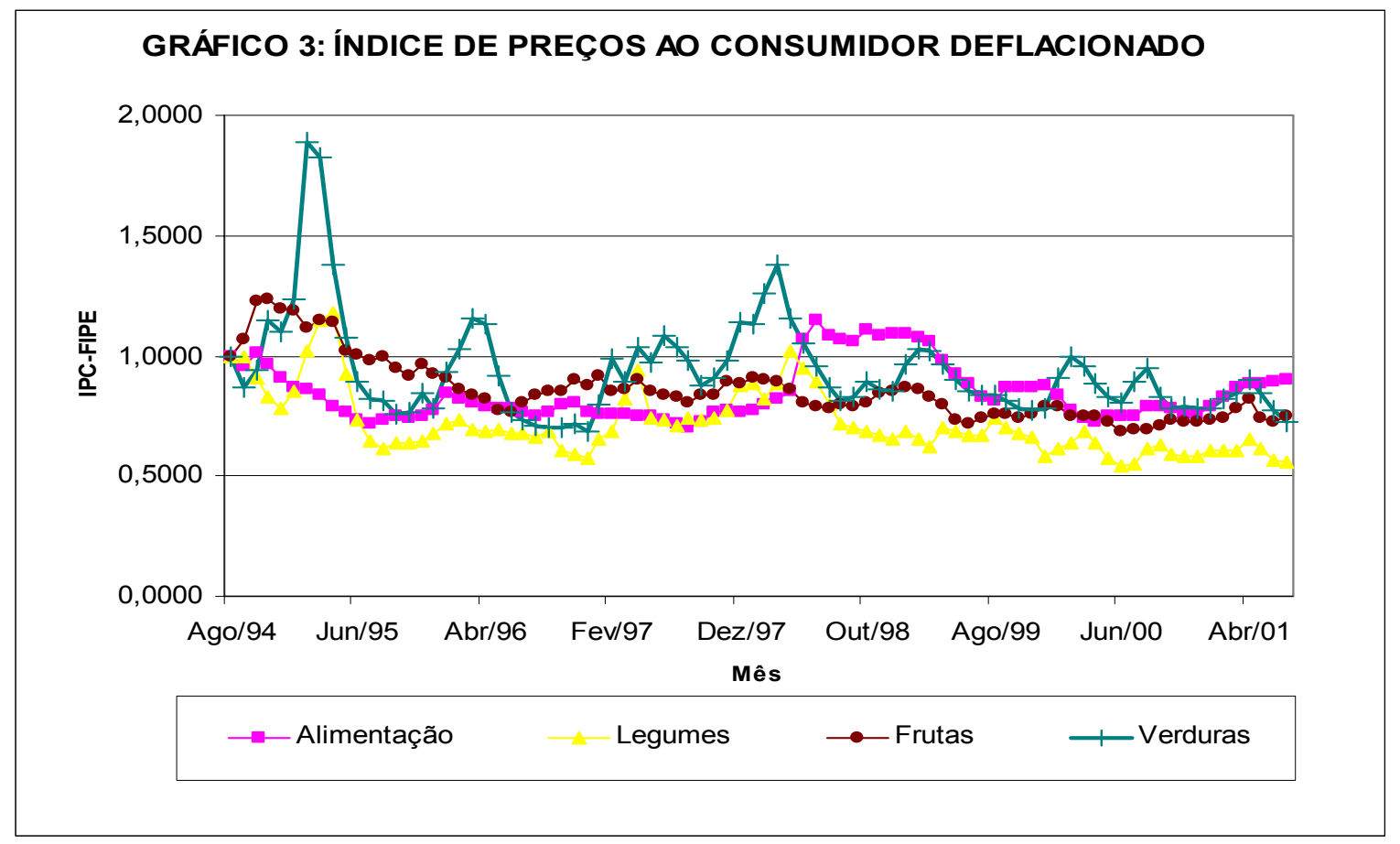

Fonte: FIPE-USP, 2001 
O gráfico 3 mostra o comportamento do IPC-FIPE ${ }^{27}$ deflacionado para frutas, legumes, verduras e alimentação entre agosto/1994 e julho/2001. Observase que a variação do preço das verduras apresenta maior amplitude quando comparada aos preços de frutas e legumes. Tal fato deve-se a redução na produção durante o período de chuvas. A falta de utilização de tecnologia moderna nas culturas de verduras dificulta a manutenção de níveis estáveis de produção ao longo do ano. A elevada variância dos preços provoca o aumento dos custos de transação em razão do aumento da incerteza endógena.

Outra informação importante do gráfico 3 refere-se a tendência declinante no IPC-FIPE dos FLVs ao longo do período. O crescimento da oferta vem progressivamente provocando a redução dos preços dos gêneros alimentícios. No período em questão, o IPC-FIPE indica a redução em termos reais de 9,99\% para os alimentos em geral; $43,99 \%$ para legumes; $24,92 \%$ para frutas e $27,42 \%$ para verduras. A redução nos preços deve-se ao aumento da oferta dos produtos em decorrência da melhoria das técnicas empregadas no campo, aumento da mecanização e utilização intensiva de fertilizantes.

\subsubsection{ORGANIZAÇÃO DO MERCADO BRASILEIRO DE FLV}

Sempre houve no Brasil a preponderância da comercialização de FLV em feira livres. Somente recentemente começou-se a observar a queda da participação das feiras em razão do aumento de interesse do varejo moderno na comercialização de produtos frescos. O aumento da presença da mulher no mercado de trabalho modificou os hábitos comportamentais dos consumidores em razão da diminuição do tempo médio disponível para aquisição e preparação das refeições em casa.

A tabela 5 mostra que a feira livre vem continuamente perdendo participação de mercado para os supermercados e quitandas em São Paulo,

\footnotetext{
${ }^{27}$ Índice de Preços ao Consumidor da Fundação Instituto de Pesquisas Econômicas.
} 
enquanto no Rio de Janeiro e Belo Horizonte, os postos alternativos de venda $(\mathrm{PAV})^{28}$ têm aumentado a participação na distribuição varejista de FLV.

TABELA 5: VARIAÇÃO DO LOCAL DE AQUISIÇÃO DE FLV ENTRE 1986 E 1996 (\%)

\begin{tabular}{|l|l|c|c|c|c|c|c|c|c|c|}
\hline $\begin{array}{c}\text { Equipamento } \\
\text { Varejista }\end{array}$ & Belém & $\begin{array}{c}\text { Belo } \\
\text { Horizonte }\end{array}$ & Curitiba & Fortaleza & $\begin{array}{c}\text { Porto } \\
\text { Alegre }\end{array}$ & Recife & $\begin{array}{c}\text { Rio de } \\
\text { Janeiro }\end{array}$ & Salvador & São Paulo & Total \\
\hline Mercearia & $(6.31)$ & $(8.41)$ & $(3.17)$ & 16.80 & $(2.19)$ & 5.45 & 1.90 & 1.72 & $(0.50)$ & 0.57 \\
\hline Quitanda & 0.35 & $(0.10)$ & 1.29 & $(3.33)$ & $(0.10)$ & 0.54 & $(0.11)$ & 3.14 & 13.05 & 1.99 \\
\hline Feira Livre & $(1.70)$ & $(7.34)$ & $(9.31)$ & $(1.95)$ & $(2.75)$ & $(9.34)$ & $(17.89)$ & $(23.52)$ & $(22.22)$ & $(13.08)$ \\
\hline Supermercado & 7.78 & $(4.97)$ & 16.26 & $(2.13)$ & 4.61 & 7.88 & $(9.33)$ & 14.40 & 5.23 & 4.93 \\
\hline PAV & $(2.81)$ & 21.08 & $(5.29)$ & $(6.55)$ & $(1.31)$ & $(1.97)$ & 25.92 & 1.88 & 4.21 & 5.17 \\
\hline Outros & 2.79 & 0.04 & 0.16 & $(2.83)$ & 1.64 & $(2.56)$ & $(0.73)$ & 2.32 & 0.42 & 0.44 \\
\hline
\end{tabular}

Fonte: Pesquisa de Orçamento Familar - IBGE - 1986 e 1996

Embora em São Paulo as feiras livres ainda ocupem a posição de liderança no setor, os supermercados (especialmente pequenos e médios) têm aumentado sua participação na distribuição de FLV. Para o total das áreas metropolitanas analisadas pela POF, observa-se a redução da importância da feira livre como local de aquisição de FLV em razão do surgimento dos PAV e do crescimento da participação dos supermercados.

O setor varejista moderno vem paulatinamente tornando-se o elo mais importante da cadeia de distribuição de alimentos perecíveis. Os supermercados constituem o principal canal de distribuição de FLV na maioria das áreas metropolitanas brasileiras, com exceção de São Paulo, Belém e Belo Horizonte, onde as feiras livres e PAV constituem os principais pontos de venda de FLV (Gráfico 4).

Apesar da grande aceitação do público, as vendas realizadas nos PAV apresentam diversos problemas, como a baixa qualidade dos produtos, baixa margem de lucro e elevadas perdas físicas, ocasionadas pela constante manipulação pelo consumidor e pela falta de padronização e classificação dos produtos. Segundo Souza et al. (1998) espera-se o crescimento dos PAV e a

\footnotetext{
${ }^{28}$ Segundo Farina e Machado (2000) os PAV compreendem três tipos diferentes de equipamentos varejistas: varejões, sacolões e comboios. Os varejões são grupos de várias lojas especializadas na venda de frutas e legumes que se reúnem em locais específicos para comercializar os produtos a preços inferiores. Já os comboios são minivarejões com uma única pequena loja para cada tipo de produto. Por último, os sacolões são lojas onde as frutas e legumes são vendidos por quilo a um
} 
formação de amplas redes de distribuição, com instalações em vários bairros de diferentes classes sociais. O sistema atual de aquisição dos produtos utiliza um grupo de compradores que percorrem as zonas de produção, utilizando como preço de referência para negociação a cotação das CEASAs com desconto médio de $20 \%$.

A partir da década de 90, o setor supermercadista brasileiro apresentou uma tendência de redução do número de empresas e a entrada de diversos grupos internacionais ${ }^{29}$ no país por meio de fusões e aquisições. A tabela 6 fornece informações gerais fornecidas pela Associação Brasileira de Supermercados (ABRAS) para o setor supermercadista brasileiro.

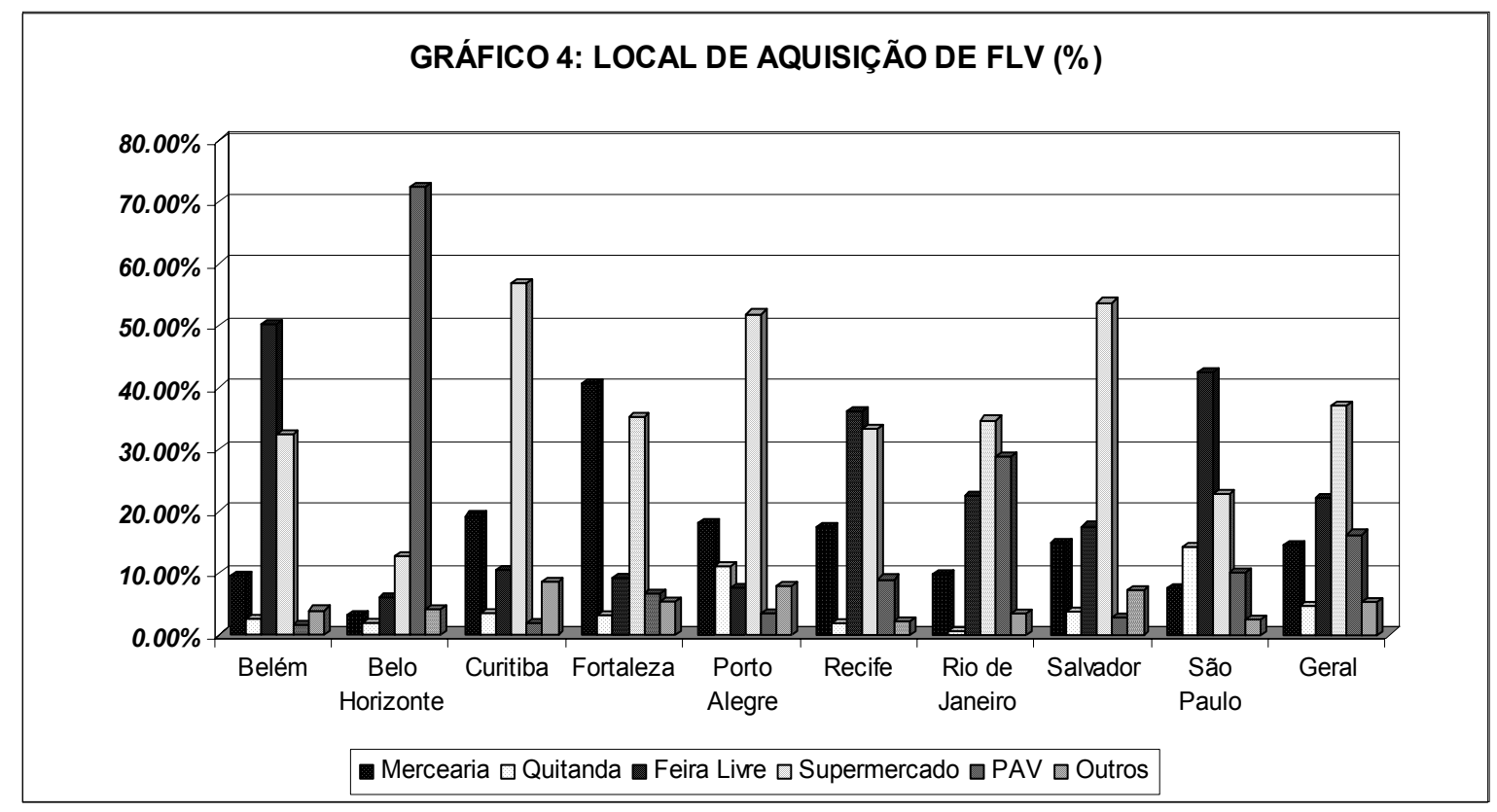

Fonte: Pesquisa de Orçamento Familiar (POF) - IBGE - 1996

Segundo a ABRAS, o faturamento do setor cresceu 21,80\% entre 1998 e $2000^{30}$. O crescimento do número de lojas e da mão-de-obra empregada, $18,95 \%$ e 5,23\% respectivamente, indicam a tendência de expansão do setor no Brasil. Os supermercados tratam-se dos principais responsáveis pelo aumento da

preço único, baseado na média dos preços do atacado. Os sacolões foram criados como um programa social que visava incentivar o consumo de FLV das populações de baixa renda.

${ }^{29}$ Wal-Mart, Royal Ahold e Carrefour. 
concorrência entre os equipamentos varejistas, uma vez que podem oferecer preços mais baixos ao operar com margem negativa para os produtos hortícolas, com intuito de atrair consumidores oriundos de outros equipamentos varejistas.

TABELA 6 SETOR SUPERMERCADISTA

\begin{tabular}{|l|r|r|r|}
\hline \multicolumn{1}{|c|}{ Item } & \multicolumn{1}{|c|}{1998} & \multicolumn{1}{c|}{1999} & \multicolumn{1}{c|}{$\mathbf{2 0 0 0}$} \\
\hline Faturamento Anual (R\$ bilhões & 55,50 & 60,10 & 67,60 \\
\hline Participação PIB (\%) & 6,10 & 6,00 & 6,20 \\
\hline Número de Lojas (milhares) & 51,50 & 55,31 & 61,26 \\
\hline Empregos Diretos (milhares) & 666,75 & 670,08 & 701,62 \\
\hline
\end{tabular}

Fonte ABRAS

A participação de mercado das cinco maiores empresas aumentou de $37 \%$ em 1995 para 40,8\% em 2000 do faturamento total do setor. Tal resultado indica um grau de concentração médio com a existência de um número grande de empresas de porte médio e pequeno. A tabela 7 mostra as cinco empresas com maior faturamento em 2000. Como o processo de fusões e aquisições ainda não se encerrou no país, espera-se um aumento da concentração nos próximos anos. O crescimento da competição no setor tem provocado a alteração da estratégia adotada pelo varejo moderno com o cliente e o fornecedor.

As novas estratégias baseadas na diferenciação do produto pela qualidade visam conquistar novos clientes e buscar soluções que permitam melhorar a coordenação do setor frente às transformações do ambiente institucional.

TABELA 7: PARTICIPAÇÃO DO SETOR (2000)

\begin{tabular}{|l|c|}
\hline \multicolumn{1}{|c|}{ Empresa } & $\mathbf{( \% )}$ \\
\hline Cia. Brasileira de Distribuição & 14.1 \\
\hline Carrefour & 14.1 \\
\hline Bompreço & 4.5 \\
\hline Sonae & 4.4 \\
\hline Sendas & 3.7 \\
\hline
\end{tabular}

Fonte: ABRAS

\footnotetext{
${ }^{30}$ Informações referentes ao último dia do ano.
} 


\subsubsection{SISTEMAS DE PADRÕES E ESTRATÉGIAS DE QUALIDADE}

O desenvolvimento da cadeia produtiva brasileira de FLV apresenta dois marcos delimitadores: a criação das CEASAs no final da década de 60 e o processo de abertura comercial da economia brasileira na década de 90. Entre o período do final do século XIX até a década de 60 o Estado brasileiro defrontavase com um grave problema de escassez de oferta, motivada pela completa falta de estrutura produtiva para a produção de alimentos básicos para a população. Todas as intervenções do Estado tinham um tratamento policial da questão de abastecimento, tendo somente caráter normativo. Durante este período não houve uma grande preocupação com a padronização e classificação dos produtos, que se restringiam ao estabelecimento de padrões mínimos para os atributos de pesquisa. Entretanto, a questão da escassez de alimentos permanecia como principal foco de atenção do Estado, que não se preocupou em criar mecanismos eficientes de coerção e fiscalização das características dos produtos.

O segundo período, entre as décadas de 60 e 90, foi marcado pelo surgimento das centrais de abastecimento público. $O$ diagnóstico em tal momento indicava que o investimento privado para a correção das falhas do mercado de FLV seria sub-ótimo em virtude das economias de rede e externalidades. A criação de uma estrutura pública para promover a comercialização privada de produtos primários tinha como objetivo aumentar a competição no setor de FLV por meio da redução da quantidade de informação privada mantida pelos agentes. Novamente, a preocupação central do Estado referia-se somente a organização e regulação do sistema de abastecimento, deixando em segundo plano a criação de instrumentos de controle e coerção dos padrões mínimos de referência. Sob tal ponto de vista, a atuação do Estado para a resolução dos problemas de abastecimento teve êxito, mas, ao mesmo tempo, provocou grandes distorções na cadeia produtiva de FLV, como o surgimento de grupos de interesse no interior das centrais de abastecimento.

Somente a partir de meados da década de 90, iniciou-se uma mudança de orientação nas estratégias adotadas na cadeia de FLV. Com os problemas de 
abastecimento solucionados, o foco central de atenção tornou-se a criação de sistemas eficazes de classificação e padronização. Assim, no final da década de 90, de forma incipiente no Estado de São Paulo, começam a surgir as primeiras tentativas de estabelecimento de normas de classificação no setor de FLV, instituídas pelas Câmaras Setoriais de Frutas e Hortaliças da Secretária de Agricultura do Estado de São Paulo. Tal iniciativa compreende um conjunto de normas gerais que definem atributos de identidade, qualidade, acondicionamento, embalagem, rotulagem e apresentação dos produtos (Revista Frutas e Legumes, 2000).

O programa implementado possui adesão voluntária, sendo coordenado pelo Centro de Qualidade em Horticultura da CEAGESP (CQH). A iniciativa pioneira apresentou resultados positivos surpreendentes, como a grande aceitação entre os agentes. Segundo estimativas do $\mathrm{CQH}, 90 \%$ do volume comercializado de FLV no Estado de São Paulo já se beneficiam de alguma forma das normas de classificação. O sucesso da estratégia estimulou o surgimento de novas iniciativas em outros CEASAs (Belo Horizonte e Campinas), além de impulsionar a criação de mercados virtuais.

Paralelamente, o varejo moderno começou a adotar estratégias que restringem a aquisição de produtos aos fornecedores que não se enquadrem nos pré-requisitos mínimos de qualidade. A exigência de qualidade baseia-se atualmente somente nos atributos de pesquisa (preço, tamanho, cor, textura, manchas, etc.). A perspectiva de longo prazo é a incorporação de atributos de experiência (sabor, frescor, amadurecimento e aparência) e alguns atributos de crença (ausência de resíduos químicos e pesticidas e questões ambientais) entre os pré-requisitos exigidos pelo varejo moderno. O pagamento de preço prêmio por produtos dentro das especificações consiste na principal forma de incentivar os agentes a realizarem os investimentos necessários para atender os novos parâmetros de qualidade. Entretanto, o risco de quebra contratual tem-se mostrado elevado tanto para os fornecedores quanto para o varejo moderno, prejudicando a implementação do sistema. 
Segundo Souza et al. (1998), 60,9\% dos supermercados entrevistados indicam que o principal requisito exigido na seleção de seus fornecedores consiste na adoção a padrões e classificações que se enquadrem às suas necessidades. A assiduidade na entrega e a qualidade do produto consistem em outros itens importantes mencionados nas entrevistas. A preocupação com a garantia de entrega do produto no prazo determinado trata-se de uma variável de extrema relevância na negociação, pois a falta de assiduidade prejudica a imagem do varejo moderno frente ao consumidor.

A nova orientação da cadeia produtiva promove o surgimento de novas estratégias de coordenação específicas a cada transação. A próxima seção dedica-se a apresentar as principais estratégias dos agentes a partir de dados empíricos levantados em entrevistas com supermercados, atacadistas, produtores e órgãos governamentais.

\subsubsection{NOVAS ESTRATÉGIAS DE COORDENAÇÃO}

A partir do processo de desregulamentação, iniciado em 1990, e da estabilização monetária, em 1994, o consumidor urbano tornou-se mais exigente em relação aos quesitos preço e qualidade. Ao mesmo tempo, a liberalização do comércio, a Lei de Proteção ao Consumidor e a crescente conscientização do consumidor acerca de questões sobre saúde e nutrição ${ }^{31}$ têm aumentado a preocupação dos agentes da cadeia de FLV com relação à qualidade dos produtos transacionados. O novo perfil de preferências da população exige alterações nas estratégias adotadas pelos agentes junto aos consumidores. Segundo Souza et al. (1998), é preciso aumentar a diversificação dos produtos, criar novas formas de apresentação e preparo, buscando atingir um público diversificado. O aumento da oferta de produtos mais práticos, que reduzam 0 tempo de preparo, e de produtos resfriados e congelados, são exemplos típicos de estratégias que aumentam o valor agregado e acompanham a evolução do comportamento do consumidor. 
O estabelecimento de cadeias varejistas internacionais no Brasil aumentou após o início do Plano Real e estabeleceu um novo padrão de competição no setor varejista. Os grupos internacionais adotaram a estratégia de adquirir redes brasileiras de supermercados como forma de ingressar no setor, estimulando a modernização das companhias brasileiras. A competição mais acirrada tem reduzido as margens operacionais dos supermercados e o departamento de FLV tornou-se um fator de diferenciação e recuperação de margens. Assim, as maiores cadeias de supermercados vêm progressivamente adotando novas estratégias que enfatizam a venda de FLV.

Complementando o cenário, os novos hábitos comportamentais da população incentivaram o surgimento e a disseminação das redes de fast-food no país. O rápido crescimento do setor de fast-food, decorrente do surgimento de empresas nacionais e do ingresso de empresas internacionais no país, implementou novas perspectivas e ampliou as oportunidades existentes no interior da cadeia de FLV.

A adoção de padrões rígidos de controle de qualidade e o uso racional do espaço físico impuseram novas restrições às transações, aumentando a especificidade de ativo. A impossibilidade de recebimento e processamento (limpeza, corte e preparo) dos produtos frescos no espaço da loja e a necessidade de um cronograma rígido de abastecimento geraram a necessidade de uma nova estratégia própria ao setor. Assim, as características inerentes ao próprio negócio exigem a adoção de padrões rígidos de qualidade e o controle dos prazos de entrega. Em suma, o crescimento das redes de fast-food está aumentando a demanda por produtos semiprocessados, criando oportunidade para o surgimento de empresas especializadas no processamento dos produtos primários.

O gerenciamento da cadeia produtiva de FLV é extremamente complexo em razão da alta especificidade do ativo. A ausência de padrões mínimos aumenta o grau de incerteza das transações no Brasil, conforme discutido anteriormente (capítulo 4). Em suma, os novos padrões de competição exigem

\footnotetext{
${ }^{31}$ Sarti e Machado (2000).
} 
que novas estruturas de governança sejam adotadas pelos agentes da cadeia produtiva de FLV, conforme se discute a seguir.

\subsubsection{VAREJO MODERNO E PRODUTOR}

As entrevistas realizadas junto aos supermercados indicaram que a maioria já vem adquirindo FLV diretamente dos produtores, especialmente verduras. Segundo Souza et al. (1998), 67\% das grandes redes adquirem verduras diretamente do produtor e $14 \%$ adotam um sistema misto de compra. Os CEASAs ainda constituem a principal fonte fornecedora dos supermercados médios e pequenos, embora ambos já tenham estabelecido relações comerciais com os produtores.

Por outro lado, as empresas maiores vêm realizando integração parcial para trás, investindo em centros próprios de distribuição de FLV. Segundo varejistas entrevistados, a integração vertical parcial é uma forma de apoio à estratégia de qualidade empreendida pelo setor. Segundo Souza et al. (1998) quando o volume de compras está acima de 2000 toneladas/dia, o setor varejista moderno prefere organizar as compras de FLV em centrais de compras próprias. As grandes redes varejistas vêm investindo na construção de Centrais de Compras para o recebimento de produtos perecíveis, aumentando o abastecimento feito diretamente com produtor.

Segundo Green (1993), a plataforma de compras apresenta menor custo logístico, ao permitir a completa separação das atividades de carga e descarga, situação que não ocorre na estrutura atual dos CEASAs. A mecanização das operações e a informatização dos pedidos permitem a otimização da logística de transporte por meio da criação de rotas de entregas. Ao mesmo tempo, a redução do manuseio e o menor tempo gasto na montagem dos pedidos permitem que 0 produto entregue esteja mais fresco e pouco danificado, permitindo o aumento do preço prêmio obtido pelo produto de qualidade superior.

$O$ estabelecimento de acordos informais entre o varejo moderno e os produtores inclui uma lista de compromissos que envolvem credibilidade mútua 
entre as partes envolvidas na transação. Em geral, o varejista adianta parte do pagamento e fornece caixas limpas, recebendo entre troca a garantia do suprimento.

Observou-se que alguns varejistas utilizam o pagamento de preço prêmio como forma de incentivar o fornecimento de produtos com qualidade superior, sendo o mercado spot utilizado como referencial de preço. Entretanto, a falta de padrões mínimos de referência, não permite a correta mensuração do preço prêmio. Assim, a importância do mercado spot vem paulatinamente decrescendo, sendo substituído pela estratégia de negociação direta entre as partes, onde ficam estabelecidos, os padrões de qualidade desejados pelo varejo moderno e os preços prêmios exigidos pelo produtor. Entretanto, a ruptura contratual de ambas as partes ainda é freqüente. Somente com o estabelecimento da reputação por comportamento confiável haverá a redução dos custos de transação.

\subsubsection{VAREJO MODERNO E ATACADISTA}

Farina e Machado (2000) identificaram acordos formais e informais efetuados também entre supermercados e atacadistas, sendo que parte do risco da transação transferiu-se do primeiro para o último. A negociação de preços ainda se baseia no referencial fornecido pelo mercado spot (CEASA), como no caso anterior. Conseqüentemente, a maioria dos atacadistas prefere abastecer pequenos e médios supermercados e feiras livres, que ainda são altamente dependentes do mercado spot, buscando obter melhores resultados operacionais.

Uma estratégia adotada por grandes atacadistas com intuito de manter a fidelidade dos clientes trata-se da criação de uma associação informal para suprir as necessidades dos pequenos e médios supermercados. Tal empreendimento utiliza a infra-estrutura das centrais públicas como ponto logístico. Assim, o varejista garante uma provisão regular a preços competitivos e os membros da associação mantêm a participação de mercado.

Outra estratégia utiliza contratos formais entre atacadistas e supermercados. Um exemplo consiste nos contratos formais estabelecidos entre o 
grupo Pão de Açúcar e grandes empresas atacadistas de frutas. Os funcionários do atacadista ficam responsáveis pelo produto no interior das lojas, gerenciando o abastecimento e controlando o desperdício. O acordo permite ao supermercado elevar a qualidade do produto, reduzir custos com mão-de-obra e evitar o desperdício. Entretanto, tal estratégia não tem conseguido obter os resultados esperados pelo varejo moderno. Atualmente, os contratos formais encontram-se em fase de renegociação e, na maioria dos casos, ocorrendo o término da relação.

Por último, uma companhia atacadista utiliza uma estratégia baseada na integração a jusante. A empresa estabeleceu pontos de venda de varejo em São Paulo, Rio de Janeiro e Vitória, que são abastecidos diariamente por produtos adquiridos nas CEASAs e CEAGESP. A estratégia consiste em adquirir uma concessão de um box nos entrepostos públicos, que serve de ponto logístico para a aquisição dos produtos. Cada loja do varejo envia diariamente uma lista contendo os produtos desejados para o dia seguinte aos stands. Funcionários próprios adquirem os FLV nas centrais de abastecimento públicas, utilizando uma estratégia baseada no preço e em um padrão de qualidade pouco apurado que atenda à baixa exigência de qualidade do consumidor brasileiro. Após o processo de compra, os pedidos são montados em caminhões próprios no interior das centrais públicas e despachados para as lojas do varejo.

\subsubsection{INDÚSTRIA DE PROCESSAMENTO E PRODUTORES}

Segundo Kasper (1991), a tendência de crescimento das refeições fora do domicílio (Tabela 4) reduzirá o consumo de alimentos adquiridos nos supermercados, transformando as redes de fast-food e restaurantes em concorrentes diretos do setor varejista moderno.

O surgimento de empresas especializadas para atender a demanda específica do segmento por produtos processados (fresh-cuts) teve início no Brasil com a chegada das grandes redes de fast-food. A estratégia adotada consiste na realização de contratos formais com produtores que estabelecem padrões de qualidade e preços, assim como a exclusividade de fornecimento do produtor com 
a empresa. As exigências normalmente são mais rígidas que a prescrita na legislação brasileira, envolvendo principalmente especificações de atributos de pesquisa e crença.

A estratégia encontra forte resistência dos produtores tradicionais que se recusam a aceitar facilmente os novos padrões de qualidade. As quebras contratuais são freqüentes, pois os centros de abastecimento público (CEASAs e CEAGESP) ainda constituem uma boa alternativa para negociar os produtos, tanto para os produtores quanto para a indústria de processamento. No entanto, a vulnerabilidade da indústria é maior contra o comportamento oportunista dos produtores, em virtude do compromisso com estratégias de qualidade junto ao consumidor, uma vez que, os produtores podem comercializar os produtos sem qualquer nível de exigência de qualidade.

\subsubsection{AÇÕES DO ESTADO}

A criação de instrumentos e/ou instituições que permitam o controle e monitoramento da qualidade pelo Estado, objetiva estabelecimento de mecanismos que forneçam credibilidade às estratégias privadas. Algumas ações que devem ser tomadas pelo Estado incluem provimento de um ambiente institucional adequado para os agentes privados atuarem, garantir a aplicação das regras e monitorar o cumprimento de normas legais, cuidar da saúde e da segurança da população e impedir a ação oportunista dos agentes.

Dessa forma, o Estado deve exercer o papel de agente regulador, auxiliando o setor privado a implantar padrões e sistemas de classificação e monitorar e aplicar penalidades contra os infratores. Sob tal ótica, o Governo de São Paulo criou em 2002 a Agência da Defesa Agropecuária, cujo objetivo principal será controlar e fiscalizar a produção agrícola e pecuária do Estado de São Paulo. A criação de dois selos de qualidade é o mecanismo utilizado para garantir a qualidade aos produtos. A obtenção do selo está condicionada a realização de uma detalhada análise da atividade agrícola desenvolvida ao longo da cadeia produtiva, incluindo inclusive a avaliação de atributos de crença, como 
as condições do solo e da água. A Secretaria de Agricultura e Abastecimento realiza o credenciamento dos produtores agrícolas e agroindustriais, além de fixar normas e padrões mínimos de qualidade. Todos os participantes passam a utilizar um selo que possui os dizeres: "Produto de São Paulo" (Lazzarotto, 2001).

Outra ação observada, trata-se da criação de fóruns que contam com a participação de agentes privados e órgãos públicos do setor de FLV, promovidos pela Secretaria de Agricultura e Abastecimento do Estado de São Paulo. Assim, as Câmaras Setoriais são compostas por entidades representativas dos diversos segmentos da cadeia produtiva, tendo como objetivo apoiar a concepção, a formulação e a execução de políticas públicas voltadas ao fortalecimento e elevação da competitividade do setor. Alguns resultados expressivos foram alcançados na Câmara Setorial de Frutas, como o estabelecimento de normas de classificação, o uso de embalagens adequadas e o desenvolvimento rótulos que permitem a identificação de pêssegos, goiabas e nectarinas.

A sistemática para fixar normas técnicas de produtos de origem agrícola, pecuária e agroindustrial, baseia-se na certificação de produtos e credenciamento de produtores. As normas adotadas apresentam adesão voluntária por parte dos agentes. A necessidade de utilização de uma linguagem comum para as transações, incentivou a expansão do programa para todo país. Desta forma, o Programa Brasileiro de Melhoria dos Padrões Comerciais e de Embalagens de Hortigranjeiros trata-se de uma estratégia nacional que visa o estabelecimento de sistemas de classificação e padrões. Rapidamente, o programa permitiu o estabelecimento de normas de classificação para o maracujá azedo em 2000. A obediência à norma pelos agentes na cadeia produtiva garante homogeneidade do lote, a caracterização física e a qualidade do produto.

As ações empreendidas pelo Estado constituem-se instrumentos que fornecem transparência à comercialização de FLV, possibilitando a adoção de métodos modernos de comercialização, escolha de nichos para o produto, maior rentabilidade para o produtor e produtos com qualidade superior ao consumidor. Entretanto, o Estado ainda precisa desenvolver uma forte reputação como agente regulador efetivo, situação que ainda não ocorreu no Brasil. 


\subsection{ASPECTOS CONCLUSIVOS}

Em linhas gerais, a cadeia produtiva holandesa de FLV encontra-se mais desenvolvida que a brasileira. Na Holanda, a fase de implementação de classificações e padrões ocorreu algumas décadas atrás. Ao mesmo tempo, a infra-estrutura de distribuição está completa, permitindo uma logística eficiente durante percurso percorrido da fazenda ao consumidor final. Por último, o ambiente institucional possui instrumentos eficientes de controle, fornecendo credibilidade aos padrões adotados, e o uso intensivo de sistemas de informação permite maior transparência às transações. A reputação dos agentes da cadeia constitui uma forte barreira contra o comportamento oportunista, uma vez que sua deterioração provoca a perda do fluxo futuro de renda e dos investimentos específicos realizados pelos agentes para atender as normas. O papel do Estado, ao longo dos anos, foi essencial para a melhora da coordenação vertical e da qualidade dos produtos na cadeia produtiva, ao realizar elevados investimentos em pesquisa e extensão e infra-estrutura, além de criar um aparato institucional eficiente para sustentar as transações.

Comparativamente, a cadeia brasileira de FLV encontra-se em um estágio anterior ao holandês. No Brasil, o processo de implementação de padrões e classificações iniciou-se recentemente e tem encontrado resistência de alguns agentes da cadeia produtiva. A infra-estrutura de apoio é precária, não contanto com número suficiente de câmaras frias e apresentando todas as estruturas logísticas (estradas, armazéns, entre outros) mal cuidadas e obsoletas. O efeito reputação dos agentes atuou no sentido contrário no caso brasileiro, elevando o custo de transação em virtude da necessidade de elevadas salvaguardas contratuais e na construção de dispendiosos sistemas de monitoramento pelos agentes privados em virtude da falta de confiança entre as partes. O papel do

Estado, ao longo dos anos, limitou-se a resolver os problemas de abastecimento, não criando um ambiente institucional que permitisse monitorar a conformidade com os padrões mínimos de atributos de pesquisa do setor. 
A principal explicação para a diferença no estágio de desenvolvimento das duas cadeias produtivas de FLV consiste nas dificuldades e necessidades históricas diferentes de cada nação, no período entre o final do século XIX e os dias atuais. Enquanto o Estado brasileiro defrontava-se com um grave problema de escassez de oferta no final século XIX, motivada pela completa falta de estrutura produtiva para a produção de alimentos básicos para a população, o Estado holandês apresenta-se parcialmente organizado. Assim, as estratégias adotadas pelo Estado no Brasil visavam somente solucionar o problema de abastecimento interno, enquanto que na Holanda, ao final da década de 60, o mercado de alimentos encontrava-se saturado, incentivando o aparecimento precoce de estratégias que visavam reduzir custos e melhorar o desempenho ao longo da cadeia produtiva.

A preocupação do Estado brasileiro ao longo do último século sempre foi centrada na questão de abastecimento da população de produtos primários, nunca se preocupando com o estabelecimento de padrões e a adoção de estratégias de qualidade. Se por um lado, a intervenção do Estado na área de abastecimento conseguiu reduzir a dependência do país das importações de alimentos, por outro lado, falhou no estabelecimento de padrões mínimos de qualidade dos produtos transacionados. Apesar da existência dos padrões, o Estado nunca conseguiu controlar e monitorar de maneira eficaz a sua adoção. Somente na última década com a resolução quase completa dos problemas de abastecimento de produtos primários, começou-se a discutir questões relativas às estratégias de qualidade, classificações e padronização.

Um segundo aspecto diferenciador importante, relacionado indiretamente com o fator histórico, consiste no papel do Estado na implementação de padrões. O Estado holandês teve uma participação ativa ao criar um ambiente institucional favorável ao desenvolvimento de padrões no setor, incentivando a criação de centros de pesquisa agrícola e de um sistema público regulador eficaz. Por outro lado, o Estado brasileiro tem participado timidamente do processo iniciado na década de 90. O momento histórico atual, no qual prega-se $\circ$ não intervencionismo do Estado no setor produtivo, explica tal comportamento no 
Brasil, enquanto que a orientação na Holanda no período pós-guerra incentivava o intervencionismo.

Um terceiro aspecto refere-se ao agente da cadeia produtiva que busca promover a padronização. No caso holandês, as cooperativas de produtores foram responsáveis pela distinção dos produtos em diferentes classes, que permitiu ao produtor visualizar com clareza os atributos de pesquisa necessários para obter o nível mais elevado de classificação $e$, conseqüentemente, melhor preço. A evolução natural das normas desde o pós-guerra acrescentou aspectos do processo de produção e, recentemente, atributos de crença associados a questões ambientais. No Brasil, o varejo moderno consiste no principal agente promotor da mudança. As novas estratégias adotadas utilizam como mecanismo para melhorar a coordenação das transações na cadeia produtiva de FLV a criação de padrões privados próprios.

Por último, o efeito reputação teve um papel decisivo, ao fornecer credibilidade aos agentes implementadores dos padrões e classificações no caso holandês. O esforço para preservação da reputação da cooperativa de produtores frente aos demais agentes teve o papel de inibir o comportamento oportunista ao estabelecer punições e sanções críveis. Da mesma forma, o Estado holandês apresentava mecanismos críveis de controle e monitoramento que permitiam a rápida aplicação da lei, fornecendo credibilidade ao sistema por meio da reputação por punir severamente quem não cumprir as regras. Paralelamente, a falta da capacidade de punir dos agentes pelo Estado brasileiro criou um efeito reputação inverso do caso holandês, que estimula o aparecimento do comportamento oportunista por falta de reputação de tornar crível uma ameaça de sanção.

Atualmente, as duas cadeias produtivas encontram-se em fase de transformação decorrente da rápida internacionalização dos mercados, do desenvolvimento de novas tecnologias de informação e da otimização da logística de transporte. O processo caracteriza-se por alterações significativas na base produtiva, aumentando a interdependência entre os segmentos produtivos e elevando a competitividade. Além disso, a organização da cadeia produtiva de FLV vem se alterando continuamente nos últimos anos, em razão de modificações 
na composição da demanda final, da elevação do potencial de oferta e do crescimento da importância das grandes cadeias varejistas modernas. Tais fatores estão induzindo os agentes a procurarem novas formas de organização, tratandose de um processo dinâmico que envolve a redistribuição da renda entre os agentes da cadeia.

Ao longo do capítulo foi mostrado que a capacidade adaptativa do ambiente institucional de cada país, frente às mudanças do padrão competitivo foi um fator de diferenciação da eficiência coordenativa da cadeia produtiva no passado. Assim, somente com a criação de instrumentos e/ou instituições que forneçam credibilidade e facilitem a propagação da informação à cadeia produtiva brasileira de FLV conseguirá atingir um nível elevado de eficiência no futuro. O processo de construção da reputação de tais instrumentos e/ou instituições permitirá a redução dos custos de transação, proporcionando a aumento da lucratividade do setor em razão da maior eficiência coordenativa entre os agentes. 


\section{CONCLUSÃO}

A cadeia produtiva de frutas, legumes e verduras frescos (FLV) vem sofrendo um rápido processo de transformação do padrão de competição centrado nas empresas individuais para a coordenação da cadeia produtiva. A busca do melhor desempenho ocorre por meio da cooperação mais estreita entre agentes visando principalmente elevar a qualidade do produto comercializado. A tese descreveu e explicou os mecanismos de coordenação vertical observados no setor utilizando a Teoria da Economia dos Custos de Transação (ECT).

$O$ crescimento da quantidade de atributos relevantes exige um novo processo de coordenação entre os segmentos da cadeia produtiva, mais complexo do que o baseado simplesmente no sistema de preços. As estratégias desenvolvidas pelo varejo moderno combinam mecanismos de mercado e contratos (formas híbridas), cujo mix permite a transferência de parte do risco das transações a outros agentes e garante uma posição central e dominante do varejo moderno na cadeia produtiva. $O$ instrumental teórico da ECT permitiu focalizar o problema de desenho de contratos capazes de motivar a atuação do agente privado e, ao mesmo tempo, manter os direitos de monitoramento e controle da atividade nas mãos do Estado.

A tese apresentou uma visualização global do processo de mudança do ambiente institucional ao longo dos capítulos 3 e 4 . No capítulo 3 realizou-se um detalhamento cuidadoso dos diversos aspectos dos atributos das transações envolvendo FLV. Foram descritas as dificuldades enfrentadas pelo varejo moderno para enfrentar as mudanças do ambiente competitivo, concluindo-se que a padronização trata-se de uma forma de resolver o problema que permite a redução dos custos de transação ao reduzir quantidade de informação imperfeita no setor. No capítulo 4, destacou-se a importância da padronização na coordenação vertical da cadeia produtiva, dos mecanismos que fornecem credibilidade ao padrão e das formas de transmissão de informação. Somente com o bom funcionamento, simultaneamente, dos mecanismos de credibilidade e sinalização, o processo de padronização empreendido pelo varejo moderno será 
bem sucedido. A falta de um deles fará qualquer tentativa de introdução de padrões privados no setor fracasse em função da elevada complementaridade dos dois mecanismos. O desenvolvimento da confiança mútua entre os agentes por meio do efeito reputação tem um papel fundamental na sustentação das estratégias. O efeito reputação consiste na amálgama de todo o processo.

Dentro deste contexto, o varejo moderno tem papel de destaque na promulgação de estratégias de diferenciação de produto que buscam reduzir os custos de transação envolvidos no fornecimento regular e constante de FLV de alta qualidade. Dentro da lógica do varejo moderno de buscar alterar o padrão de comercialização vigente, a implementação de estratégias que visam agregar qualidade e valor aos FLV tem como desafios alcançar a coordenação de todos os agentes da cadeia produtiva, criar um sistema eficiente de incentivos, reduzir o comportamento oportunista dos outros agentes e estimular o aparecimento de instituições públicas e privadas de controle. A coordenação escolhida pelo varejo moderno pode basear-se no sistema de preços, quando o produto transacionado tem baixa especificidade de ativo e ofertado por vários agentes. Caso contrário, a coordenação eficiente pode exigir a elaboração de contratos onde ficam prédefinidos instrumentos de incentivo e controle da transação.

A construção da reputação com fornecedores e consumidores por meio do estabelecimento relações comerciais de longo prazo trata-se de um elemento importante para o sucesso de tais estratégias. Barkema e Drabenstott (1996) indicam a predominância de relações de longo prazo baseadas em contratos, em substituição ao sistema tradicional de preços.

O conjunto dos capítulos 3 e 4 fornece uma visão bem detalhada da dificuldade de todo o processo consistindo na principal contribuição da tese, uma vez que há falta de trabalhos que associem todos os conceitos apresentados e discutidos para a cadeia de FLV. Em geral, os estudos concentram-se na descrição de somente um determinado aspecto (certificação, sinal de qualidade, marca comercial e reputação) da cadeia produtiva, pecando ao não mostrar a complementaridade e a interação entre eles. 
O presente estudo também identificou uma tendência de redução da participação do setor público na promulgação de sistemas de classificação e padronização em decorrência do surgimento espontâneo de sistemas privados de adesão voluntária, alinhando-se com os resultados encontrados por Belik, Santos e Green (2001) e Trienekens e Beulens (2000). Entretanto, a presença do Estado como órgão regulador ainda permanece importante conforme mostrado no último capítulo.

No capítulo 5 , realiza-se um estudo empírico comparativo das cadeias produtivas de FLV brasileira e holandesa. A cadeia holandesa encontra-se em uma fase mais desenvolvida que a brasileira, apresentando sistemas de classificação e padrões efetivos para os produtos e ótima estrutura de distribuição, enquanto, no Brasil, a cadeia produtiva de FLV encontra-se ainda no estágio de implementação de padrões e classificações. Na Holanda, tal fase ocorreu algumas décadas atrás, sendo que as cooperativas de produtores em conjunto com o Estado foram os agentes promotores do processo.

Apesar de encontrar-se em estágio anterior, a cadeia produtiva brasileira de FLV vem evoluindo nos últimos anos na mesma direção das cadeias internacionais, seguindo a tendência à concentração e do aumento do poder de barganha das grandes redes varejistas modernas na distribuição de produtos hortícolas. Observa-se também a elevação das relações diretas entre varejistas e produtores que visam o aumento da eficiência e a redução dos custos e que, simultaneamente enfraquecem o setor atacadista e melhoram a coordenação vertical da cadeia.

A tese mostra que a capacidade adaptativa do ambiente institucional de cada país, frente às mudanças do padrão competitivo, constituiu um fator de diferenciação da eficiência coordenativa da cadeia produtiva. O estabelecimento de instrumentos de controle e monitoração eficientes ao longo do século passado favoreceu o desenvolvimento da cadeia produtiva holandesa, sendo um fator essencial para a rápida capacidade de resposta do setor.

Enquanto o Estado holandês conta com a reputação de tornar crível qualquer ameaça de punição, pela utilização de mecanismos de controle e 
monitoramento eficientes das ações dos agentes, o Estado brasileiro apresenta a falta de capacidade de punir efetivamente os agentes, criando um efeito reputação inverso ao holandês, que estimula o aparecimento constante do comportamento oportunista.

Ao fornecer credibilidade tanto aos agentes privados implementadores dos padrões e classificações quanto aos sistemas de monitoramento e controle do Estado, a reputação torna-se um fator de extrema importância para os ganhos de produtividade nas cadeias produtivas. O esforço para preservação da reputação inibe o comportamento oportunista ao estabelecer punições e sanções críveis.

Somente com a inversão do efeito reputação, a cadeia produtiva de FLV brasileira conseguirá atingir o nível de organização e eficiência encontrada nos países desenvolvidos. Assim, cabe ao Estado brasileiro adotar uma postura reguladora mais forte, visando criar um ambiente institucional favorável ao desenvolvimento do setor.

Apesar do diferente estágio de desenvolvimento dos sistemas de padronização e classificação na cadeia produtiva de FLV nos dois países, em ambos, o atual sistema de coordenação baseado em estruturas de governança de mercado (leilão ou spot) vem sendo substituído pela coordenação estrita baseada em formas híbridas de governança, como descrito em Williamson (1991). Observa-se que a forma de mercado não consegue atender a nova demanda por produtos de qualidade diferenciada com baixo custo transação, exigindo o desenvolvimento de sistemas estritamente coordenados entre os agentes. Entretanto, o aparato institucional desenvolvido na Holanda ao longo das últimas décadas representa uma vantagem comparativa ao fornecer maior capacidade adaptativa aos produtores frente às mudanças do ambiente institucional, constituindo em fator de diferenciação da eficiência coordenativa da cadeia produtiva.

A presente tese fornece uma primeira visão das complexas interações existentes entre os agentes da cadeia produtiva de FLV. Ao descrever práticas comerciais, novas estratégias adotadas e indicar tendências futuras, a tese fornece um ponto de partida para o desenvolvimento de novas pesquisas. A 
necessidade de dados empíricos relacionados ao formato dos contratos estabelecidos entre os agentes se faz necessária para tornar mais claro o processo de transformação do setor de FLV. Entretanto, a capacidade de obtenção de informações a respeito do teor dos contratos tem-se mostrado limitada, em razão dos agentes as considerarem estratégicas. 


\section{BIBLIOGRAFIA}

AKERLOF, G. A. "The market for lemons: quality uncertainty and the market mechanism". Quarterly Journal of Economics, 84: 488-500,1970.

ALCHIAN, A. A. Some economics property. Santa Monica, Rand Corporation, 1961.

ALCHIAN, A. A. e DEMSETZ, H. "Production, information costs, and economic organization". American Economic Review, 62:777-795,1972.

ARROW, K. J. "Moral hazard". In ARROW, K.J., The Economics of Information. Harvard University Press, 1968.

ARROW, K. J. "The organization of economic activity: issues pertinent to the choice of market versus nonmarket allocation." In The analysis and evaluation of public expenditure, vol.1:59-73. Washington, DC, 1969.

ARROW, K.J. "The economics of agency". In Pratt, J.W e ZECKHAUSER, R.J., Principal and agents: the structure of business. Havard Business Scholl Press, 1985.

AXELROD, R. The evolution of cooperation. Nova York: Basic Books, 1984.

AXELROD, R. The Complexity of Cooperation: Agent-Based Models of Competition and Collaboration, Princeton: Princeton University Press, 1997.

AZEVEDO, P.F. Integração vertical e barganha. Tese de Doutorado em Economia da Faculdade de Economia, Administração e Contabilidade. São Paulo, 1996.

AZEVEDO, P.F e SILVA, V.L.S. "Contractual mix analysis in the brazilian franchising". V Annual Conference of International Society for New Institutional Economics, Estados Unidos, 2001.

BAGNARA, G. L. Brand name and added value in horticultural products: analysis of consumer perception. Instituto Sperimentale per la frutticoltura. Itália, 1996.

BAINES, R.N. e DAVIS, W.P. "Food quality assurance, public perceptions and international benchmarks". In Loader, R.J., HENSON, S.J. e TRAIL, W.B. 
(edit.), Globalization of the food industry: policy implications. University of Reading, pg.:109-124, 1997.

BARBER, N. Food for the World. Evans Brothers Ltd., London, 1990.

BARKEMA,A. e DRABENSTOTT,M. "Re-Defining the Role of Market Institutions and Government". Proceedings of the $2^{\circ}$ International Conference on Chain Management in Agri- and Food Business. Department of Management Studies. Wageningen Agricultural University, Holanda, 1996.

BARNARD, C. The functions of the executive. Cambrigde, MA: Harvard University Press, 1938.

BARZEL, Y. "Measurement cost and the organization of markets". Journal of Law and Economics, vol. XXV, pg. 27-48, 1982.

BARZEL, Y. Economic analysis of property rights. Cambridge University Press: Cambridge, 1989.

BATALHA, M. Gestão agroindustrial. Atlas, 1997.

BELIK, W. "Mecanismos de coordenação na distribuição de alimentos no Brasil". In BELIK, W. e MALUF, R. S. (edit.), Abastecimento e Segurança Alimentar. Campinas, SP: IE/UNICAMP, 2000.

BELIK, W., SANTOS, R.R. e GREEN, R. "Food retailing, quality signals and the consumer defense". XI IAMA World Food and Agribusiness Congress, Sidney, Australia, 2001.

BOCCALETTI, S. "Signaling quality of food products with designations of origin: advantages and limitations". X IAMA World Food and Agribusiness Congress, Chicago, Estados Unidos, 2000.

BROUSSEAU, E. e CODRON, J.M. "The hybridization of governance structures: supplying French supermarkets with off-season fruit". SFER Congress "Modern Food Retailing", Montpellier-France, 1997.

BROUSSEAU, E. e CODRON, J.M. "The combination of governance structures: supplying french supermarkets with off-season fruit". INRA, Montpellier, França, 2000.

BROUSSEAU, E. e FARES, M. "The incomplete contract theory and the new institutional economics approaches to contract: substitutes or complements?" 
In MÉNARD, C. (ed.), Institutions, contracts, organizations, perspectives from new institutional economics. Edward Elgar Pub., pg.: 399-421, 2000.

CARLTON, D. "Vertical integration in competitive markets under uncertainty". Journal of Industrial Economics, V. 27, pp. 189-209, 1979.

CASWELL, J. A., BREDAHL, M.E. e HOOKER, N. H. "How quality metasystems are affecting the food industry". Review of Agricultural Economics, 20(2):pg. 547-557, 1998.

CHEUNG, S. "On the new institutional economics". In CHEUNG, S. et al., Contract economics, pg.: 48-75, 1990.

CHURCHUMANN, C.W. Introdução à teoria dos sistemas. Petrópolis: Vozes, 1972.

COASE, R. "The nature of the firm". In COASE, R., The firm, the market, and the Law, Chicago: University of Chicago Press, 1988.

COASE, R. "The federal communications commission". Journal of Law and Economics, 2:1-40, 1957.

COASE, R. The firm, the market and the law, Chicago, University of Chicago Press, 1988.

CODRON, J.M., STERNS, J. A. e REARDON, T. "Consumer preferences, experience and credence issues and their strategic implications for French an US fresh produce sectors". X IAMA World Food and Agribusiness Congress, Chicago, Estados Unidos, 2000.

COMMONS, J.R. "Law and economics". Yale Law Journal, 34:371-382, 1924

COMMONS, J.R. Institutional economics. Madison, WI: University of Wisconsin Press, 1934.

DAVID, P.A. e GREENSTEIN, S. "The economics of compatibility standards: an introduction to recent research". Economic of Innovation and New Technology, vol.1: 3-41, 1990.

DAVIS, J. H. e GOLDBERG, R.A. A concept of agribusiness. Harvard University, 1957. 
DAVIS, L.E. e NORTH, D. Institutional change and american economic growth. Cambridge: Cambridge University Press, 1971.

DE ALESSI, L. "The economics of property rights: a review of the evidence". Research in Law and Economics, 1-47, 1980.

DEMSETZ, H. "Toward a theory of property rights". American Economic Review, 57:347-359, 1967.

DIMITRI, C. "Integration, coordination, and concentration in the fresh, fruit and vegetable industry". USDA, FTS-285: 23-31, 1999.

DOSI, G. Technical change and industrial transformation. McMillan Press, 1984.

EGGERTSSON, T. Economic Behavior and Institutions. Cambridge University Press: Cambridge, 1990.

FAMA, E. F. "Agency problems and the theory of the firm". Journal of Political Economy, 88: 288-307, 1980.

FAMA, E.F. e JENSEN, M.C. "Separation of ownership and control". Journal of Law and Economics, 26: 301-326, 1983.

FARINA, E.M.M.Q. "Padronização em sistemas agroindustriais". In: Cinco ensaios sobre qualidade em alimentos. Seminário Internacional PENSA, 1999.

FARINA, E.M.M.Q. e MACHADO, E.L. "Regulamentação governamental e estratégias de negócio no mercado brasileiro de frutas e legumes frescos". In BELIK, W. e MALUF, R. S. (edit.), Abastecimento e Segurança Alimentar. Campinas, SP: IE/UNICAMP, 2000.

FARINA, E.M.M.Q. e REARDON, T. "Agrifood grades and standards in the extented Mercosur: their role in the changing agrifood system". American Journal of Agricultural Economics, 82(5): pg. 1170-1176, 2000.

FARINA, E.M.M.Q., AZEVEDO, P.F. e SAES, M.S.M. Competitividade: mercado, estado e organização. Editora Singular, 1997.

FARINA, E.M.M.Q. e ZYLBERSZTAJN, D. Organização das cadeias agroindustriais de alimentos. Série Estudos Temáticos 006/92. PENSA, FEAUSP, 1992. 
FARINA, E.M.M.Q. e ZYLBERSZTAJN, D. Agribusiness: coordenação das relações de conflito e cooperação. Série Estudos Temáticos 005/93. PENSA, FEA-USP, 1993.

FARINA, E.M.M.Q. e ZYLBERSZTAJN, D. "Competitividade e organização das cadeias agro-industriais". IICA - Instituto Interamericano de Cooperação para a Agricultura, 1994.

FERGUSON, C. e CARMAN, H. "Kiwifruit and the lemon problem: do minimum quality standards work? "IX IAMA World Food and Agribusiness Congress, Florença, Itália, 1999.

FOOD AND AGRICULTURAL ORGANIZATION - FAO (1996), Production Statistics, disponível em www.fao.org em 10/02/2001, 1996.

FORAY, D. "Standard de référence, coûts de transaction et économie de la qualité: un quadre dánalyse" In: NICOLAS, F. \& E. VALCESCHINI (edit.), AgroAlimentaire: une économie de la qualité. INRA Editions Economica, 1994.

FUDENBERG, D. e TIROLE, J. Game Theory. Cambridge: MIT Press, 1991.

FUROBOTN, E. G. e PEJOVUCH, S. "Property rights and economic theory: a survey of recent literature". Journal of Economic Literature, 10:1137-1162, 1972.

FUROBOTN, E. G. e PEJOVUCH, S. The economics of property rights. Cambridge (MA), Ballinger, 1974.

FURUBOTN, E. G. e RICHTER, R. The new institutional economics: an assessment. College Station, Texas A\&M Press, 1991.

GALLINI, N. T. e LUTZ, N. A. "Dual distribution and royalty fees in franchising". Journal of Law, Economics, \& Organization, 8, 471-501, 1992.

GIOVANNUCCI, D. e REARDON, T. "Understanding grades and standards and how to apply them". In GIOVANNUCCI, D., A Guide to Developing Agricultural Markets and Agro-enterprises. Michigan State University, 2001.

GOLBERG, R. A. Agribusiness coordination: a systems approach to the wheat, soybean, and Florida orange economies. Harvard University, 1968.

GREEN, R.H. "Principales tendencias de la restructuracion del sistema alimentario mundial”, Working Paper, INRA, Paris, 1993. 
GROSSMAN, S. e HART, O. "The cost and benefits of ownership: a theory of vertical and lateral integration". Journal of Political Economy, 94:691-719, 1986.

GROSSMAN, S. e PERRY, M. "Perfect Sequential Equilibrium". Journal of Economic Theory, XXXIX, 97-119, 1986.

GRYNA, F.M. "Relações com o fornecedor." In: JURAN, J.M., et al. Controle de qualidade: handbook. Makron Books, vol.3, cap.15, 1992.

HART, O. e HOLMSTROM, B. "The theory of contracts". In BEWLEY, T. (edit.). Advances in economic theory, fifth world congress. Cambridge University Press, 1987.

HAYEK, F. "The use of knowledge in society". American Economic Review, 35: 519-530, 1945.

HOUTHAKKER, H. "Compensated changes in quantities and qualities consumed". Review of Economic Studies, vol.:19:155-164, 1952.

IFIC. Backgrounder - Agriculture \& Food Production. Disponível na Internet, Aug./1998, http://ificinfo.health.org/backgrnd/bkgr12.htm, 1998

INSTITUTO BRASILEIRO DE GEOGRAFIA E ESTATÍSTICA (IBGE). Pesquisa de Orçamento Familiar. IBGE, Rio de Janeiro, 1987/1988 e 1995/1996.

JACQUEMIN, A. "Sélection et pouvoir dans la nouvelle economie industrielle". Economica, 1985.

JENSEN, M.C. "Agency costs of free cash flow, corporate finance, and takeover". American Economic Review, 76: 323-329, 1986.

JENSEN, M.C. e MECKLING, W.H. "Theory of the firm: managerial behavior, agency costs, and ownership structure". Journal of Financial Economics, 3: 305-360, 1976.

JONES, E. e HILL, L. D. "Re-engineering marketing policies in food and agriculture: issues and alternatives for grain grading policies". In PADBERG, D.L. (ed.), Re-engineering marketing policies for food and agriculture. FAMC, College Station: Texas A\&M University, 1994.

JOSKOW, P. "The new institutional economics: alternatives approaches". Journal of Institutional and Theoretical Economics, v.151,n¹, pg.:248-259, 1995. 
KASPER, J.F.P. Produtividade e gerenciamento de operações na empresa supermercadista. São Paulo: Associação Brasileira de Supermercados, 1991.

KINDLEBERGER, C. P. "Standards as public, collective and private goods." KYKLOS -International review for social sciences 36:377-396, 1983.

KLEIN, B. "Contracts and incentives: the role of contracts terms in assuring performance". In: WERIN, L. e WIJKANDER, H., Contracts economics. Blackwell, Oxford, 1992.

KLEIN, B. e LEFFLER, K. B. "The role of market forces in assuring contractual performance”. Journal of Political Economy, vol.89, n41, 1981.

KLEIN, B. e SAFT, L. "The law and economics of franchise tying contracts". Journal of Law and Economics, vol. XXVII: 345-361, 1985.

KLEIN, B., CRAWFORD, R. e ALCHIAN, A. "Vertical integration, appropriable rents, and the competitive contracting process". Journal of Law and Economics, 21: 297-326, 1978.

KLEIN, D. B. "Reputations: studies in the voluntary elicitation of good conduct". Ann Arbor, MI: University of Michigan Press, 1997.

KLEIN, P.G. "New institutional economics". Working Paper of University of Georgia, 1998.

KNIGHT, F. H. "Review of melville j. herskovits, economic anthropology". Journal of Political Economy, 49:247-258, 1941.

KOOPMANS, J. Three essays on the state of economic science. Nova York, McGraw-Hill, 1957.

KREPS, D. M. "Company culture and economic theory". In ALT, J. e SHEPSLE (eds). Perspectives on positive political economy, Cambridge University Press, 1990.

KREPS, D. M. e WILSON, R. "Reputations and Imperfect Information". Journal of Economic Theory 27:253-279, 1982.

KREPS, D. M., MILGROM, P., ROBERTS, J. e WILSON, R. "Rational Cooperation in the Finitely Repeated Prisoner's Dilemma". Journal of Economic theory, 27: 245-52, 1982. 
KÜHL, R. W. e DRESCHER, K. "The Impact of Product Quality on Vertical Integration in the Agro-Food-Sector". II International Conference on Chain Management in Agri and Food Business, Wageningen Agricultural University, Holanda, 1996.

LAFFONT, J.J. e MASKIN, E. "A differential approach to dominant strategy mechanism". Econometrica, Vol. 48, № 6, pp. 1507-1521, 1980.

LAFONTAINE, F. \& SHAW, K. L. "Targeting managerial control: evidence from franchising". International Society for New Institutional Economics Conference, Washington, D.C, 1999.

LANCASTER, K. "A new approach to consumer theory". Journal of Political economy, vol.:74: 132-157, 1966.

LAZZAROTTO, N. F. "Estudos sobre o mercado de certificações de qualidade em alimentos no brasil". V SEMEAD, FEA-USP, 2001.

LELAND, H. E. "Quacks, lemons, and licensing: a theory of minimum quality standards". Journal of Political Economy 87, pg. 1328-1346, 1979.

LIMA FILHO, D.O. Valor percebido e o comportamento do consumidor de supermercado: um estudo exploratório em uma média cidade brasileira. Tese de Doutorado em Administração. FGV-SP, 1999.

LOADER, R. "Transaction costs and relationships in agri-food system". In: TRIENEKENS, J.H. e ZUURBIER, P. (edit.), Proceedings of II International Conference on Chain Management in Agri- and Food Business. Wageningen Agricultural University, pg.: 417-429, 1996.

MACHADO, R.T.M. Rastreabilidade, tecnologia da informação e coordenação de sistemas agroindustriais. Tese de Doutorado em Administração da FEA-USP. São Paulo, 2000.

MACNEIL, I.R. "The many futures of contracts". Working Paper. Southem California Review, 47: 691-816, 1974.

MACNEIL, I.R. "Contracts: adjustments of long-term economic relations under classical, neoclassical and relational contract law". Northwestem University Law Review, 72:854-906, 1978. 
MARTIN, H.M e HUGHES, D.R "Food chain integration and Dutch competitiveness". Proceedings of III IAMA Symposium: Managing in a Global Economy, São Francisco, California, Estados Unidos, 1993.

MAS-COLELL, A., WHINSTON M. D. e GREEN, J.R. Microeconomic Theory. Oxford University Press, New York, 1995.

MASTEN, S. E. "Transaction cost economics and the organization of agricultural transactions". World Food Systems Project Symposium. Chicago, 1718/10/91, 1991.

McLAUGHLIN, E. e PEROSIO, D. "Fresh fruit and vegetable procurement dynamics: the role of supermarket buyer". Cornell Food Industry Management Program Working Paper, 1994.

MÉNARD, C. L'economie des organisations. Repères La Découverte, 1995.

MÉNARD, C. "Of clusters, hybrids and other strange forms. The case of the French poultry industry". Journal of Institutional and Theoretical Economics 152/1: 151-183, 1996.

MEZZOMO, C.P.L. Sistema agroindustrial das olerícolas congeladas: a coordenação entre o olericultor e a agroindustria do congelamento. Dissertação de Mestrado. Universidade Federal de Lavras, 1997.

MILGROM, P. e ROBERTS, J. "Predation, reputation and entry deterrence". Journal of Economic Theory, XXVII, 27:280-312, 1982.

MILGROM, P. R. e ROBERTS, J. Economics, organizations, and management. Prentice-Hall, New Jersey, 1992.

MORVAN, Y. "Filière de production, in fondaments d'economie industrielle". Economica, 1985.

NASSAR, A.M. "Certificação no agronegócio". In: Cinco ensaios sobre qualidade em alimentos. Seminário Internacional PENSA, 1999.

NASSAR, A.M. e BOTELHO, R.V. "Análise das transações no sistema agroindustrial da batata". Caderno de Pesquisas em Administração,vol.1, n`8, pg.:27-39, 1999. 
NELSON, P. "Information and consumer behavior". Journal of Political Economy, 78: 311-329, 1970.

NORTH, D. "The new institutional economics". Journal of Theoretical and Institutional Economics, 142:230-237, 1986.

NORTH, D. Institutions, institutional change and economic performance. Cambridge: Cambridge University Press, 1990.

NORTH, D. "Institutions". Journal of Economic Perspectives, 5(1): 97-112, 1991.

NORTH, D. Custo de transação, instituições e desempenho econômico. Rio de Janeiro, Instituto Liberal, 1994.

OECD. "Vertical coordination in the fruit and vegetable sector: implications for existing market institutions and policy instruments". Working paper, 1997.

PEKKARINEV, M. "World Food Consumption Patterns". In : RECHCIGL JR., M.(Ed.). Man, Food and Nutrition, CRC Press Inc., Ohio, Estados Unidos, 1975.

PERI, C. e GAETA, D. "Designations of origin and industry certification as means of valorizing agricultural food products". In: VINCI, S. (Coord.). The European agro-food system and the challenge of global competition. Roma, ISMEA, Junho, 59-68, 1999.

PHILIPPE, F. E SAUVÉE, L. "Coordination efficiency: proposals for a framework. An illustration with the fresh tomato sector in France". International Conference: Vertical Relationships and Coordination in the Food System, Piacenza, Italy, June 12-13, 1997.

QSPO. "Analytical framework for quality signal and governance structures". Não publicado. European Project, 2000.

RAO, A. R. e MONROE, K.B. "The effect of price, brand name and store name on buyers perception of product quality: an integrative review". Journal of Marketing Research, 26, August, 1989

RASMUSEN, E. Games and information: an introduction to game theory. $2^{\mathrm{a} e d i c ̧ a ̃ o, ~ C a m b r i d g e, ~ M a s s . ~ B l a c k w e l l ~ P u b l i s h e r s, ~} 1994$.

REARDON, T., CODRON, J.M., BUSCH, L., BINGEN, J. e HARRIS, C. "Global change in agrifood grades and standards: agribusiness strategic responses 
in developing countries". International Food and Agribusiness Management Review, 2(3), 2001.

REARDON, T. e FARINA, E.M.M.Q. "The rise of private of food quality and safety standards: illustrations from Brazil". IAMA 2001 Food and Agribusiness Symposium. Sidney, Australia, 2001.

REVISTA FRUTAS \& LEGUMES. "Horti\&fruti padrão avança para todo o Brasil". Novembro. São Paulo, 2000.

RIORDAN, M. "What is vertical integration?" In: AOKI, M., GUSTAFSSON, B. e WILLIAMSON, O., The firm as a nexus of treaties. Londres: Sage, 1990.

RUBINSTEIN, A. "A bargaining model of incomplete information about preferences". Econometrica, LIII, 1151-1172, 1985.

SARTI, F. M. e MACHADO, E. L. "The influence of nutritional aspects in Brazilian fresh fruit and vegetable chain coordination". World Food and Agribusiness Congress (IAMA), Chicago (USA), 24-28/07/00: http://www.ifama.org (on line), 2000.

SCHOTTER, A. Economic theory of social institutions. Cambridge, Eng.: Cambridge University Press, 1981.

SCHWARTZ, A. "Legal theory and incomplete contracts". In WERIN, L. e WIJKANDER, H., Contracts economics, Blackwell, Oxford, 1992.

SHAPIRO, C. "Premiums for high quality products as returns to reputations". The Quarterly Journal of Economics. Novembro, pg.:661-679, 1983.

SIMON, H. Models of man. New York: Wiley, 1957.

SIMON, H. Administrative behavior. New York: Macmillan, 1961.

SIMON, H. "Theories of bounded rationality". In MCGUIRE, C.B. e RADNER, R., Decision and organization. Nova York: American Elsevier, 161176, 1972.

SIMON, H. "Rationality as process and as product of thought". American Economic Review, 68:1-16, 1978.

SOUSA, E.L., CANZIANI, J.R. e GALAN, V.B. Padronização de produto e coordenação de sistemas agroindustrias: o caso do SAG do tomate no Estado de São Paulo. Não publicado, 2000. 
SOUZA, R. A. M et al. "Comercialização hortícola: análise de alguns setores do mercado varejista de São Paulo". Informações Econômicas, SP, v.28, n.10, IEA, pg.: 7-23, 1998.

SPENCE, A. M. "Job market signaling". Quarterly Journal of Economics 87: 355-374, 1973.

SPERS, E. E. "Qualidade e segurança em alimentos". In ZYLBERSZTAJN, D. e NEVES, M. F.(edit.), Economia e gestão dos negócios agroalimentares. Editora Pioneira, São Paulo, 2000.

SPILLER, P.T. e ZELNER, B.A. "Product Complementarities, Capabilities and Governance: A Dynamic Transaction Cost Perspective". Institutional and Corporate Change, Vol. 6, Oxford University Press, 1997.

SPORLEDER, T. L., FULLER, S. e HAHN, D.E. "Strategic alliances as interfirm vertical coordination in the global food system". American Agricultural Economics Association, August 2-5, 1998.

SPORLEDER, T. L. e GOLDSMITH, P. D. "Alternative firm strategies for signaling quality in food system". The Ohio State University, Working paper AEDEWP-0017-01, 2001.

STIGLER, G. "The economics of information". Journal of Political Economy 69, 1961.

THEIL, H. "Qualities, prices and budget enquiries". Review of Economic Studies, vol:19: 129-147, 1952.

TIROLE, J. The theory of industrial organization. The MIT Press, 1988.

TRIENEKENS, J. e BEULENS, A. "The implications of EU food safety legislation and consumer demands on supply chain information systems". Management Studies Group. Wageningen University, Holanda, 2000.

VARIAN, H.R. Microeconomia: princípios básicos. Editora Campos, 1994 WILLIAMSON, O.E. Markets and hierarchies: analysis and antitrust implications. New York, Free Press, 1975.

WILLIAMSON, O.E. The economic institutions of capitalism: firms, markets, relational contracting. New York: The New York Free Press, 1985. 
WILLIAMSON, O.E. "Comparative economic organization: the analysis of discrete structural alternatives". Administrative Science Quarterly, 36: 269-296, 1991.

WILLIAMSON, O.E. "Transaction cost economics and organization theory". In WILLIAMSON, O.E. The mechanisms of governance. New York: Oxford University Press, pg.: 54-87, 1996.

WILLIAMSON, O.E. The mechanisms of governance. Oxford University Press, 1996.

ZUURBIER, P. "Market structure and vertical coordination". In: TRIENEKENS, J.H. e ZUURBIER, P. (edit.), Proceedings of $2^{\text {nd }}$ International Conference on Chain Management in Agri- and Food Business. Wageningen Agricultural University, pg.: 307-322, 1996.

ZUURBIER, P. "Supply chain management in the fruit and vegetable industry". Wageningen Agricultural University, Holanda, 1998.

ZYLBERSZTAJN, D. Estruturas de governança e coordenação do agribusiness: uma aplicação da nova economia institucional. Tese de Livre Docência em Administração, FEA-USP, 1995.

ZYLBERSZTAJN, D. "Entre o mercado e a hierarquia: análise de casos de quebra contratual no agribusiness". Série Estudos Temáticos 003/96. PENSA, FEA-USP, 1996.

ZYLBERSZTAJN, D. "Papel do estado nos agronegócios: mecanismos para a indução da qualidade nos alimentos". IV SEMEAD, FEA-USP, 1999.

ZYLBERSZTAJN, D. "A Organização Ética: um ensaio sobre as relações entre ambiente econômico e o comportamento das organizações". PENSA, Universidade de São Paulo, 2000.

ZYLBERSZTAJN, D. e FARINA, E. "Strictly coordinated supply systems". I Simpósio de Sistemas Agroindustriais. FEARP-USP, 1997.

ZYLBERSZTAJN, D. e FARINA, E. "Supply chain management: recent developments and applicability of the concept". II Annual Conference of International Society for New Institutional Economics. Paris, 1998. 
ZYLBERSZTAJN, D., JANK, M. S., KOOL, M. e SLUYS, T. "Holanda: um modelo de agribusiness". Série Estudos Temáticos 002/92. PENSA, FEA-USP, 1992.

ZYLBERSZTAJN, D., JANK, M. S., NASSAR, A.M. "A property rights approach to (lack of) trade liberalization”. Working Paper. Não Publicado, 2002. 